\title{
Metamorphism of the
}

Belt Series in the

Elk River-Clarkia Area

Idaho

GEOLOGIGAL SURVEY PROFESSIONAL PAPER 344-G

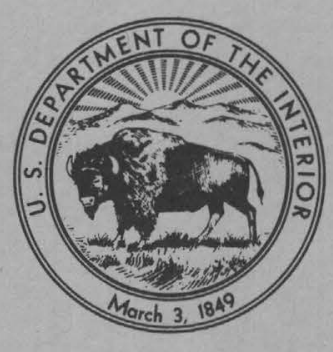





\section{Metamorphism of the}

Belt Series in the

Elk River-Clarkia Area

\section{Idaho}

By ANNA HIETANEN

METAMORPHIC AND IGNEOUS ROCKS ALONG THE NORTHWEST BORDER ZONE OF THE IDAHO BATHOLITH

GEOLOGICAL SURVEY PROFESSIONAL PAPER 344-C

Petrologic study of the

moderately and highly metamorphosed

equivalents of the Belt series

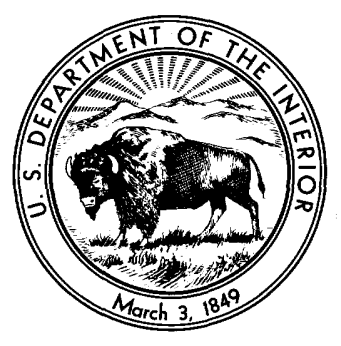

UNITED STATES GOVERNMENT PRINTING OFFICE, WASHINGTON : 1963 


\section{UNITED STATES DEPARTMENT OF THE INTERIOR \\ STEWART L. UDALL, Secretary}

\section{GEOLOGIGAL SURVEY}

Thomas B. Nolan, Director

For sale by the Superintendent of Documents, U.S. Government Printing Office Washington, D.C., 20402 


\section{CONTENTS}

Abstract.

Introduction . . . . . . .

Area studied

Fieldwork

Specimen and locality numbers.

Classification of the rocks.

Belt series.

Prichard formation

Distribution and lithology

Stratigraphy

Petrography . . . . . .

Schist.

Gneiss

Quartzite.

Garnet amphibolite

Revett quartzite

Distribution and lithology

Stratigraphic sequence and thickness..........

Petrographic description.

St. Regis formation . . .

Distribution and lithology

Petrography . . . . . .

Wallace formation . .

Distribution and lithology . .

Stratigraphy and correlation

Petrography

Schist

Thin-bedded biotite and diopside or hornblende quartzite and gneiss . . .

Diopside gneiss

White granular quartzite

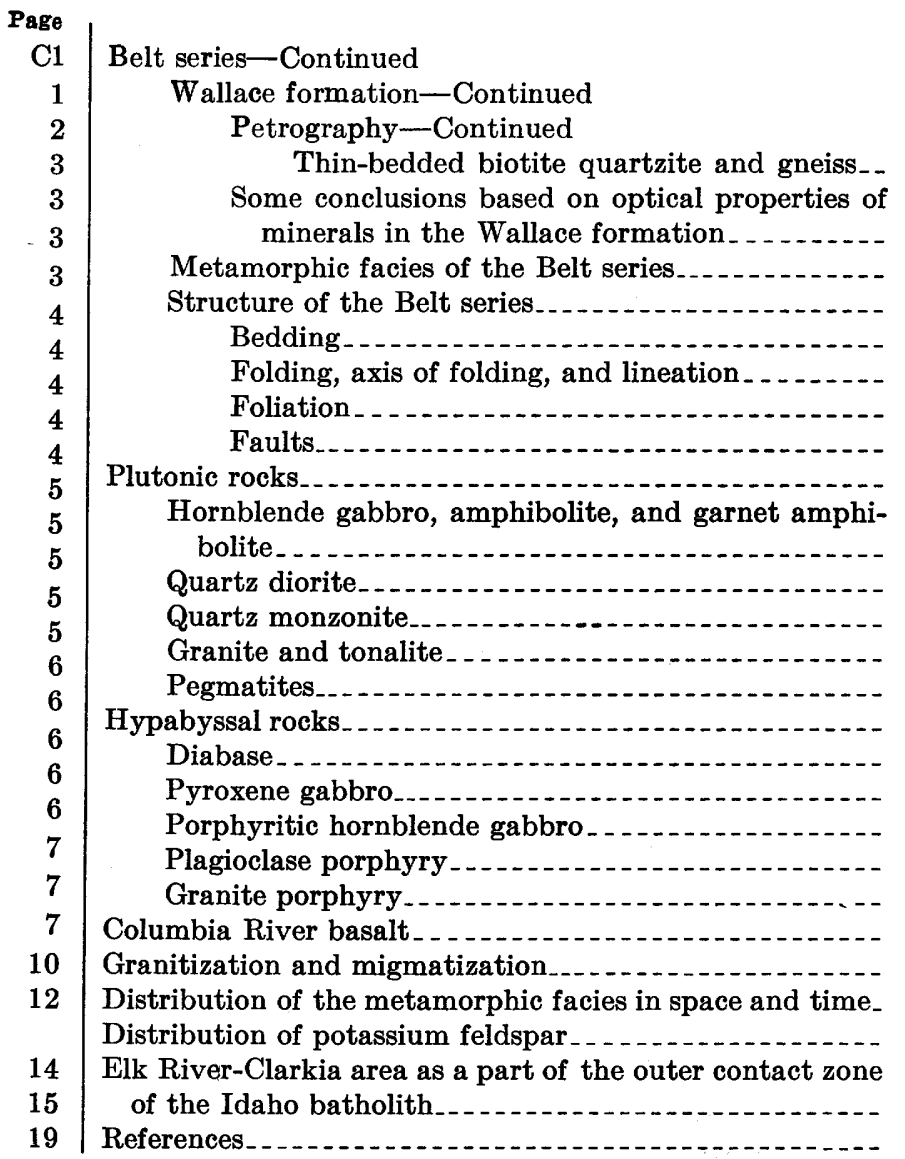

\section{ILLUSTRATIONS}

\section{[Plate is in pocket]}

1. Index map of northern Idaho

2. A cross section through the upper quartzite-gneiss unit of the Wallace formation near Bloom Meadows. -

3. Bedding in thin-bedded biotite and diopside gneiss

$4 A, B$. Photomicrographs of schist of the Wallace formation in the northern part of the area

$5 A, B$. Photomicrographs of a sillimanite schist and a quartzite layer in schist of the Wallace formation......

6. Camera lucida drawing of muscovite and kyanite in garnet-kyanite schist

$7 A, B$. Thin-bedded biotite gneiss and diopside gneiss of the Wallace formation

8. Camera lucida drawing of biotite laminae in diopside gneiss

$9 A, B$. Photomicrographs of biotite laminae and tremolite-diposide gneiss in the Wallace formation . . . . . .

10. Camera lucida drawing of diopside gneiss along East Fork of Potlatch Creek

11. Camera lucida drawing of diopside quartzite south of Elk River

12. Camera lucida drawing of diopside-plagioclase gneiss along North Fork of the Clearwater River 
Figdre $13 A, B$. Photomicrographs of white granular quartzite in the Wallace formation $14 A, B$. Photomicrograph of biotite gneiss and photograph of round scapolite grains in biotite gneiss in the Wallace formation

$15 A, B$. Photograph and photomicrograph of scapolite-bearing layer in biotite gneiss of the Wallace formation

16. ACFK diagram for the rocks of the biotite-almandite subfacies of the epidote-amphibolite facies........

17. ACFK diagram for the rocks of the staurolite-kyanite subfacies of the epidote-amphibolite facies . . . . ...

18. ACFK diagram for the rocks of the sillimanite-muscovite subfacies of the amphibolite facies

19. Small overturned folds and a thrust plane 3 miles southeast of Elk River.

20. An overturned syncline in the Prichard formation along West Stony Creek

21. A small overthrust in diopside gneiss of the Wallace formation 2 miles east of Jackson Mountain .....

22. A contact of quartz diorite and the diopside gneiss of the Wallace formation

$23 A, B$. Photomicrographs of quartz diorite and granodiorite gneiss

$24 A, B$. Photomicrographs of quartz monzonite and porphyritic hornblende gabbro

25. Contacts between schist and granite

26. Pegmatitic veins cut by granite veins in biotite gneiss

27 A, B. Photomicrographs of plagioclase porphyry and Columbia River basalt

28. Granite porphyry dike cut by pegmatite.

29. Remnants of kyanite-sillimanite-biotote-muscovite schist in fine-grained granite

30. Hypothetical curve for the temperature of recrystallization in various metamorphic facies

\section{TABLES}

$T_{A B L E}$ 1. Generalized section of the lower quartzite-gneiss unit of the Wallace formation, exposed along Merry Creek in secs. 23 and 14, T. 43 N., R. 2 E

2. Generalized section of the lower quartzite-gneiss unit of the Wallace formation along the St. Maries River, secs. 11, 14, and 23, T. 42 N., R. 2 E

3. Generalized section of the upper quartzite-gneiss unit of the Wallace formation along Mallory Creek and East Fork of Potlatch Creek, west of the mouth of Mallory Creek

4. Measured mode in volume percentages of various layers of diopside gneiss along East Fork of Potlatch Creek and south of Elk River.

5. Estimated volume percentage of major constituents in typical layers of the lower quartzite-gneiss unit of the Wallace formation.

6. Estimated volume percentage of major constituents in typical layers of the upper quartzite-gneiss unit of the Wallace formation

7. Index of refraction of biotite in various layers of the Wallace formation

8. Optical properties of minerals in the amphibole-and diopside-bearing gneiss of the Wallace formation...-

9. Stability ranges of critical minerals in schists and calcareous gneisses, northwest of the Idaho batholith....- 


\title{
METAMORPHIC AND IGNEOUS ROCKS ALONG THE NORTHWEST BORDER ZONE OF THE IDAHO BATHOLITH
}

\section{METAMORPHISM OF THE BELT SERIES IN THE ELK RIVER-GLARKIA AREA, IDAHO}

\author{
By Anna Hietanen
}

\begin{abstract}
The Elk River-Clarkia area lies from 10 to 35 miles northwest of the Idaho batholith in a zone of moderately to highly metamorphosed sedimentary rocks of the Precambrian Belt series. The Prichard formation, which is the oldest unit in the Belt series, covers the northeastern part of the area and consists mainly of garnet-mica schist with a minor amount of quartzite. It is separated by a fault zone from the younger formations. The massive Revett quartzite is fragmentarily exposed along and near this fault zone and is overlain by a fairly thin layer of schist of the St. Regis formation. The youngest formation, the Wallace, covers the western and southern part of the area. It consists of aluminous schist and interbedded calcareous gneiss and quartzite. The Burke formation, which should occur between the Prichard and Revett formations, could not be identified in this area.
\end{abstract}

Two large and a number of small bodies of igneous rocks occur in the metasedimentary series. One of the large bodies is quartz diorite and the other is quartz monzonite. The composition of the small bodies ranges from gabbro to quartz diorite, quartz monzonite, and granite.

The grade of metamorphism of the Belt series increases gradually from northwest to southeast parallel to the major structural trend and suggests that the metamorphism is related to the intrusion of the Idaho batholith, the nearest outcrops of which are exposed about 10 miles southeast of the area under discussion. The critical mineral assemblage in the schists in the northern part is almandine-muscovitebiotite-quartz; in the calcareous layers of the gneisses the common assemblage is homblende-biotite-epidote mineralsalbite-microcline-quartz with or without scapolite and calcite. These mineral assemblages are typical of the biotitealmandite subfacies of the epidote amphibolite facies. Toward the south, kyanite appears with staurolite in the aluminumrich layers of the garnet-mica schist and diopside becomes stable in the calcareous layers of the gneissic units. Oligoclase instead of albite occurs with the epidote minerals. Microcline abounds in many thin biotite-rich layers interbedded with diopside and biotite gneisses. These mineral associations suggest metamorphic temperatures of the staurolite-kyanite subfacies of the epidote amphibolite facies.

The occurrence of sillimanite instead of staurolite and kyanite in the schist in the southern part of the area suggests the sillimanite-muscovite subfacies of the amphibolite facies. Grossularite occurs with calcite in a few calcareous layers, but the assemblage diopside-biotite-plagioclase $\left(\mathrm{An}_{30}\right)$ is most common. Metamorphic temperatures are estimated to rise from $380^{\circ} \mathrm{C}$ in the northern border to $570^{\circ} \mathrm{C}$ in the southern border.

Contrary to the normal distribution of the potassium feldspar in the regionally metamorphosed area, microcline is rare or lacking in the gneisses of the southernmost part-that is, in the zone of highest grade of metamorphism. This lack of microcline can be either depositional or due to a later partial removal of potassium from a contact zone of the Idaho batholith about 20 miles wide. In the light of the regional geology the latter possibility seems more likely and would suggest that potassium was mobilized in a wider contact aureole than the other elements (calcium, aluminum, iron, and magnesium). It was removed from the inner contact aureole, which is the zone of metasomatic enrichment of basic components (Hietanen, 1962), and probably also from the southern part of the area under discussion, which part belongs to an outer contact aureole of the batholith. No other traces of regional metasomatism could be found in this outer zone.

\section{INTRODUCTION}

This report is a petrologic and structural study of the metamorphic and igneous rocks in an area outside of the immediate contact zone of the Idaho batholith. The area lies from 10 to 35 miles northwest of the batholith (fig. 1). In this outer zone, metasedimentary rocks belonging to the Precambrian Belt series show a moderate to high degree of metamorphism, but they show little if any of the kind of profound metasomatism that was found in the zone next to the batholith, where quartz is locally replaced by andesine and hornblende (Hietanen, 1962). However, some of the gneissic units have a definite and regular lateral change in composition parallel to the bedding.

The Belt series in the Coeur d'Alene district and in western Montana has been described as "a monotonous sequence of sombre-colored, rather fine-grained clastic rocks" (Ross, 1956, p. 687) consisting mainly of great thicknesses of quartzite and containing only insignificant amounts of carbonates and other normal miogeosynclinal sediments. In contrast, the corresponding depositional units in the present area were metamorphosed to distinctive rock types of varied mineralogy and composition, containing abundant kyanite, 


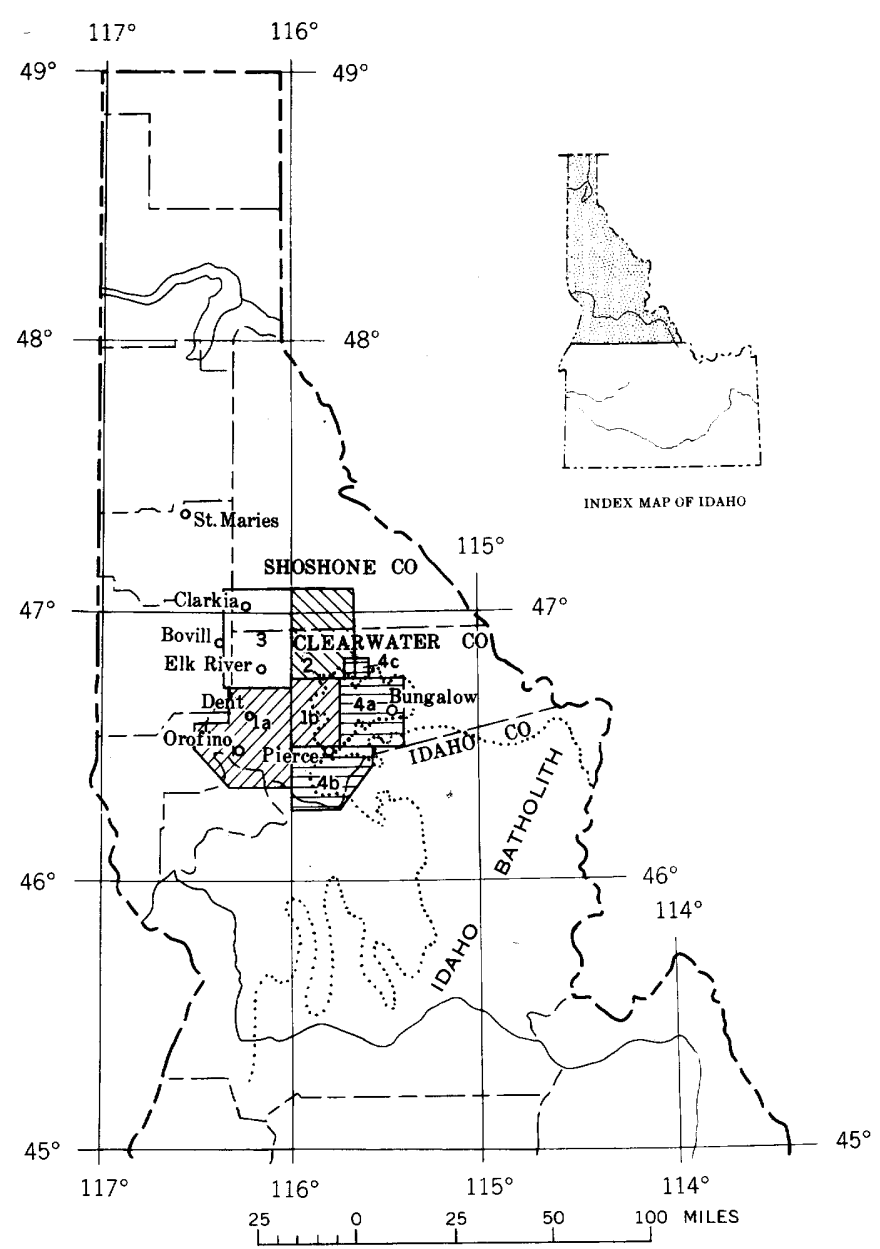

FigURD 1,-Index map of northern Idaho. 1a, Orofino, Dent, and Big Island areas; 1b, Headquarters quadrangle (Hietanen, 1962); 2, Boehls Butte quadrangle and vicinity (Hietanen, 1963) ; 3, Elk RiverClarkia area, this report; $4 \mathrm{a}$, Bungalow area; $4 \mathrm{~b}$, Pierce area; $4 \mathrm{c}$ Beaver Creek area. The dotted line shows the outline of the northern part of the Idaho batholith.

sillimanite, garnet, biotite, and muscovite in the original shaly layers (now coarse-grained schist) and much hornblende, diopside, tremolite, biotite, and calcite in the dolomitic sand layers (now fine- to mediumgrained gneiss). Only a few pure quartzite layers are interbedded with the schist and gneiss. In the gneissic units the variation in the amounts of the major constituents-quartz, plagioclase, microcline, diopside, hornblende, tremolite, and biotite-makes the layering distinct and gives rise to identifiable, fairly persistent subunits.

Distribution of potassium feldspar in some of these subunits shows a regular lateral variation and offers a special problem concerning its origin. Two possibilities are considered: that the variation in the amount of potassium feldspar is depositional, or that it is metasomatic. The field evidence favors the first possibility for the northern part of the area. Comparison with the earlier studies in the zone closest to the batholith (Hietanen, 1962) suggests that the lack of the potassium feldspar in the southern part may be due to the removal of potassium during metasomatic metamorphism.

\section{AREA STUDIED}

The area studied lies in the northwestern part of Clearwater County and the extreme southwestern part of Shoshone County, Idaho (fig. 1). It is bound by long $116^{\circ} 00^{\prime}$ and $116^{\circ} 20^{\prime} \mathrm{W}$. and lat $46^{\circ} 42^{\prime}$ and $47^{\circ} 05^{\prime}$ $\mathrm{N}$. and comprises 420 square miles. Orofino, Dent, and big Island areas and Headquarters quadrangle, and Boehls Butte quadrangle and vicinity were previously mapped by the author (Hietanen, 1962, 1963, respectively).

The area lies just east of the Columbia River Plateau and is characterized by deep stream valleys which are separated by narrow divides. The southern part of the area is drained southward to the North Fork of the Clearwater River, and the northern part northward to the St. Joe River mainly by the St. Maries River and its tributaries. The altitude of the stream valleys near Elk River is 2,900 feet and near Clarkia is 2,850 feet. The highest mountains rise 6,000 feet above sea level. The local relief ranges from 1,500 feet in the western part to 3,000 feet in the eastern part.

A good gravel road connects Clarkia and St. Maries, a town 20 miles to the northwest. Another gravel road leads from Clarkia to Bovill, a small logging town 18 miles to the south-southwest. Elk River is connected to Bovill by a gravel road and a 20-milelong dirt road leads from Elk River to Dent, on the North Fork of the Clearwater River 5 miles south of the area studied. Dent is in turn connected to Orofino and other points to the west. Narrow dirt roads lead eastward from Elk River and Clarkia to the Boehls Butte quadrangle. Many logging roads and dry season jeep roads (pl. 1) make the area fairly accessible. The mountain areas are crossed by a few trails, following mainly ridges and streams.

Most of the area is heavily timbered by white and yellow pine, fir, cedar, hemlock, spruce, and larch. Locally in the northeastern part, however, forest fires have destroyed virgin timber and a second growth of small- to medium-size trees has reforested only the drainage valleys and lower mountain slopes, the higher surfaces being covered by brush, grass, and scattered small trees. In all forested parts of the area the soil cover is thick and accordingly the outcrops are poor. 
FIELDWORK

Previous work has been restricted to reconnaissance by Anderson (1930), who recognized the Belt series covering most of the area, a granitic stock north of Elk River, and the Columbia River basalt south and southwest of this town.

Fieldwork for this report was done intermittently during the summers of 1952 to 1955 and 1957. The author was assisted in the field by Dorothy Rainsford and Cynthia Wilkin in 1952, by Katharine Wagner and Patty Newbold in 1953, and by Alice Vrbsky and Frances Gilbert in 1955.

As the main purpose was to study metamorphism, detailed mapping was not attempted. Rather, in all forested parts of the area, where soil cover is thick and bedrock is rarely seen elsewhere except on the roadcuts, the fieldwork consisted mainly of study of the outcrops and float along the roads, shown on plate 1 , and along additional logging roads that branch off from these. In the northeastern part of the area, where ridges are barren and logging roads follow streams, the mapping consisted of rather widely spaced ridge and stream traverses, easily identified on plate 1 by the concentration of structure symbols. Geologic relations between traverses are largely interpretive, and plate 1 is therefore to be regarded as detailed reconnaissance.

\section{SPFCIMEN AND LOCALITY NUMBERS}

Specimen numbers are used as locality numbers and shown on the geologic map (pl. 1). The following gives township, range, and section for each locality.

\begin{tabular}{|c|c|c|c|}
\hline Number & Township & Range & Sec. \\
\hline 5 & T. $39 \mathrm{~N}$. & R. $4 \mathrm{E}$. & 18 \\
\hline 6 & T. $39 \mathrm{~N}$. & R. 3 E. & 24 \\
\hline (7- & T. $39 \mathrm{~N}$. & R. 2 E. & 24 \\
\hline 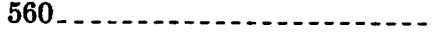 & T. $39 \mathrm{~N}$. & R. 2 E. & 24 \\
\hline 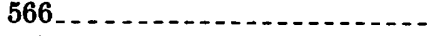 & T. $39 \mathrm{~N}$. & R. 3 E. & 9 \\
\hline 品 & T. $39 \mathrm{~N}$. & R. 2 E. & 12 \\
\hline 83 & T. $40 \mathrm{~N}$. & R. 2 E. & 9 \\
\hline 90 & T. $41 \mathrm{~N}$. & R. 2 E. & 33 \\
\hline 46 & T. $41 \mathrm{~N}$. & R. 2 E. & 20 \\
\hline 48 & T. $41 \mathrm{~N}$. & R. 2 E. & 20 \\
\hline - & T. $41 \mathrm{~N}$. & R. 2 E. & 29 \\
\hline - & T. $41 \mathrm{~N}$. & R. 1 E. & 25 \\
\hline - - & T. $41 \mathrm{~N}$. & R. 1 E. & 36 \\
\hline$-\ldots-1$ & T. $41 \mathrm{~N}$. & R. 1 E. & 35 \\
\hline $28 \ldots$ & T. $41 \mathrm{~N}$. & R. $2 \mathrm{E}$. & 24 \\
\hline 29 & T. $41 \mathrm{~N}$. & R. 2 E. & 12 \\
\hline - & T. $41 \mathrm{~N}$. & R. 2 E. & 10 \\
\hline 433 & T. $41 \mathrm{~N}$. & R. $2 \mathrm{E}$. & 8 \\
\hline 1435 & T. $41 \mathrm{~N}$. & R. 2 E. & 0 \\
\hline - & T. $41 \mathrm{~N}$. & R. 1 E. & 14 \\
\hline 1438 & T. $40 \mathrm{~N}$. & R. 1 E. & - \\
\hline 1441 & T. $40 \mathrm{~N}$. & R. 1 E. & 12 \\
\hline $1443 \ldots \ldots$ & T. $40 \mathrm{~N}$. & R. 3 E. & \\
\hline 1444 & T. $40 \mathrm{~N}$. & R. $3 \mathrm{E}$. & \\
\hline 445 & T. $41 \mathrm{~N}$. & R. $3 \mathrm{E}$. & 27 \\
\hline
\end{tabular}

\begin{tabular}{|c|c|c|c|}
\hline Number & Township & Range & Sec. \\
\hline $\begin{array}{l}1468 \\
1520\end{array}$ & $\begin{array}{l}\text { T. } 40 \mathrm{~N} \text { : } \\
\text { T. } 41 \mathrm{~N} \text {. }\end{array}$ & $\begin{array}{l}\text { R. } 3 \mathrm{E} . \\
\text { R. } 3 \mathrm{E} .\end{array}$ & $\begin{array}{r}14 \\
9\end{array}$ \\
\hline 1521 & T. $41 \mathrm{~N}$. & R. $3 \mathrm{E}$. & 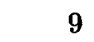 \\
\hline - & T. 42 N. & R. 3 E. & 32 \\
\hline 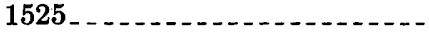 & T. $42 \mathrm{~N}$. & R. 2 E. & 14 \\
\hline-1 & T. $42 \mathrm{~N}$. & R. 2 E. & 14 \\
\hline $528 \ldots$ & T. $42 \mathrm{~N}$. & R. $2 \mathrm{E}$. & 14 \\
\hline 610 & T. $42 \mathrm{~N}$. & R. 2 E. & 11 \\
\hline 613 & T. $42 \mathrm{~N}$. & R. 2 E. & 11 \\
\hline 1615 & T. $42 \mathrm{~N}$. & R. $2 \mathrm{E}$. & 10 \\
\hline 1616 & T. $42 \mathrm{~N}$. & R. $2 \mathrm{E}$. & 10 \\
\hline - & T. $42 \mathrm{~N}$. & R. 2 E. & 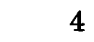 \\
\hline 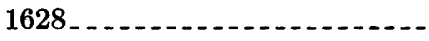 & T. 43 N. & R. 2 E. & 33 \\
\hline$-----1--1$ & T. $43 \mathrm{~N}$. & R. 2 E. & 23 \\
\hline - & T. $43 \mathrm{~N}$. & R. 3 E. & 27 \\
\hline 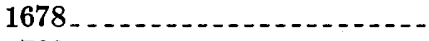 & T. $42 \mathrm{~N}$. & R. $3 \mathrm{E}$. & 5 \\
\hline 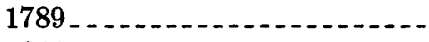 & T. $43 \mathrm{~N}$. & R. 2 E. & 14 \\
\hline - & T. $43 \mathrm{~N}$. & R. 2 E. & 18 \\
\hline 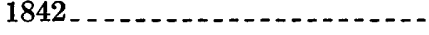 & T. $42 \mathrm{~N}$. & R. 1 E. & $\mathbf{3}$ \\
\hline 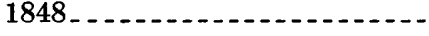 & T. $42 \mathrm{~N}$. & R. 1 E. & 15 \\
\hline 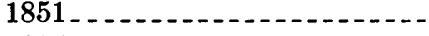 & T. $42 \mathrm{~N}$. & R. 1 E. & 29 \\
\hline - & T. $42 \mathrm{~N}$. & R. 1 E. & 3 \\
\hline - & T. $42 \mathrm{~N}$. & R. 1 E. & 3 \\
\hline - & T. $42 \mathrm{~N}$. & R. 1 E. & 3 \\
\hline 1904 & T. $42 \mathrm{~N}$. & R. 2 E. & 5 \\
\hline 1906 & T. $43 \mathrm{~N}$. & R. 2 E. & 33 \\
\hline 1908,1909 & T. $43 \mathrm{~N}$. & R. 2 E. & 23 \\
\hline - & T. $43 \mathrm{~N}$. & R. 2 E. & 13 \\
\hline - & T. $43 \mathrm{~N}$. & R. 2 E. & 14 \\
\hline - n- & T. $43 \mathrm{~N}$. & R. 2 E. & 14 \\
\hline$-\ldots-n-1-1-1-1$ & T. $43 \mathrm{~N}$. & R. 2 E. & 23 \\
\hline - n-n-n & T. $42 \mathrm{~N}$. & R. 2 E. & 11 \\
\hline 1919 & T. $41 \mathrm{~N}$. & R. 1 E. & 2 \\
\hline 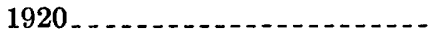 & T. $41 \mathrm{~N}$. & R. 1 E. & 1 \\
\hline 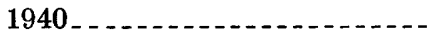 & T. $40 \mathrm{~N}$. & R. 2 E. & 31 \\
\hline$-1-2-1-1$ & T. $39 \mathrm{~N}$. & R. 3 E. & 14 \\
\hline$--1-1-1-1-$ & T. $40 \mathrm{~N}$. & R. 3 E. & 20 \\
\hline - n-n & T. $40 \mathrm{~N}$. & R. 3 E. & 14 \\
\hline$-\cdots-1-1-1$ & T. $40 \mathrm{~N}$. & R. 3 E. & 5 \\
\hline
\end{tabular}

1 North of pl. 1.

2 West of pl. 1.

\section{CLASSIFICATION OF THE ROCKS}

The rocks of the area arranged from oldest to youngest are grouped as follows:

1. Metasedimentary rocks of the Precambrian Belt series.

2. Plutonic outliers of the Idaho batholith, mainly quartz diorite, quartz monzonite, and granite of Cretaceous age.

3. Dikes and sills of gabbroic and granitic composition, of Tertiary (?) age.

4. Columbia River basalt of Miocene and Pliocene(?) age.

\section{BELT SERIES}

In the southern and eastern part of the Elk RiverClarkia area (pl. 1) the rocks equivalent to the Belt series are highly metamorphosed, but in the northwest the grade of metamorphism is somewhat lower, and in places sedimentary structures are preserved, 
such as crossbedding in the quartzitic layers of the Wallace formation. However, most of the sedimentary structures and colors that characterize the Belt series in the Coeur d'Alene district and elsewhere were obliterated during metamorphism, and the correlation must be based mainly on lithology. A sequence of thick beds of coarse-grained pure quartzite, equivalent to the Revett quartzite in lithology and stratigraphic position, was used as a key map unit. A layer of schist overlying this quartzite unit was mapped as St. Regis formation, and interbedded gneiss, quartzite, and schist above this schist were considered to be equivalent to the Wallace formation.

The Burke formation, which should underlie the Revett quartzite, could not be identified in the area. In the exposures found, the quartzite unit assigned to the Revett quartzite is separated by a fault from schist mapped as the Prichard formation. In some localities of poor exposures the quartzite unit seems to overlie schist conformably. Such a relation was found around Stony Butte and north of Breakfast Creek along the eastern edge of the area. In both localities, however, the underlying rock is a coarse-grained mica schist dissimilar to the Burke formation near Surveyors Ridge, where Umpleby and Jones (1923) mapped all the lowest five formations of the Belt series in a conformable sequence, and also dissimilar to the Burke formation in the Coeur d'Alene district (Ransome and Calkins, 1908). It seems, therefore, that either the Burke formation was not deposited here or the equivalent beds are included in the lowest part of the Revett quartzite or in the uppermost part of the Prichard formation.

\section{PRICHARD FORMATION}

\section{DISTRIBUTION AND LITHOLOGY}

Highly metamorphosed schist, gneiss, and quartzite exposed in the northeastern part of the area are continuous with the Prichard formation north of plate 1, as mapped by Pardee (1911) and by Umpleby and Jones (1923), who show the Prichard formation faulted against the Wallace formation to the west in the northeastern part of T. 43 N., R. 2 E. Several northward-trending faults and large faulted blocks of the Revett quartzite occur along the border of sections 12 and 13 of this township, just east of the southern end of the fault mapped by Umpleby and Jones. The fault zone that extends for about 5 miles southward from section 13 and then turns to a southeasterly direction separates the major area of schist of the Prichard formation from the overlying Revett quartzite and from the rocks equivalent to the St. Regis and the Wallace formations.
Small areas of coarse-grained mica schist that underlie conformably the Revett quartzite south of White Rock and north of Stony Butte and Breakfast Creek were mapped as the Prichard formation, because the schist is petrographically similar to the major part of the Prichard formation and no division could be made between it and the underlying beds. The major part of the rocks of the Prichard formation in the map area consists of coarse-grained garnetmica schist with minor amount of quartzite and biotiteplagioclase gneiss.

Numerous lenses of amphibolite and garnet amphibolite occur in the schist and gneiss. Some lenses may be sills or products of metasomatic processes, but at least some are metamorphosed lenses of calcareous shale deposited as part of the Prichard formation.

A discontinuous layer of micaceous quartzite, as much as $100 \mathrm{~m}$ thick, is interbedded with the schist on the southwest side of Glover Creek.

\section{STRATIGRAPHY}

The schist and gneiss of the Prichard formation in the Elk River-Clarkia area lie beneath a thick quartzite unit, which, north of this area, occurs in the upper part of the Prichard formation. This quartzite is well exposed on Lookout Mountain, 2 miles east of the area (Pardee, 1911). Therefore, most of the schist and gneiss under discussion probably are equivalent to beds that in northern Shoshone County form the lower part of the Prichard formation. The micaceous quartzite in the syncline southwest of Glover Creek may be stratigraphically equivalent to the quartzite on Lookout Mountain. Owing to structural complexities the thickness of the exposed Prichard could not be measured; it is probably several hundred meters.

Layers and sill-like bodies of coarse-grained gneiss and small masses of garnet amphibolite are irregularly scattered through the schist.

\section{PETROGRAPHY SCHIST}

Most of the schist of the Prichard formation is coarse to medium grained. Weathered surfaces are bronze colored; fresh surfaces, bluish gray. Numerous thin fine-grained quartzitic layers are interbedded with coarse-grained micaceous layers. The amount of the major constituents-quartz, plagioclase, biotite, muscovite, and garnet-vary markedly in the schist. Many plagioclase-rich layers contain hornblende.

The fine-grained layers are rich in quartz (60 to 80 percent) and contain some oligoclase; biotite is the main micaceous mineral. Red almandine garnet, 
tourmaline, magnetite, zircon, and rutile are minor constituents.

The coarse- to medium-grained layers contain 50 to 60 percent quartz and about 25 percent muscovite in large flakes; oligoclase is more abundant than in the fine-grained layers, constituting 1 to 20 percent of the rock. Garnet crystals range from 2 to $20 \mathrm{~mm}$ in diameter and constitute about 10 percent of the rock. They are subhedral to round or oval and include numerous small round quartz grains. Biotite is either interleaved with muscovite or in separate thin laminae made of flakes 1 to $2 \mathrm{~mm}$ in diameter. Magnetite, zircon, tourmaline, and corundum are accessories. The amount of biotite increases and that of muscovite decreases toward the south.

The coarse-grained garnet-mica schist around Stony Butte consists of quartz ( 30 to 50 percent), plagioclase (2 to 20 percent), muscovite (10 to 20 percent), biotite (about 10 percent), and garnet. In addition to these major constituents many layers contain 1 to 2 percent of kyanite and tiny subhedral crystals of staurolite. Apatite, tourmaline, and zircon occur as accessories. Shiny prisms of black tourmaline, $1 \mathrm{~cm}$ long and $4 \mathrm{~mm}$ thick, were found in some strongly sheared layers about a mile east of Stony Butte. This tourmaline is dravite with $\omega=1.638 \pm 0.002$.

In many places, fine-grained quartzitic layers, 1 to $10 \mathrm{~cm}$ thick, are interbedded with the schist. In some of these layers (for example, loc. 1677, southeast of Grandmother Mountain) are lenses as much as $2 \mathrm{~m}$ long which contain zoisite, indicating that the strata were slightly calcareous.

\section{GNEISS}

The schist unit contains many medium- to coarsegrained gneissic layers and lenses that grade locally to coarse-grained gneissic quartz diorite or to gneissic tonalite and gray granite. The gneisses have abundant oligoclase, very little if any muscovite, and much less quartz than the average schist. Veins and silllike bodies of pegmatite are common. The major constituents of pegmatite are plagioclase and quartz; biotite, garnet and (or) hornblende are minor.

Near several small bodies of granite and quartz diorite north of Glover Creek and south of Grandmother Mountain gneiss makes up about 40 percent of the Prichard formation. Elsewhere the amount of this rock type is much less (about 15 percent).

Plagioclase $\left(\mathrm{An}_{25-30}\right)$ constitutes about 60 percent of the gneiss, quartz about 20 percent, and biotite 10 to 15 percent. The remaining 5 to 10 percent is hornblende, garnet, and epidote in varied amounts. The accessories are apatite, magnetite, zircon, and locally tourmaline. There is every gradation from these gneissic 690-237 $0-63-2$ layers to a schist in which the amount of quartz is about 60 percent and in which plagioclase is scarce or lacking.

A very coarse grained gneiss, rich in plagioclase and containing large crystals of garnet and of blue kyanite, crops out just west of Freezeout Mountain. The garnets range from $1 / 2$ to $3 \mathrm{~cm}$ in diameter; many are enveloped by biotite. This garnet-kyanite gneiss is similar to the plagioclase-rich country rock of the anorthosite in the Boehls Butte quadrangle (Hietanen, 1963).

About a mile west of Freezeout Mountain anthophyllite prisms, 2 to $6 \mathrm{~mm}$ long, occur in plagioclaserich layers, about $20 \mathrm{~cm}$ thick, in the schist. The indices of refraction of the anthophyllite are $a=1.659 \pm$ $0.001, \beta=1.670 \pm 0.002, \gamma=1.681 \pm 0.001 ; 2 \mathrm{~V}$. is large. These optical properties are close to those of the aluminous anthophyllite described by Rabbitt (1948) from the Cherry Creek area, Montana.

\section{QUARTZITE}

The quartzite interbedded with the schist of the Prichard formation on the southwest side of Glover Creek is a light-gray medium-grained rock in which shiny muscovite flakes, $1 / 4$ to $2 \mathrm{~mm}$ in diameter, are evenly scattered throughout most beds.

Most of the quartz grains are flattened in the plane of foliation. In this plane they are 0.2 to $0.3 \mathrm{~mm}$ in diameter and almost equidimensional. The orientation of the muscovite flakes suggests a weak northeastward-striking lineation; and about 80 percent of the quartz grains have their $c$-axes parallel to the same direction.

\section{GARNET AMPHIBOLITE}

Several elongate bodies of dark well-foliated amphibolite and garnet amphibolite occur in the schist of the Prichard formation. Some of them are probably sedimentary in origin. Many, however, are metamorphosed sills and dikes and some are metasomatic. Because all varieties are petrologically alike and the origin of individual bodies is uncertain, all the amphibolite and garnet amphibolite are described in the section on plutonic rocks.

\section{REVETT QUARTZITE}

\section{DISTRIBUTION AND LTTHOLOGY}

A sequence of thick beds of coarse-grained nearly pure quartzite is assigned to the Revett quartzite. Easy to identify in the field, the unit was used as a key in mapping. In most places the lower beds of the Revett quartzite are faulted against the Prichard formation or the Wallace formation. Where conformable contacts are indicated, biotite schist, possibly 
equivalent to the Burke formation but inseparable from the schist of the Prichard formation, underlies the Revett quartzite.

The Revett quartzite crops out in and near the fault zone that passes through the area from the northern border to the south and southeast. Widest distribution is along Breakfast Creek in T. 40 N., R. 3 E., and T. 41 N., R. 3 E.

\section{STRATIGRAPHIC SEQUENCE AND THICKNESS}

The stratigraphic sequence is interrupted by numerous faults, many of which occur along the contact of the massive Revett quartzite or cut across its beds. Because of this faulting and the lack of outcrops, the complete section is not exposed and the thickness could not be measured.

Nearly complete sections of the Revett quartzite are exposed along Breakfast Creek and to the south. There the lowest beds are light bluish gray; they are overlain by thick beds of white quartzite, which grades to pink or light brownish red quartzite toward the top. The thickness of this section is estimated to be about $500 \mathrm{~m}$, which is close to the thickness of the Revett quartzite in southern Shoshone County (Umpleby and Jones, 1923).

\section{PETROGRAPHIC DESCRIPTION}

The Revett quartzite is coarse grained and has splintery fracture. Individual grains in the splinters have shiny surfaces that resemble cleavage planes but are not as smooth. These shiny surfaces are typical only of quartzites of the Revett and are probably due to the deformation and orientation of quartz. They are not found in vein quartz, the blocks of which otherwise resemble the coarse-grained Revett quartzite. The quartzites of the Prichard and Wallace formations also are easily distinguished from the Revett quartzite because their quartz grains are small, rounded, and dull.

Beds of nearly pure quartzite, $5 \mathrm{~cm}$ to $1 \mathrm{~m}$ thick, are separated by paper-thin muscovite laminae. In a few places one or two layers of schist, 2 to $10 \mathrm{~m}$ thick, are interbedded with the coarse-grained quartzite. The beds of quartzite consist of 95 to 99 percent quartz and a few scattered grains of plagioclase, biotite, and muscovite. The plagioclase, biotite, and muscovite occur between irregularly shaped strained grains of quartz, as do a few grains of rutile, zircon, and magnetite. Some large grains of quartz show shadowy mosaic texture, which suggests that many tiny grains were compined to form each large grain. Parallel orientation of the $c$-axes and strong strain shadows indicate that recrystallization occurred during deformation.

\section{ST. REGIS FORMATION}

\section{DISTRIBUTION AND IITHOLOGY}

A layer of schist that separates the Revett quartzite from the overlying diopside- and hornblende-bearing gneiss and quartzite of the Wallace formation is assigned to the St. Regis formation. This division is applicable in the central part of the area, but locally in the southeastern part the schist equivalent to the St. Regis formation could not be identified with certainty, because the lowest gneiss-quartzite unit of the overlying Wallace formation thins out southeast of Elk Butte and appears higher in the series south of Elk Butte. The schist equivalent to the Wallace formation may therefore overlie the St. Regis formation in this southern part. Because these schists are petrographically alike and thus indistinguishable, a part of the schist north of Gold Butte mapped as the Wallace formation may be equivalent to the St. Regis formation. The estimated thickness of the schist of the St. Regis formation along Breakfast Creek is about $150 \mathrm{~m}$, which is only about one-half the thickness exposed in Shoshone County (Umpleby and Jones, 1923).

\section{PETROGRAPHY}

The St. Regis formation is muscovite-biotite schist that contains up to 15 percent garnet. Specimens from the lower beds along Breakfast Creek are strongly sheared, with micas in thin shreds parallel to the foliation. Muscovite flakes are bent and show strain shadows under crossed nicols. Most of them are larger than the interleaved biotite flakes. Some of the largest biotite flakes are also strained but not as strongly as the muscovite.

The measured mode of typical schist from the lower part of the St. Regis formation is 60 percent quartz, 20 percent muscovite, 15 percent biotite, 4 percent plagioclase, and about 1 percent garnet, apatite, magnetite, and zircon. The upper part of the formation has more garnet and less quartz. In many localities mediumgrained layers containing less muscovite and more biotite are interbedded with muscovite-rich schist. Many beds have large muscovite flakes in thick plates oriented at an angle of about $2^{\circ}$ to $10^{\circ}$ from the plane of foliation.

Beds of similar schist occur in the Prichard formation and in the Wallace formation; therefore, only the stratigraphic position of the schist immediately above the massive Revett quartzite and beneath the quartzite-gneiss unit of the Wallace formation indicates that the schist is equivalent to the St. Regis formation. 
WALLACE FORMATION

\section{DISTRIBUTION AND LITHOLOGY}

The Wallace formation is the most widespread and varied formation in the area; schist, gneiss, and quartzite assigned to it underlie the western and southern two-thirds.

In the northern part of the area the Wallace has been subdivided into four map units:

Upper schist unit

Upper quartzite-gneiss unit

Lower schist unit

Lower quartzite-gneiss unit

Some thin but mappable gneiss layers are also interbedded in the lower schist unit. Comparison of this subdivision with that of Shenon and McConnel (1939, p. 5) in the Coeur d'Alene district suggests that the lower and upper schist units near Elk River and Clarkia are the metamorphosed equivalents of the thinly laminated, noncalcareous argillite of the Coeur d'Alene district (subdivisions 2 and 4 of Shenon and McConnel). Sequences corresponding to the limy quartzite and sandy, shaly, and arenaceous limestones near Coeur d'Alene were recrystallized as quartzites and as biotite, biotite-plagioclase, and diopside or hornblende gneisses near Elk River and Clarkia. These petrographically different rock types were not mapped separately, however, because of their irregular distribution and discontinuous exposure.

In the southeastern part of the area the Wallace formation has been subdivided into five units. The upper four units seem to be the same as those in the northern part though the quartzite-gneiss units are somewhat thinner and a third unit of schist underlies the lower quartzite-gneiss unit. This subdivision corresponds to that of Wagner $(1949$, p. 9), who distinguished two units of noncalcareous black shale, two units of calcareous shaly sandstone, each 500 to 800 feet thick, and a basal unit, 2,000 feet thick, consisting of impure quartzite, shale, and sandstone with. occasional limestone layer, in the Wallace formation near St. Joe River, about 13 miles north of the present area.

A transition from the northern to the southern subdivision takes place near Elk Butte, where the lower quartzite-gneiss unit thins out southward and another quartzite-gneiss unit appears within the schist of the Wallace formation, apparently about $600 \mathrm{~m}$ above the base, so that the sequence consists of two quartzitegneiss units and three schist units. Since the schist of the St. Regis formation is petrologically similar to the basal schist of the Wallace formation, no contact could be mapped between these two formations south of Elk Butte; thus all schist between the Revett quartzite and lower quartzite-gneiss unit of the Wallace formation was mapped as a part of the Wallace formation.

All the schist units are petrographically much alike. The major part of the schist contains either kyanite and staurolite or sillimanite in addition to quartz, biotite, muscovite, and garnet. The schist is coarsegrained in the central and southern part of the area, but fine to medium grained in the northwestern part. Some layers of thin-bedded biotite quartzite with muscovite and biotite laminae are interbedded with the schist.

The two quartzite-gneiss units are mainly of bedded diopside-plagioclase gneiss and quartzite with minor schist layers. Most of the quartzite is thin bedded and contains much biotite and (or) diopside. Thick layers of white granular quartzite with a little feldspar or diopside are interbedded with the diopside-plagioclase gneiss in the lower part of the formation.

The lower quartzite-gneiss unit is exposed within and just west of the fault zone that crosses the area from the northern border to the south and southeast. The upper quartzite-gneiss unit covers the westernmost part of the area. Thin-bedded biotite quartzite and diopside quartzite between the stocks of quartz monzonite and quartz diorite probably belong to the upper unit.

\section{STRATIGRAPHY AND CORRELATION}

No complete section of the Wallace formation is available; however, several good partial sections are exposed along logging roads.

The lower quartzite-gneiss unit is best exposed east and northeast of Clarkia along the St. Maries River and its tributaries. The lowermost beds consist of white granular quartzite, which are interbedded with some thin layers of biotite quartzite, hornblende-bearing quartzite, and hornblende gneiss. These beds ( $1 a$, table 1) cover a wide area along the forks of Merry Creek cropping out along the crest of a gentle anticline. Similar quartzite, but with diopside rather than hornblende, overlies the Revett quartzite and the schist of the St. Regis formation north of Isabella Creek.

Along the St. Maries River, the white granular quartzite is overlain by thin-bedded white and gray banded biotite quartzite with some schist layers $(1 b$, table 2). Together these two subunits ( $1 a$ and $1 b$ ) correspond in their thickness and stratigraphic position to the lowest member of the Wallace formation in Wagner's (1949) subdivision of this formation near the St. Joe River.

A green and white banded diopside-plagioclase gneiss with abundant tremolite, exposed on the north side of the St. Maries River at the mouth of Gold Center Creek, lies stratigraphically above the thin-bedded 
TABLE 1.-Generalized section of the lower quartzite-gneiss unit of the Wallace formation, exposed along Merry Creek in secs. 23 and $14, T .43$ N., R. $2 E$.

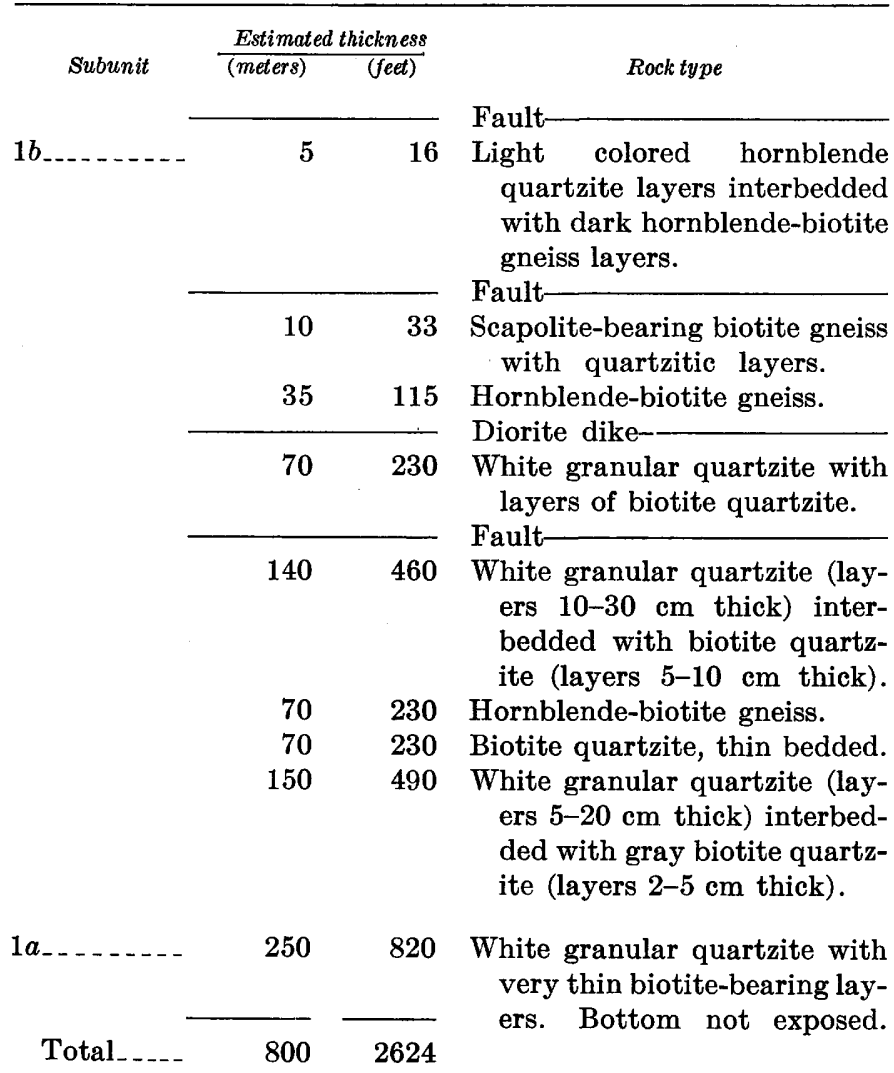

biotite quartzite. This diopside-tremolite-plagioclase gneiss $(1 c)$ corresponds to member 2 in Wagner's subdivision.

In the extreme southeastern corner the lowest quartzite gneiss unit resembles the lower quartzite gneiss exposed along Merry Creek; in both sections the white granular quartzite is the major rock type. Two good sections of this quartzite, each about $250 \mathrm{~m}$ thick, are well exposed on the flanks of an anticline along the North Fork of the Clearwater River. In these sections individual beds of white granular quartzite range from 10 to $40 \mathrm{~cm}$ in thickness and are separated by beds of biotite gneiss 3 to $4 \mathrm{~cm}$ thick. The unit is underlain by thin-bedded biotite gneiss and biotite schist with quartzitic layers and is overlain by coarse-grained sillimanite garnet schist. The western flank of this anticline is exposed along the ridge between Falls Creek and Weitas Creek, where most beds contain much plagioclase and diopside, some beds contain amphiboles, and a few beds, potassium feldspar. The gneiss units exposed south of Green Mountain and east of Gold Butte consist mainly of diopsideplagioclase gneiss with some actinolite or hornblende resembling the corresponding rock types in the Boehls Butte quadrangle (Hietanen, 1963) and in the Head-
TABLE 2.-Generalized section of the lower quartzite-gneiss unit of the Wallace formation along the St. Maries River, secs. 11, 14, and $23, T .42 N$., R. $2 \mathrm{E}$.

\begin{tabular}{|c|c|c|c|}
\hline \multirow[b]{2}{*}{ Subunit } & \multicolumn{2}{|c|}{ Estimated thickness } & \multirow[b]{2}{*}{ Rock type } \\
\hline & (meters) & $\overline{(\text { feet })}$ & \\
\hline $1 c_{\ldots} \ldots$ & 200 & 655 & $\begin{array}{l}\text { Diopside-plagioclase gneiss } \\
\text { with tremolite or actinolite. }\end{array}$ \\
\hline \multirow[t]{8}{*}{$1 b_{\ldots} \ldots \ldots$} & 30 & 100 & $\begin{array}{l}\text { Thin-bedded (1/2-2 cm thick } \\
\text { beds) biotite quartzite with } \\
\text { diopside-hornblende-plagio- } \\
\text { clase quartzite layers. }\end{array}$ \\
\hline & 30 & 100 & $\begin{array}{l}\text { Banded dense dark quartzite } \\
\text { with biotite or diopside and } \\
\text { hornblende in alternating } \\
\text { layers that are } 2-10 \mathrm{~mm} \\
\text { thick. }\end{array}$ \\
\hline & 70 & 230 & $\begin{array}{l}\text { Thin-bedded biotite quartzite } \\
\text { with layers, } 5-10 \mathrm{~mm} \text { thick, } \\
\text { consisting of pure quartzite. }\end{array}$ \\
\hline & 150 & 490 & $\begin{array}{l}\text { Biotite-plagioclase schist, me- } \\
\text { dium grained. }\end{array}$ \\
\hline & 30 & 100 & $\begin{array}{l}\text { Biotite-plagioclase quartzite in- } \\
\text { terbedded with biotite quart- } \\
\text { zite and containing some } \\
\text { schist layers; variation in } \\
\text { the composition between } \\
\text { the layers is only slight. }\end{array}$ \\
\hline & 70 & 230 & $\begin{array}{l}\text { Thin-bedded gray and white } \\
\text { granular quartzite with } \\
\text { quartz veins, } 2-5 \mathrm{~mm} \text { thick. }\end{array}$ \\
\hline & 20 & 65 & $\begin{array}{l}\text { Biotite-rich banded quartzite; } \\
\text { light colored layers are few } \\
\text { and thin, muscovite-biotite } \\
\text { schist is interbedded. }\end{array}$ \\
\hline & 10 & 35 & $\begin{array}{l}\text { Thin-bedded biotite quartzite } \\
\text { with hornblende in some } \\
\text { dark layers. }\end{array}$ \\
\hline
\end{tabular}

$1 a$ ite.

$10 \quad 35 \quad$ Biotite schist.

$30 \quad 100$ White quartzite with muscovite laminae, beds $5-15 \mathrm{~cm}$ thick.

30100 Thin-bedded granular pure quartzite with biotite-bearing layers.

160525 Granular coarse- to mediumgrained pure quartzite.

2065 Very thin bedded quartzite, white pure quartzite layers and biotite quartzite layers alternating.

Total_... $\quad \overline { 8 7 0 } \longdiv { 2 8 6 5 }$

quarters quadrangle (Hietanen, 1962). Diopside quartzite and diopside-plagioclase gneiss exposed in the south-central part of the area underlie schist of the Wallace formation and most likely belong to the lower quartzite-gneiss unit. A small lenslike body of diopside gneiss interbedded with the schist southeast of Little Green Mountain is lithologically similar to the 
southwesterly dipping lower unit exposed just northeast of it and may be a part of this unit brought up along the crest of an anticline. However, a similar small body of diopside gneiss is interbedded with the schist about 2 miles to the north in the vicinity of Camp 43, and a third such body is about half a mile south of Green Mountain. It seems, therefore, that in the area south of Elk Butte two thinner quartzose sequences, which recrystallized to quartzite and gneiss, instead of one thick sequence were deposited in the lowest part of the Wallace formation. The geologic maps of the Headquarters quadrangle and of the area adjoining this quadrangle in the west also show several thin units rather than two thick units of diopside and biotite gneiss in the schist of the Wallace formation (Hietanen, 1962).

The lower quartzite-gneiss unit is overlain by garnetiferous mica schist, most of which contains either kyanite or staurolite or sillimanite. A good section through the lower schist unit is exposed along the St. Maries River east of Clarkia. The major part consists of fine- to medium-grained muscovite-biotitegarnet schist with some thin-bedded gray quartzitic layers. Most of the schist cleaves parallel to the bedding, but rocks in some outcrops have a fairly well developed transecting cleavage; all cleavage planes have light to medium- gray silvery surfaces peppered with small dark red garnets. Most of the schist is thinly laminated; micaceous layers, 1 to $10 \mathrm{~mm}$ thick, alternate with quartz-rich layers, which are 5 to $10 \mathrm{~mm}$. Layers of homogeneous schist, 10 to $50 \mathrm{~cm}$ thick, and other layers consisting of biotite quartzite with muscovite laminae are interbedded with the laminated schist. Many outcrops of schist in the southern part of the area are crudely laminated with quartz-rich layers, 3 to $5 \mathrm{~mm}$ thick, separated by paper-thin mica laminae.

Folding and faulting makes estimation of the thickness of this schist unit difficult. A thickness of about $1,100 \mathrm{~m}$ is estimated near Elk Butte, where the lower quartzite-gneiss unit is only about $100 \mathrm{~m}$ thick. Together these would well correspond to the combined thickness of the three lowest members in Wagner's subdivision $(3,450 \mathrm{ft})$. The thickness of the lower schist unit near Anthony Peak is at least $350 \mathrm{~m}$ (more than $1,000 \mathrm{ft}$ ), and thus a little thicker than that of the corresponding unit near the St. Joe River $(850 \mathrm{ft}$ according to Wagner).

The garnetiferous kyanite- and sillimanite-bearing mica schist is overlain by a second quartzite-gneiss unit consisting of interbedded quartzite, diopside- and amphibole-bearing gneiss, and fine-grained mica schist. This upper quartzite-gneiss unit is well exposed along the East Fork of Potlatch Creek and its tributaries, and on the lower slopes of Jackson Mountain. Folding and faulting have obscured the stratigraphic sequence. The lower schist unit and the upper quartzite-gneiss unit are in conformable contact near the forks of Mallory Creek and along the East Fork of Mallory Creek. The schist along the East Fork and the West Fork of Mallory Creek is coarse grained, rich in muscovite and biotite, and contains abundant pegmatitic veins and a few layers, about $1 \mathrm{~m}$ thick, of micaceous quartzite. Above this schist along Mallory Creek is a sequence of fine- to medium-grained distinctly bedded quartzites with layers rich in diopside and feldspars (table 3).

TABLE 3.-Generalized section of the upper quartzite-gneiss unit of the Wallace formation along Mallory Creek and the East Fork of Potlatch Creek, west of the mouth of Mallory Creek.

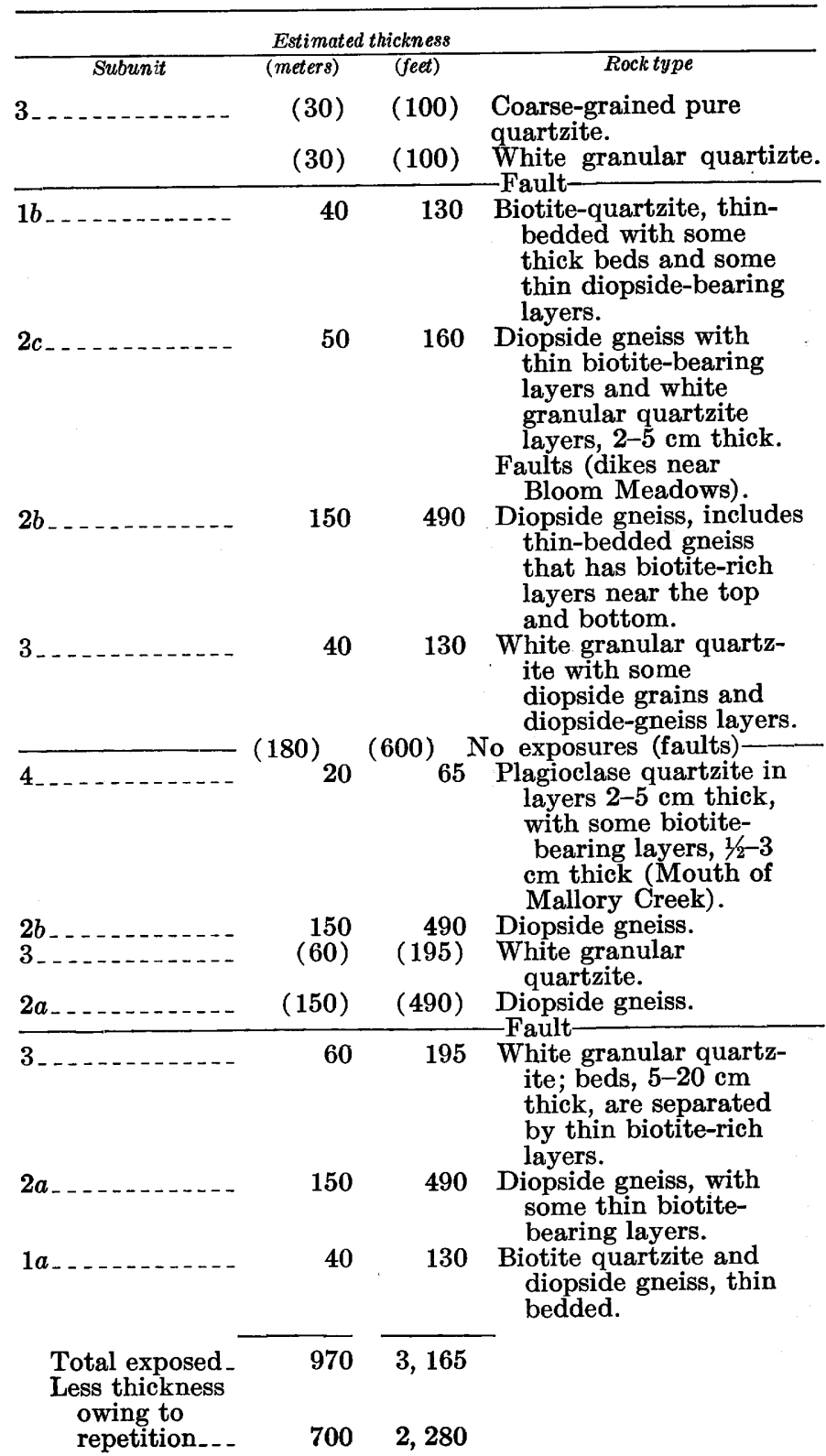




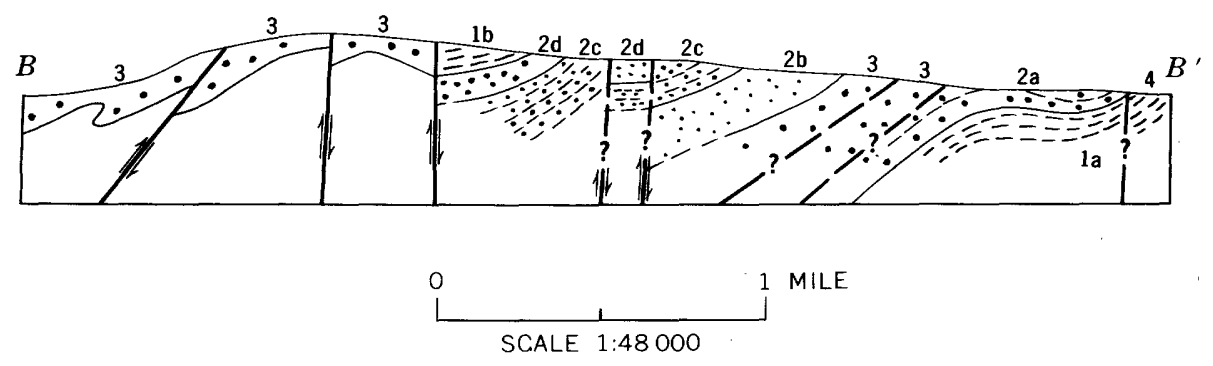

\begin{abstract}
Figdre 2.-A cross section through the upper quartzite-gneiss unit of the Wallace formation near Bloom Meadlows ( $B-B^{\prime}$ on pl. 1). $1 a$ and $1 b$ are thin-bedded biotite quartzite with thin layers of diopside gneiss. $2 a, 2 b, 2 c$ and $2 d$ are mainly diopside gneiss with thin biotitebearing layers; $2 a$ and $2 c$ have more of these biotite-bearing layers than $2 b$ and $2 d$. Layers of white granular quartzite are interbedided in $2 c$. Subunit 3 consists of fairly pure granular quartzite that is coarse grained in the western part of the section.
\end{abstract}

The sequence has been divided into four lithologic subunits numbered on table 3. Structural repetition is shown by repetition of numbers. Depositional repetition of similar rock types is indicated by letters. The section is complicated by faulting similar to that in figure 2, which shows a cross section along line $B-B^{\prime}$ on plate 1 . The stratigraphic column is further complicated by lateral changes in the amounts of the major constituents, quartz, diopside, plagioclase, and biotite. The white granular beds (No. 3) may laterally grade into biotite-, diopside-, or plagioclase-bearing layers (Nos. $2 a, 2 b, 2 c$, or 4). Diopside gneiss grades laterally into thin-bedded biotite-bearing gneiss, making the distinction between the subunits 1 and 2 doubtful. The plagioclase quartzite (No. 4) may contain also diopside-rich layers, and parts of it are similar to the thin-bedded diopside-biotite gneiss of subunit No. 1. The individual layers in all the subunits range from a few millimeters to $20 \mathrm{~cm}$ or more. In the thinbedded diopside-biotite gneiss the thicknesses of 1 to 5 $\mathrm{cm}$ are most common (fig. 3 ). In the majority of outcrops the biotite-rich layers are thinner than the plagioclase- and diopside-bearing layers; locally the micaceous laminae are paper thin between quartzitic or gneissic layers that contain very little or no mica. In some parts of the sequence, beds 1 to $5 \mathrm{~m}$ thick consist of thin layers, 1 to $2 \mathrm{~cm}$ thick, of biotite quartzite separated by mica-rich laminae. These biotite quartzite or biotite gneiss beds alternate either with plagioclase quartzite or with diopside-plagioclase gneiss beds of the same thickness. In some other parts of the unit, biotite schist instead of biotite quartzite and gneiss is interbedded with diopside-plagioclase gneiss. Thick beds of coarse-grained pure quartzite resembling the Revett quartzite are exposed next to the white granular quartzite in sec. 2, T. $40 \mathrm{~N}$., R. 1 E. and in secs. 23 and 34, T. 41 N., R. 1 E. This coarse-grained quartzite may represent an upper part of the subunit 3 (top of table 3 ) in this vicinity and establish a structural repetition just east of the mouth of Bobs Creek and about a mile south of Bloom Meadows (cross section $B-B^{\prime}$, pl. 1 ).

The thickness of the subunits in individual sections can be estimated, but detailed mapping of the subunits would be necessary to establish a complete stratigraphic column. However, this would be a difficult and time-consuming task, because the structure is complicated by many faults and by several sets of folds (Hietanen, 1961a), and because similar layers occur in several subunits. In addition, there is considerable lateral variation on a large scale, which makes the correlation of subunits of different parts of the area difficult if not impossible. For instance, most of the section of the upper quartzite-gneiss unit along Emerald Creek, west of Clarkia, consists of white granular quartzite. Only the uppermost $200 \mathrm{~m}$ of this section, which is about $1,300 \mathrm{~m}$ thick, consists of thin-bedded biotite quartzite. Some diopside-bearing layers are interbedded in the upper part of the white granular quartzite. The sequence exposed west of Cedar Butte near Clarkia contains more diopside gneiss and less white granular quartzite. Most of the same unit south of Shattuck Butte consists mainly of diopside gneiss and thin beds of biotite gneiss and biotite quartzite; the thickness of the white granular quartzite there is less than along the East Fork of Potlatch Creek and much less than on Emerald Creek, and many beds contain diopside. Near Elk River there is more diopside gneiss and much less white granular quartzite than along the East Fork of Potlatch Creek, but the quartzite is purer. Thus the thickness and sequence of the subunits in each individual section varies considerably. The average total thickness of the unit is probably about $1,000 \mathrm{~m}$.

\section{PETROGRAPHY}

The two schist units of the Wallace formation are petrographically alike and are therefore discussed under one heading. The quartzite-gneiss units comprise four main intergradational rock types: (1) thin- 

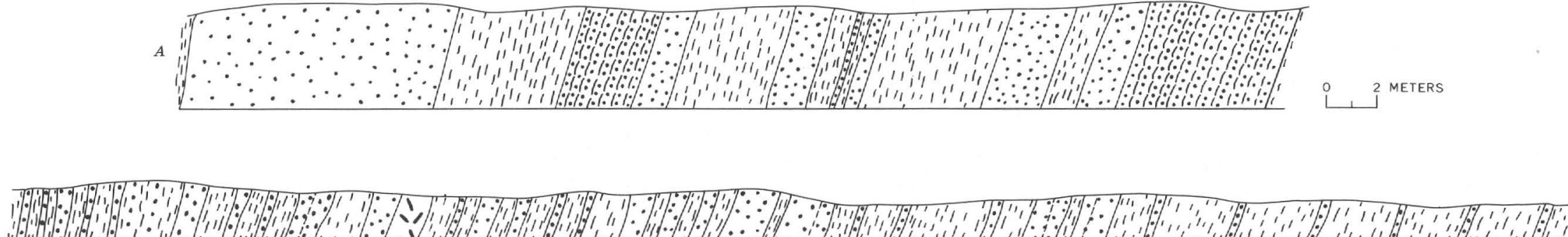
$\begin{array}{lll}B & 1\end{array}$

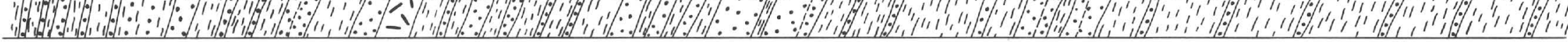
EXPLANATION

\begin{tabular}{|c|c|c|c|}
\hline $\begin{array}{l}\text { Thin-bedded biotite } \\
\text { and diopside gneiss }\end{array}$ & Diopside gneiss & Pegmatite & $\begin{array}{l}\text { Biotite schist } \\
\text { and gneiss }\end{array}$ \\
\hline i & & & MET \\
\hline
\end{tabular}

Frgure 3.-Bedding in biotite and diopside gneiss along the head of Shattuck Creek, 2 miles east of Jackson Mountain. A, Beds of diopside gneiss, $0.2-10$ meters thick, inter bedded with biotite schist and thin-bedded gneiss; $B$, Detail of thin-bedded gneiss. 
bedded biotite and diopside gneiss and quartzite, (2) diopside or hornblende gneiss, (3) white granular quartzite, and (4) thin-bedded biotite-plagioclase quartzite and gneiss.

\section{SCHIST}

In the northwestern part of the area the schist is fine- to medium-grained thinly laminated muscovitebiotite-garnet schist (fig. $4 A$ ) with local development of kyanite (fig. $4 B$ ) and staurolite.

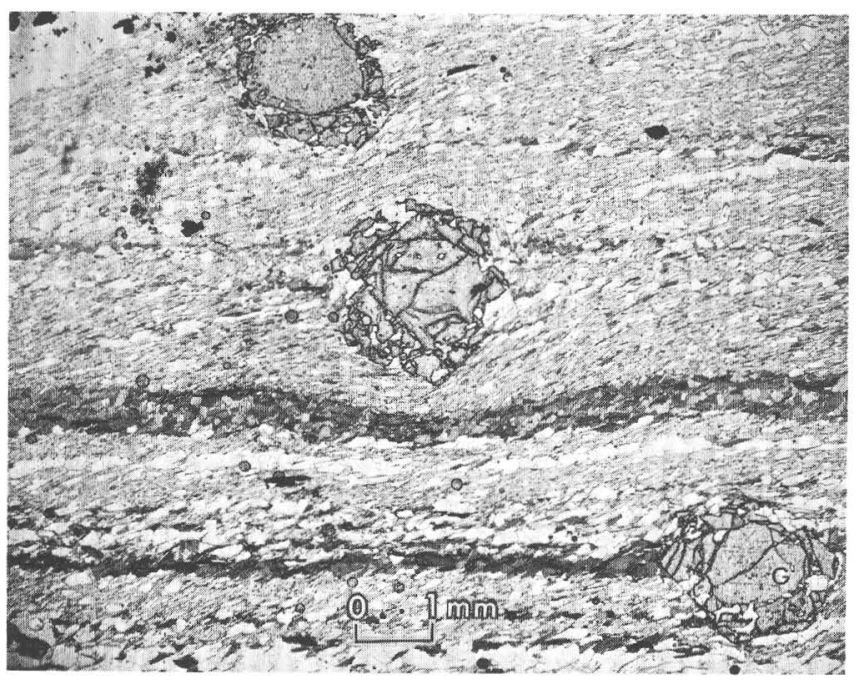

A. Laminated fine-grained garnet-mica schist from Bechtel Mountain (loc. 1848), 3 miles west-southwest of Clarkia. Dark bands are biotite laminae in the muscovite schist. Note that the euhedral cores in garnets (G) contain only a few tiny inclusions of quartz (white) whereas the rims contain abundant quartz. The orientation of muscovite flakes (light gray) shows the direction of cleavage. Plane polarized light.

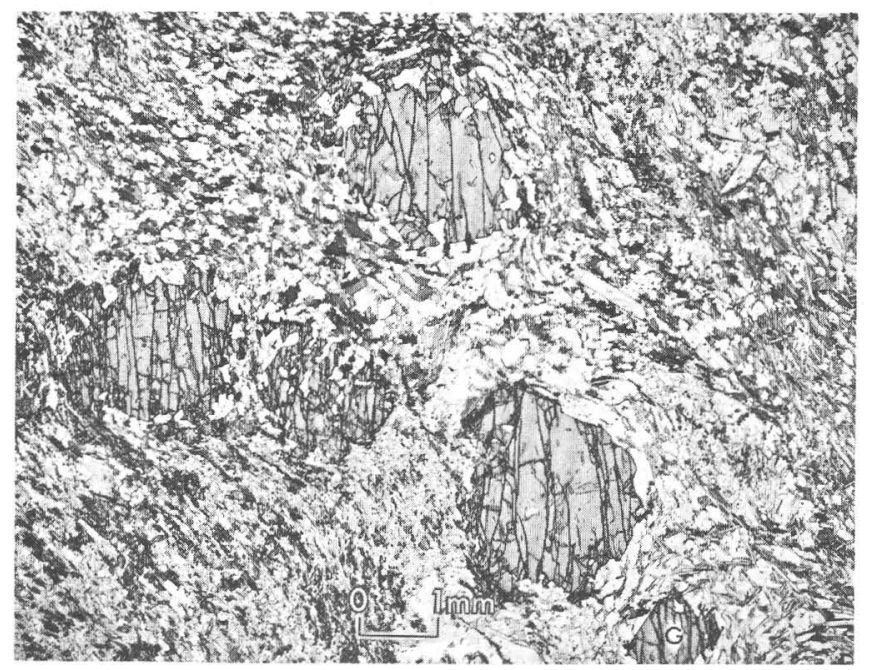

$B$. Garnet-kyanite schist, 1 mile west of Gold Center (loc. 1615). Small kyanite $(K)$ crystals occurs in aggregate and nodules in this mediumgrained rock. Dark mineral is biotite, light-colored minerals are muscovite and quartz; G-garnet. Plane-polarized light.

Figure 4.-PHOTOMICROGRAPHS OF SCHIST OF THE WALLACE FORMATION IN THE NORTHERN PART OF THE AREA.
Toward the south and southeast the grain size becomes larger, the thin lamination is locally obscured by more intense recrystallization, and sillimanite instead of kyanite is a prevalent aluminum silicate (fig. 5A). Interbedded with the schist are fine-grained quartzrich layers, many of which contain muscovite laminae (fig. $5 B$ ).

The thicker layers in the schist consist of quartzmuscovite-biotite rock with numerous subhedral gar-

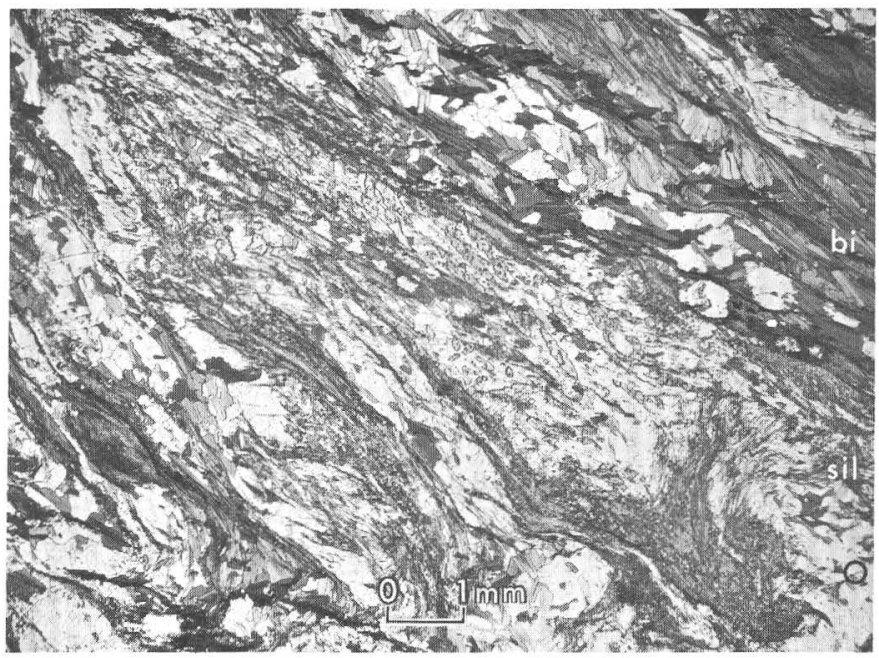

A. Sillimanite-mica schist from Hemlock Butte in the central part of the area (loc. 1429). Biotite (bi) occurs more abundantly in certain thin layers which correspond to the laminae of figure $4 A$ but are partly obscured by a strong deformation and recrystallization. Sillimanite (sil), quartz (Q). Plane-polarized light.

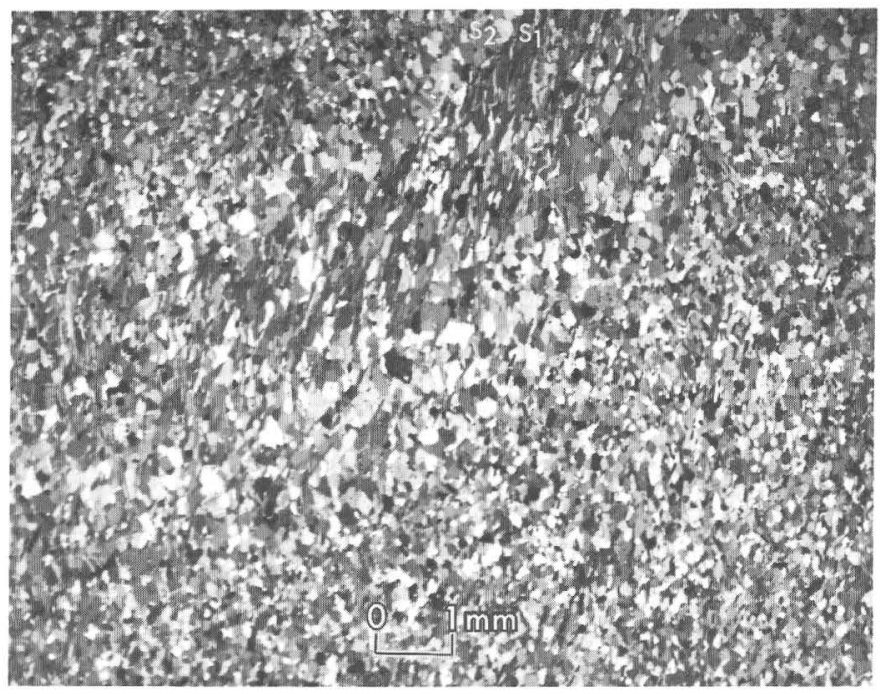

$B$. A quartzitic layer in garnet-mica schist about 1 mile west of Gold Center. The orientation of mica flakes $\left(\mathrm{s}_{2}\right.$ almost vertical) shows the plane of foliation which makes an angle from $50^{\circ}$ to $80^{\circ}$ with the bedding plane $s_{1}$ that crosses the photograph diagonally from lower left to the upper right corner. Crossed nicols.

FIGURE 5.-PHOTOMICROGRAPHS OF A SILLIMANITE SCHIST AND A QUARTZITE LAYER IN SCHIST OF THE WALLACE FORMATION. 
nets and white nodules consisting of muscovite, kyanite, and a few tiny crystals of staurolite. Apatite, magnetite, tourmaline, sphene, and zircon occur as accessories.

The mode of a typical layer in the schist from about a mile west of Gold center is: 28 percent quartz, 31 percent muscovite, 19 percent biotite, 12 percent kyanite, 9 percent garnet, 1 percent staurolite and accessories. The quartz is in irregular grains 0.1 to 0.3 $\mathrm{mm}$ in diameter. Interleaved biotite and muscovite flakes, 0.2 to $1 \mathrm{~mm}$ in diameter, occur between the quartz grains. Clusters of larger flakes of muscovite are scattered through the schist or are next to nodules, 1 to $2 \mathrm{~cm}$ in diameter, of muscovite and small grains of kyanite (fig. 6). In some layers these nodules have nearly square cross sections, suggesting that they are pseudomorphs after andalusite.

Garnet crystals in the schist are subhedral, $1 / 2$ to 2 $\mathrm{mm}$ in diameter, and contain many round quartz inclusions. The index of refraction $n=1,805 \pm 0.003$ and the unit cell dimension $\mathrm{a}_{0}=11.582 \pm 0.006 \mathrm{~A}$ were measured in a garnet from the schist along Marble Creek. According to the diagrams by Sriramadas (1957) these values indicate that the garnet is almandite with about 18 percent grossularite and 8 percent pyrope. Staurolite crystals, 3 to $7 \mathrm{~mm}$ long, occur in some layers.

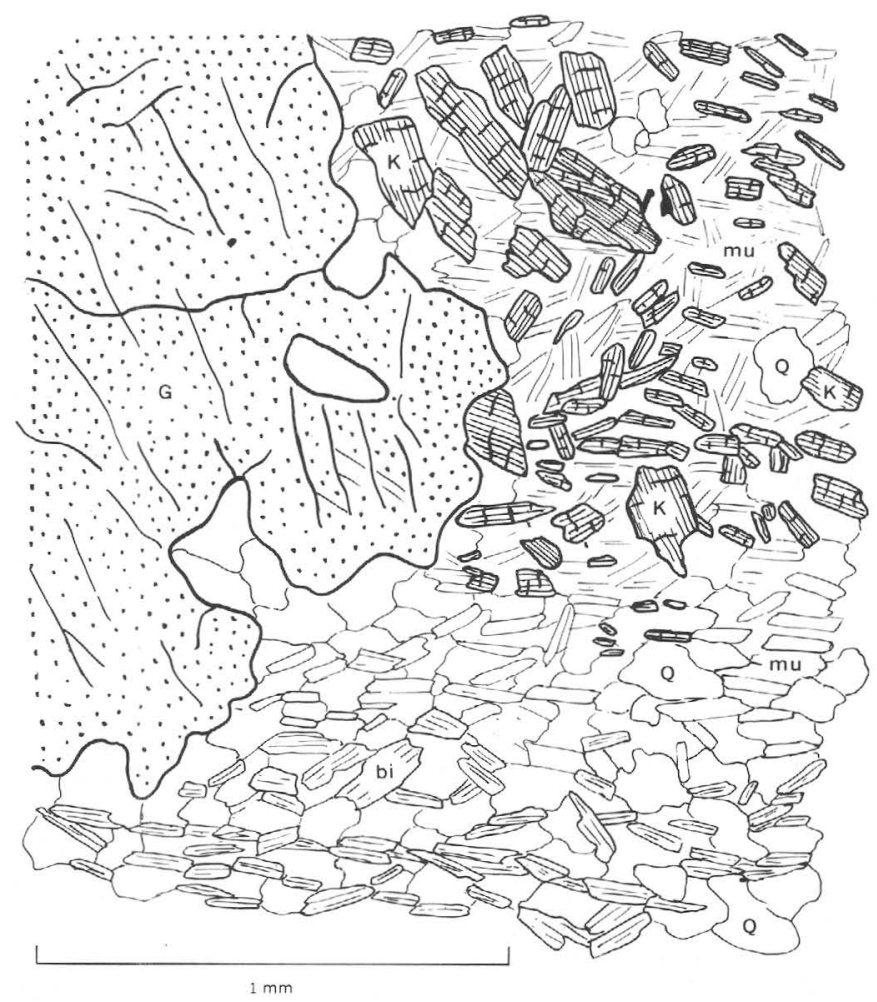

Frgdre 6.-Camera lucida drawing of a part of a nodule consisting of muscovite (mu) and kyanite $(K)$ in garnet-kyanite schist along the St. Maries River, 1 mile west of Gold Center (loc. 1615). Biotite (bi) occurs only in the lower part of the figure. Garnet (G), quartz (Q). $690-2370-63-3$
In other layers, garnet crystals are altered to chlorite and the nodules consist of muscovite without kyanite. Sphene is abundant along cracks where biotite is altered to chlorite. The titanium in this sphene was probably derived from the biotite. Apatite and tourmaline occur in tiny euhedral crystals about $0.1 \mathrm{~mm}$ and 2 to $5 \mathrm{~mm}$ long respectively.

In the quartzitic layers interbedded with the schist, the same minerals occur but in differing proportions. About 50 to 60 percent of the rock is quartz, and some plagioclase is common. The quartzitic layers also contain nodules of muscovite and kyanite, 1 to $2 \mathrm{~mm}$ long, but only in their mica-rich laminae.

The upper schist unit is very similar to the lower schist unit except that in some localities, for example on Bechtel Mountain, sillimanite is present instead of kyanite. On Bechtel Mountain, the schist is fine grained, thinly laminated and contains numerous garnet crystals, 1 to $5 \mathrm{~mm}$ in diameter (fig. $4 A$ ). Light-colored aggregates of sillimanite, 10 to $20 \mathrm{~cm}$ long and 1 to $2 \mathrm{~cm}$ wide, are randomly oriented along the bedding planes. The outlines of the aggregates resemble those of the kyanite on Anthony Peak, but the indices of refraction $a=1.654 \pm 0.002$ and $\gamma=1.677$ \pm 0.002 , indicate that they are sillimanite.

In typical schist from west of Clarkia, the micaceous laminae consist of tiny flakes of biotite, whereas the quartz-rich layers contain both muscovite and biotite. Garnet crystals have solid cores, but the rims have quartz inclusions as in fig. $4 A$. Garnets grow across the laminae and the micas around the garnets are only slightly bent. Cleavage makes an angle of about $35^{\circ}$ with the bedding plane. The muscovite flakes in the quartzitic layers are parallel to this cleavage, whereas many of the biotite flakes in the micarich laminae are parallel to the bedding.

In some layers clusters of large muscovite plates are pseudomorphs after an orthorhombic(?) mineral, probably andalusite. The best exposure of such layers is 2 miles west of Cedar Butte, just west of the mapped area (loc. 1851). The clusters of muscovite range from 1.5 to $2 \mathrm{~cm}$ in diameter and have square outlines. The individual muscovite plates in the clusters are about $0.5 \mathrm{~mm}$ thick, whereas the flakes of muscovite in the main part of the schist are less than $0.1 \mathrm{~mm}$ thick.

South and southeast of Clarkia, the grain size of the schist gradually becomes larger. The schist between Anthony Peak and Hemlock Butte is medium grained and contains abundant biotite and muscovite. On Anthony Peak crystals of red garnet, 5 to $15 \mathrm{~mm}$ in diameter, and prism-shaped clusters, 5 to $10 \mathrm{~cm}$ long, of tiny crystals of kyanite are embedded in a fine- 
grained micaceous groundmass. Biotite and muscovite flakes, 1 to $3 \mathrm{~mm}$ long, are interleaved. Muscovite also is in larger flakes 4 to $7 \mathrm{~mm}$ in diameter, that are oriented across the bedding planes.

In the schist on Hemlock Butte, sillimanite abounds but kyanite crystals are fewer and smaller than those on Anthony Peak. Brown biotite, in which $\gamma=1.653$ \pm 0.002 and which is riddled with tiny inclusions of zircon, is the dominant mica, the flakes ranging from 2 to $4 \mathrm{~mm}$ in diameter. Many layers contain only a few muscovite plates, all oriented across the plane of foliation. Nodules are common; some consist of sillimanite, others of small grains of quartz and kyanite, and still others of pegmatitic material. Sillimanite in the nodules is light brown, whereas the needles of sillimanite within and between the quartz grains and mica flakes are colorless. Irregularly shaped grains of magnetite are enclosed in the centers of some nodules.

Still farther south, in the vicinity of Elk Butte, Jackson Mountain, and Little Greek Mountain, the schist contains sillimanite but no kyanite or staurolite. Here the schist is coarse grained, the quartz grains ranging from 0.5 to $7 \mathrm{~mm}$ in diameter. In most layers there is more biotite than muscovite. The biotite flakes are of medium size and parallel to the plane of foliation, which is commonly parallel to the bedding. Some muscovite is interleaved with biotite and the remainder occurs as large plates that make an angle of $10^{\circ}$ to $40^{\circ}$ with the plane of foliation. These large plates include small quartz grains; conversely many small mica flakes are included in larger quartz grains. Some muscovite forms clusters in which flakes of medium size are oriented at random. Sillimanite is also common in these clusters, which thus correspond chemically to the nodules of muscovite and kyanite near Clarkia. Most of the schist contains 2 to 10 percent of garnet in crystals $1 / 2$ to $5 \mathrm{~mm}$ in diameter.

South of Little Green Mountain, a few layers, 20 to $50 \mathrm{~cm}$ thick, that consist of muscovite and a little. sillimanite and quartz are interbedded with the garnetsillimanite schist. In some places laminated layers rich in quartz are interbedded with the schist. These layers contain very little if any sillimanite or garnet, and the amount of quartz is 60 to $80^{\prime}$ percent. The grain size ranges from $1 / 2$ to $3 \mathrm{~mm}$. Every gradation exists from these quartz-rich layers to layers rich in micas, garnet, and sillimanite.

\section{THIN-BEDDED BIOTITE AND DIOPSIDE OR HORNBLENDE QUARTZITE AND GNEISS}

Both quartzite-gneiss units contain thin-bedded strata in which fine-grained layers of gray biotite quartzite (fig. $7 \mathrm{~A}$ ) alternate with some other layers that consist either of quartz with some plagioclase or of quartz, plagioclase, microcline, and diopside in about equal amounts. Where diopside is present the layers are light green, whereas the feldspar-bearing and pure quartzite layers are white or light bluish gray. Most

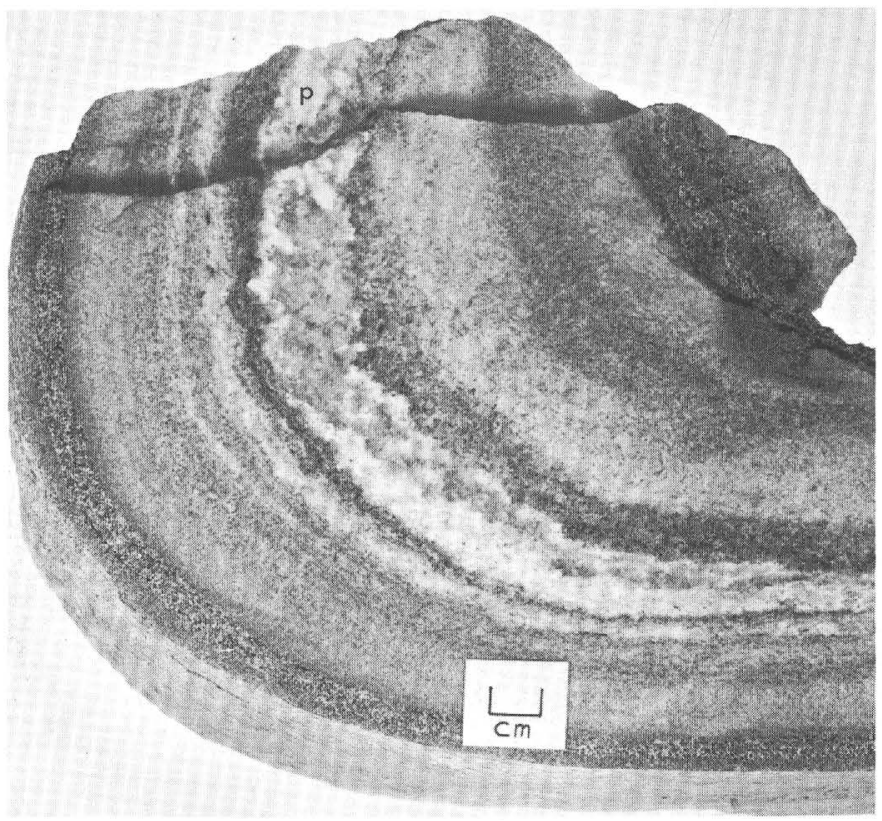

A. A fold in thin-bedded biotite quartzite along West Stony Creek (loc. 1521). Pegmatitic vein (P) parallels the bedding. The dark layers are rich in biotite.

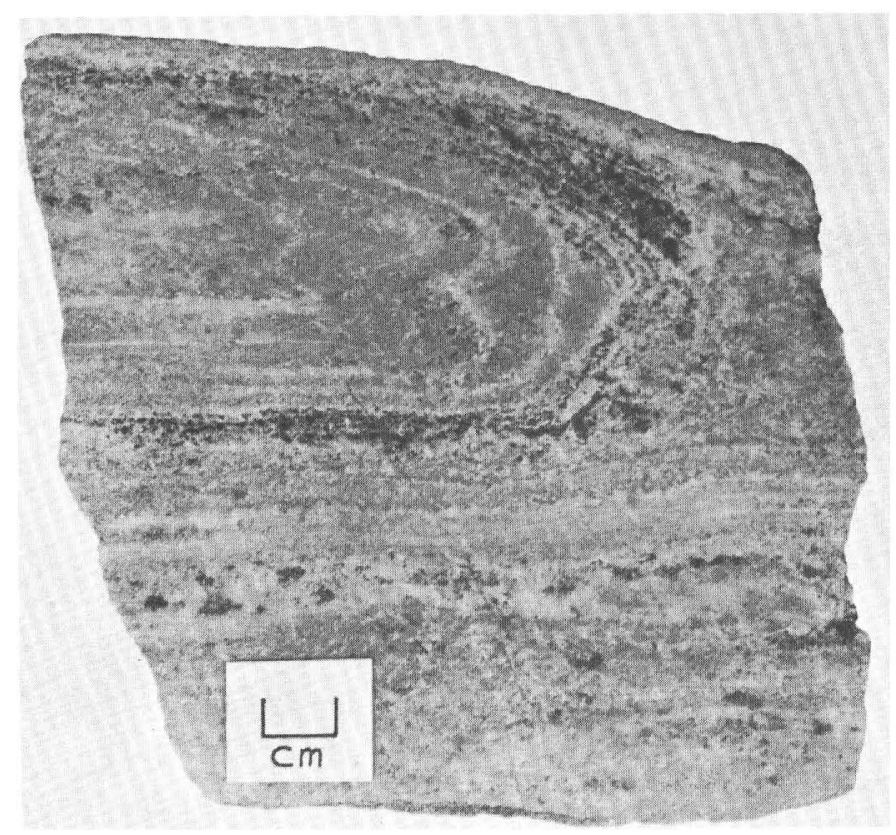

$B$. Diopside gneiss of the Wallace formation, with a thin layering and a small intraformational fold eaused by sliding of sediments (see p. C34). The dark spots are cavities from which calcite has weathered. Along the east Fork of Potlatch Creek just west of Bloom Meadows (1oc. 1262).

FigURE 7.-THIN-BEDDED BIOTITE GNEISS AND DIOPSIDE GNEISS OF THE WALLACE FORMATION. 
of the thin-bedded rocks in the lower quartzite-gneiss unit contain less diopside and more quartz than the thin-bedded layers in the upper quartzite-gneiss unit. The thin-bedded layers in the northern part of the area contain hornblende or actinolite instead of diopside.

The diopside-bearing layers in typical thin-bedded gneiss consist mainly of quartz, plagioclase, and diopside, with or without potassium feldspar and with a few small grains of biotite, sphene, apatite, and zircon. The light-colored constituents of most biotite-bearing layers include much potassium feldspar in addition to quartz and plagioclase. The texture of both diopsidebearing and biotite-bearing layers is granoblastic; the biotite flakes are parallel to the bedding (fig. 8) and the diopside occurs in small irregular-shaped grains. As a rule, light-green hornblende instead of diopside occurs in the corresponding layers north of Clarkia. The distribution of muscovite is highly irregular; most flakes occur in the thin micaceous laminae that are interbedded with biotite quartzite. Muscovite is rarely found in the thin biotite-bearing layers interbedded with diopside gneiss.

Many diopside- and hornblende-bearing beds in the northern and central part of the area contain scapolite and calcite. In some of these layers microcline is the main light-colored constituent; scapolite abounds and the amount of quartz is small. A measured mode of such layer in volume percents is: 47 percent diopside, 29 percent microcline, 18 percent scapolite, 3 percent quartz, 2 percent calcite, and 1 percent biotite.

In most of the other diopside- and hornblende-bear-

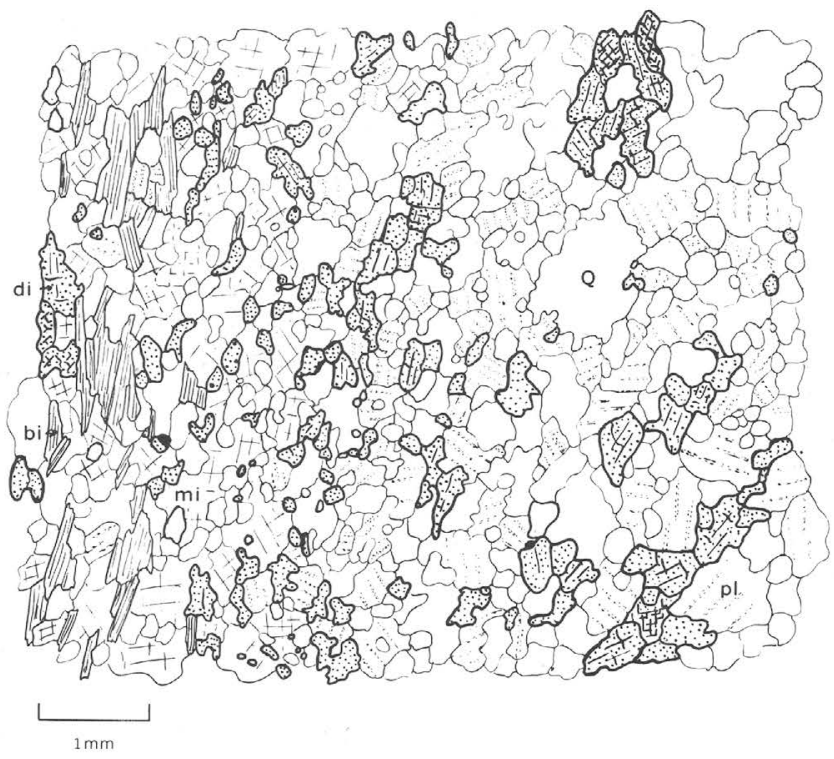

Figure 8.-Camera lucida drawing of a biotite-bearing layer in diopside gneiss along the East Fork of Potlatch Creek 1.8 miles east of the mouth of Mallory Creek (loc. 1246). Quartz (q), plagioclase (pl), microcline $(\mathrm{mi})$, diopside (di), biotite $(\mathrm{bi})$. ing beds in the northern and central part of the area, about half the feldspar is microcline and the other half albite $\left(A n_{5-10}\right)$, whereas in similar beds farther south the amount of microcline is negligible and the plagioclase ranges from andesine $\left(\mathrm{An}_{30}\right)$ to bytownite $\left(\mathrm{An}_{85}\right)$. In biotite-bearing layers also the plagioclase changes from albite in the northern part to oligoclase and andesine in the southern part of the area. The total amount of microcline also changes from north to south; it abounds in the northern part of the area but decreases southward, becoming negligible in most layers near the North Fork of the Clearwater River. Only a slight change occurs in the amounts of muscovite and biotite. The total amount of micas stays fairly constant but the amount of muscovite decreases and that of biotite increases toward the south.

The texture of the thin-bedded quartzite and gneiss suggests more intense recrystallization toward the south. In the northern part of the area, quartz and feldspar grains are round or slightly irregular in shape and average 0.1 to $0.2 \mathrm{~mm}$ in diameter. In contrast, in the southern part of the area the grains are fairly irregular with sutured or wavy borders and their diameter ranges from 0.1 to $3 \mathrm{~mm}$.

\section{DIOPSIDE GNEISS}

The diopside gneiss is banded, fine to medium grained, and grayish green. The thickness of the beds ranges from $5 \mathrm{~cm}$ to several meters, the thickness of 1 to $2 \mathrm{~m}$ being most common. The banding is due to the distribution of the constituent minerals, mainly to the abundance of diopside in laminae, 2 to $5 \mathrm{~mm}$ thick, and in part to the occurrence of calcite or biotite in certain thin laminae. Differential weathering is typical of the beds that contain calciterich laminae. Carbonate material, which may have been dolomitic, has weathered out, leaving cavities lined by hematite. In some layers diopside occurs in lens-shaped masses $5 \mathrm{~cm}$ thick and 10 to $20 \mathrm{~cm}$ long. These were probably dolomitic concretions in the original sedimentary rock. In the northernmost part of the area (for example, in loc. 1842) green hornblende and a little epidote, instead of diopside, crystallized in the presumed dolomitic layers.

In most layers of diopside gneiss the major constituents are quartz, plagioclase, microcline, and diopside, with or without scapolite, zoisite, clinozoisite, tremolite, hornblende, biotite, and calcite. The accessories are sphene, apatite, and magnetite. The hornblende that takes the place of diopside in the northernmost part of the area is pleochroic in pale green and light blue-green; in specimen 1910 it has $a=1.630 \pm 0.001, \beta=1.644 \pm 0.001, \gamma=1.652 \pm 0.001$. 
Light to dark-green prisms of tremolite and actinolite form the major portion of some layers near Clarkia. The amount of the major constituents shows local and regional variation. The local variation is visible as a more or less distinct banding (fig. $7 b$ ), caused mainly by distribution of dark constituents.

To study the local variation in detail, the mode was measured in typical specimens of fairly homogeneous diopside gneiss with differential weathering (table 4, column 1); in three adjacent thin layers of distinctly banded diopside gneiss (table 4, columns 2, 3, and 4, and fig. $9 a$ ) and in slightly banded diopside gneiss (table 4, column 5), all from the upper quartzitegneiss unit exposed along Potlatch Creek.

Comparison of the results (table 4, columns 1 to 5) shows an extensive variation in the amounts of the major constituents in the various layers of the diopside gneiss. The amount of diopside ranges from 16 to 49 percent, which gives rise to the visible banding. Variation in the amounts of the three light-colored constituents - quartz, plagioclase, and microcline-is even greater. Most layers contain 10 to 20 percent plagioclase but the amount of microcline varies from negligible to about 60 percent. Many layers rich in microcline contain only a small amount of quartz, whereas those poor in microcline are rich in quartz. Less plagioclase and microcline occur in layers rich in scapolite.

In many outcrops the layers, 1 to $3 \mathrm{~cm}$ thick and consisting of about 60 percent quartz, 30 percent scapolite, 10 percent diopside, and 10 percent calcite, alternate with other layers that range from 1 to $10 \mathrm{~mm}$ in thickness and consist of about 60 percent microcline, 30 percent quartz, 15 percent biotite, and 5 percent diopside. Abundant clinozoisite, which includes numerous tiny irregular-shaped grains of quartz, occurs with diopside in some scapolite-bearing quartz-rich layers.

Quartz-rich layers are prominent in an area south of Elk River where the gneiss has very little if any microcline (table 4, columns 6, 7, and 8). Most layers there are rich in quartz (table 4, column 6) ; many contain abundant plagioclase in addition to quartz and diopside (table 4, column 8). In some layers the $\mathrm{CaAlSi} \mathrm{O}_{8}$ component of plagioclase supplied material for zoisite (table 4, column 7 ).

To supplement the study of the distribution of potassium feldspar, volume percentages of the major constituents were estimated in a number of other gneissic layers collected from various parts of the lower and upper quartzite-gneiss units (tables 5 and 6 ). The results show a great variation in the amounts of major constituents of the diopside- and amphibole-bearing layers. Some of the samples of hornblende- and diopside-gneiss from the lower unit (locs. 1910, 1915,

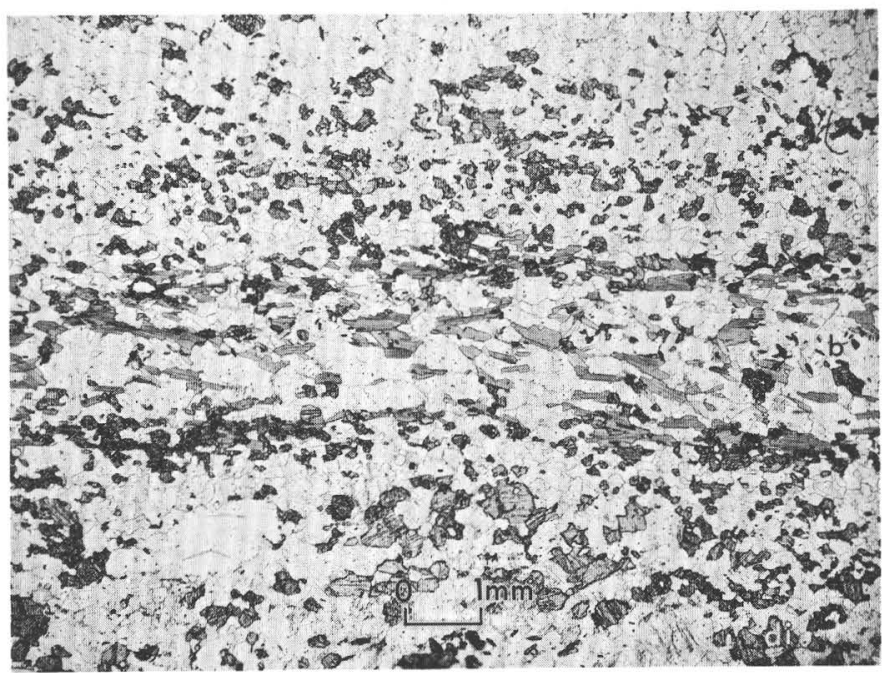

A. Biotite-rich laminae (b) in diopside gneiss. Along the East Fork of Potlatch Creek 1.8 miles east of the mouth of Mallory Creek (loc. 1246). Diopside (di), the light-colored minerals are quartz, plagioclase, and orthoclase. Plane-polarized light.

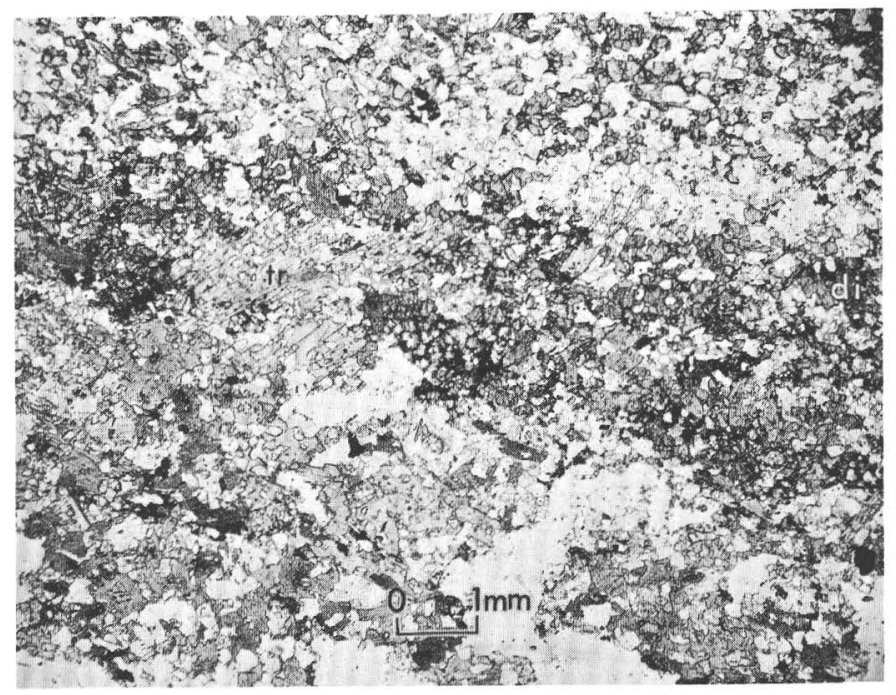

$B$. A layer of tremolite-diopside gneiss interbedded with garnet-mica schist on the ridge between Isabella and Breakfast Creeks (loc. 1444). Tremolite (tr), diopside (di). The light-colored minerals are mainly quartz and only about 10 percent bytownite. Plane-polarized light.

FIGURE 9.-PHOTOMICROGRAPHS OF BIOTITE LAMINAE AND TREMOLITE IN DIOPSIDE GNEISS IN THE WALLACE FORMATION.

$1610,1524,1445,2012,1468,2008,2005,1992)$ contain potassium feldspar in amounts ranging from 20 to 30 percent. Samples 1915 and 1524 are similar to numerous other layers in the northern part of the area. In the southern part only one specimen studied (No. 1992) has much potassium feldspar; in most layers this mineral is absent. The mineral content of the additional samples from the upper quartzite gneiss unit (table 6) confirms the finding that potassium feldspar is more abundant in the northern and central part of the area. 
METAMORPHISM OF BELT SERIES, ELK RIVER-CLARKIA AREA,

TABLE 4.-Measured mode in volume percentages of various layers of diopside gneiss along East Fork of Potlatch Creek and south Etk River.

\begin{tabular}{|c|c|c|c|c|c|c|c|c|c|c|}
\hline \multirow{2}{*}{ Location: } & \multicolumn{6}{|c|}{ East Fork of Potlatch Creek } & \multicolumn{2}{|c|}{ South of Elk River } & \multirow{2}{*}{$\begin{array}{c}\begin{array}{c}\text { North Fork of } \\
\text { Clearwater } \\
\text { River }\end{array} \\
9\end{array}$} & \\
\hline & 1 & 2 & 3 & 4 & 5 & 6 & 7 & 8 & & \\
\hline Rock: & $\begin{array}{l}\text { Diopside } \\
\text { gneiss } \\
\text { with } \\
\text { differ- } \\
\text { ential } \\
\text { weather- } \\
\text { ing }\end{array}$ & $\begin{array}{l}\text { Quartz-rich } \\
\text { layers, } 1.5 \\
\text { cm thick, } \\
\text { in banded } \\
\text { diopside } \\
\text { gneiss }\end{array}$ & $\begin{array}{l}\text { Biotite-rich } \\
\text { laminae, } 2 \\
\text { mm thick, } \\
\text { in banded } \\
\text { diopside } \\
\text { gneiss }\end{array}$ & $\begin{array}{c}\text { Layer be- } \\
\text { tween } 2 \\
\text { and } 3,1 \\
\text { mm } \\
\text { thick }\end{array}$ & $\begin{array}{l}\text { A verage } \\
\text { composi- } \\
\text { tion of } \\
\text { slightly } \\
\text { banded } \\
\text { diopside } \\
\text { gneiss }\end{array}$ & $\begin{array}{l}\text { Quartz- } \\
\text { rich } \\
\text { layer, } 1 \\
\text { cm } \\
\text { thick, in } \\
\text { diopside } \\
\text { gneiss }\end{array}$ & $\begin{array}{l}\text { Layer rich } \\
\text { in zoisite, } \\
1 / 2 \text { to } 1 \mathrm{~cm} \\
\text { thick }\end{array}$ & $\begin{array}{l}\text { Diopside- } \\
\text { plagioclase } \\
\text { gneiss }\end{array}$ & $\begin{array}{l}\text { Diopside- } \\
\text { plagioclase } \\
\text { gneiss }\end{array}$ & $\begin{array}{l}\text { Range of } \\
\text { the vol- } \\
\text { ume per- } \\
\text { centage } \\
\text { of con- } \\
\text { stituent } \\
\text { minerals }\end{array}$ \\
\hline Locality No.: & 1261 & 1246 & 1246 & 1246 & 1251 & 560 & 560 & 557 & & \\
\hline $\begin{array}{l}\text { Quartz } \\
\text { Plagioclase } \\
\text { Microcline } \\
\text { Scapolite } \\
\text { Zoisite } \\
\text { Diopside } \\
\text { Biotite } \\
\text { Calcite } \\
\text { Sphene }\end{array}$ & $\begin{array}{r}5 \\
1 \\
24 \\
15 \\
--49 \\
2 \\
4 \\
---4\end{array}$ & 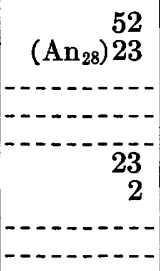 & $\begin{array}{r}20 \\
\left(\mathrm{An}_{28}\right)_{20} \\
20 \\
\hdashline-16 \\
24 \\
\hdashline-1 \\
\hdashline-10\end{array}$ & 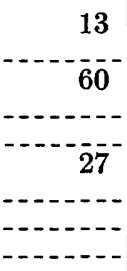 & $\begin{array}{r}\left(\mathrm{An}_{28}\right) 14 \\
11 \\
12 \\
1 \\
36 \\
\hdashline 13\end{array}$ & $\begin{array}{r}76 \\
\hdashline 3 \\
\hdashline \\
\hdashline \\
\hdashline \\
\hdashline\end{array}$ & \begin{tabular}{r}
31 \\
$\left(\mathrm{An}_{25}\right)^{8}$ \\
\hdashline-10 \\
\hdashline 15 \\
15
\end{tabular} & $\begin{array}{r}31 \\
\left(\mathrm{An}_{43-50}\right)^{38} \\
2 \\
\hdashline-18 \\
\hdashline-18\end{array}$ & $\begin{array}{r}30 \\
\left(\mathrm{An}_{85}\right){ }^{34} \\
\hdashline-10 \\
\hdashline-10 \\
\hdashline-10 \\
\hdashline-10\end{array}$ & $\begin{array}{r}5-76 \\
0-38 \\
0-60 \\
0-15 \\
0-35 \\
10-49 \\
0-24 \\
0-15 \\
0-1\end{array}$ \\
\hline Total _........ & 100 & 100 & 100 & 100 & 100 & 100 & 100 & 100 & 100 & 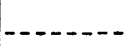 \\
\hline
\end{tabular}

TABLE 5.-Estimated volume percentage of major constituents in typical layers of the lower quartzite-gneiss unit of the Wallace formation

\begin{tabular}{|c|c|c|c|c|c|c|c|c|c|c|c|c|c|c|}
\hline Locality & Rock type & $\begin{array}{l}\text { 嘼 } \\
\text { 岁 }\end{array}$ & 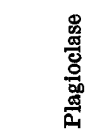 & & 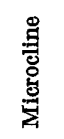 & 莣 & 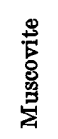 & 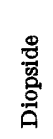 & $\begin{array}{l}\text { : } \\
\text { : } \\
\text { : } \\
\text { : } \\
\text { : }\end{array}$ & 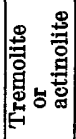 & 总 & 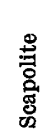 & 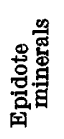 & Remarks \\
\hline 1910 & Hornblende gneiss...... & 2 & & 10 & 30 & & & & 40 & & & 15 & 3 & Inte \\
\hline 1913 & Thin-bedded biotite-plagio- & 45 & $\left(A n_{8}\right)$ & 35 & 5 & 10 & 5 & . & & & & & & 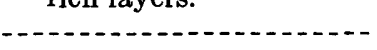 \\
\hline 1915 & Thin-bedded hornblende & 30 & & & 20 & 2 & & & 25 & & & 20 & 3 & \\
\hline 1908 & $\begin{array}{l}\text { gneiss with scapolite. } \\
\text { Thin-bedded muscovite } \\
\text { and biotite gneiss. }\end{array}\left\{\begin{array}{l}\mathrm{a} \\
\mathrm{b}\end{array}\right.$ & $\begin{array}{l}55 \\
55\end{array}$ & & 35 & 35 & 10 & 10 & & & & & & & $\begin{array}{l}\text { Layer b makes up about } \\
20 \text { percent of the total }\end{array}$ \\
\hline 1906 & $\begin{array}{l}\text { Thin-bedded biotite-plagi- } \\
\text { oclase gneiss. }\end{array}$ & 50 & & 35 & 2 & 10 & & & & & 3 & & & \\
\hline 1904 & $\begin{array}{l}\text { Scapolite- and calcite-bear- } \\
\text { ing biotite gneiss. }\end{array}$ & 53 & & 2 & & 15 & & & & & 20 & 10 & & \\
\hline 1917 & $\begin{array}{l}\text { Scapolite- and calcite-bear- } \\
\text { ing biotite-hornblende } \\
\text { gneiss. }\end{array}$ & 40 & 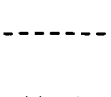 & - & 10 & 10 & & & 10 & & 10 & 20 & & \\
\hline 1 & Tremolite gneiss & 15 & $\left(\mathrm{An}_{5}\right)$ & 15 & & & & & & 70 & & & & \\
\hline & $\begin{array}{l}\text { Thin-bedded hornblende } \\
\text { gneiss. }\end{array}$ & 55 & $\left(A n_{30}\right)$ & 10 & & 5 & & & 25 & & & & 5 & Zoisite. \\
\hline $\begin{array}{l}1528 \\
1524\end{array}$ & Plagioclase gneiss & 55 & $\left(\mathrm{An}_{6}\right)$ & 35 & & 1 & 9 & & & & & & & \\
\hline & $\begin{array}{l}\text { Thin-bedded diopside and } \\
\text { hornblende gneiss. }\end{array}$ & 20 & & 20 & 20 & & & 20 & 20 & & & & $\ldots$ & $\begin{array}{l}\text { Diopside and hornblende } \\
\text { in separate thin layers. }\end{array}$ \\
\hline 1525 & White granular quartzite & 85 & & 10 & 4 & & & & & - & & & & \\
\hline & $\begin{array}{l}\text { IMlcrocline-ricn layer in } \\
\text { thin-bedded biotite gneiss. }\end{array}$ & 20 & $\left(\mathbf{A n}_{30}\right)$ & & bb & 10 & & & & & & & & \\
\hline & $\begin{array}{l}\text { Diopside-tremolite gneiss }- \text { - } \\
\text { Diopside-tremolite gneiss }\end{array}$ & 10 & & 15 & & 2 & & 20 & $-\cdots$ & 30 & 13 & & & \\
\hline & $\begin{array}{l}\text { lite gneiss } \\
\text { lite gneiss... }\end{array}$ & $\begin{array}{l}20 \\
20\end{array}$ & An & $\begin{array}{l}50 \\
45\end{array}$ & $\cdots$ & 5 & & $\begin{array}{l}15 \\
15\end{array}$ & --1 & $\begin{array}{l}15 \\
15\end{array}$ & & & & \\
\hline & Diopside-actinolite gneiss.-- & 35 & $\left(A n_{12}\right)$ & 35 & & & & 15 & 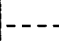 & 15 & --- & & $\ldots$ & Diopside and ac \\
\hline & Horr & 32 & (A) & 3 & & & & 5 & 25 & & & & & 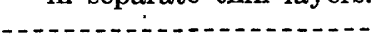 \\
\hline & Diopside-actinolite gneiss_-- & 15 & & & 25 & & & 10 & & 10 & & & & \\
\hline
\end{tabular}


TABLE 6.-Estimated volume percentage of major constituents in typical layers of the upper quartzite-gneiss unit of the Wallace

\begin{tabular}{|c|c|c|c|c|c|c|c|c|c|c|c|}
\hline Locality & Rock type & Quartz & Plagioclase & Microcline & Biotite & Diopside & Hornblende & Calcite & Scapolite & $\begin{array}{l}\text { Epidote } \\
\text { minerals }\end{array}$ & $\underset{\text { site }}{\text { Clinozoi- }}$ \\
\hline $1885 \ldots$ & Diopside-hornblende & 40 & $(A n) 30$, & 20 & & 7 & 3 & & & & \\
\hline 1886 & Biotite gneiss & 20 & 20 & 37 & 20 & $\ldots$ & 2 & & & $\mathbf{1}$ & \\
\hline 1889 & Thin-bedded biotite & 30 & & 5 & 15 & & & & & & \\
\hline 1919 & Diopside gneiss...- & 52 & $\left(\mathrm{An}_{50}\right) \overline{8}$ & $\begin{array}{l}50 \\
10\end{array}$ & 10 & 20 & & & & 10 & \\
\hline 1920 & $\begin{array}{l}\text { Diopside-hornblende } \\
\text { gneiss }\end{array}$ & 35 & $\left(A n_{5}\right) 35$ & & & 10 & 20 & & & & \\
\hline 1435 & $\begin{array}{l}\text { Thinly laminated diop- } \\
\text { side and biotite } \\
\text { gneiss }\end{array}$ & 20 & $\left(\mathrm{An}_{32}\right) 20$ & & 10 & 50 & & & & & \\
\hline 1433 & Diopside gneiss & 35 & $\left(\mathrm{An}_{8}\right) \quad 50$ & & - & 15 & & & & & \\
\hline $\begin{array}{l}1437 \\
1260\end{array}$ & $\begin{array}{l}\text { Diopside gneiss } \\
\text { Thin-bedded diopside } \int \mathrm{a}\end{array}$ & $\begin{array}{l}30 \\
60\end{array}$ & $\left(\mathrm{An}_{22}\right) 30$ & & & $\begin{array}{l}40 \\
10\end{array}$ & & 10 & 20 & & \\
\hline & and biotite gneiss. $\{b \mid$ & 20 & -- & 60 & 15 & 5 & & & & & \\
\hline 1262 & Diopside gneiss & 40 & 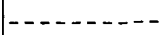 & & & 30 & & & 20 & 10 & \\
\hline & $\begin{array}{l}\text { Dcaponte-protite } \\
\text { gneiss }\end{array}$ & 30 & 25 & & 20 & & & & 25 & & \\
\hline 1940 & Diopside gneiss_....... & 20 & 40 & 10 & & 25 & & & & 5 & \\
\hline
\end{tabular}

None of the diopside-plagioclase gneiss layers studied from the Boehls Butte quadrangle and from the area south of plate 1 contain potassium feldspar and certainly these layers correspond to the lower and upper quartzite-gneiss units of the present area (Hietanen, 1962, and 1963). In the Headquarters quadrangle (southeast of the present area) only one sample of diopside gneiss and another of thin-bedded biotiteand diopside-plagioclase gneiss are rich in potassium feldspar. Most of the diopside-plagioclase gneiss layers east and south of the present area consist of quartz, plagioclase, and diopside in about equal amounts. Thus there seems to be a definite decrease in the number of microcline-bearing layers and increase in plagioclase-bearing layers toward the south and southeast. Because the amount of micas stays fairly constant, this means a decrease in the total amount of potassium and increase in sodium toward the south and southeast parallel to the regional structural trend. Before it can be concluded whether this lateral change in composition of diopside and hornblende gneiss is due to initial differences in the original strata or to a later metasomatic exchange of alkalies during metamorphism, the textural relations and the composition of the adjoining layers must be considered.

The distribution of diopside shows a considerable lateral variation, which, however, is quite different from that of potassium feldspar. The total amount of diopside is fairly constant over the central and southern part of the area, but in the individual beds the content of diopside is highly variable. For instance, the gneiss layers east and west of Gold Butte contain abundant diopside, but the amount of this mineral decreases toward the south, and the corresponding layers along the North Fork of the Clearwater River consist exclusively of white granular quartzite with rather thin beds of biotite gneiss.

An exceptionally large amount of diopside (about 50 percent) occurs in some granular light green layers of thinly laminated diopside-biotite gneiss at the head of Mallory Creek (table 6, No. 1435). The paper-thin laminae that separate the diopside-rich layers, 2 to 10 $\mathrm{mm}$ thick, consist of light brown mica with $\gamma=1.590$ \pm 0.005 and small $2 \mathrm{~V}$; pleochroism is $\mathrm{Z}=$ light brown, $\mathrm{X}=$ very light tan. These optical properties suggest this mica to be closest to phlogopite.

In many gneissic layers in the northern half of the central part of the mapped area abundant tremolite or actinolite occurs instead of diopside (table 5, No. 1610 ) or with the diopside (locs. 1468, 2008, 2012, and fig. $9 b)$. These tremolite- and actinolite-rich diopside gneisses are especially common near Gold Center but also occur along the ridge between Isabella Creek and Breakfast Creek and along Gold Creek.

All layers in the northernmost part of the area contain green hornblende instead of actinolite and diopside (table 5, Nos. 1910, 1915, 1917) or with the diopside (table 6, No. 1885). Clinozoisite and zoisite are common additional constituents, and plagioclase is albitic.

Some bytownite-bearing layers east of Gold Butte contain grossularite in anhedral crystals that measure 1 to $5 \mathrm{~mm}$ in diameter and include numerous tiny round quartz and plagioclase grains. Diopside grains in this rock are larger and more irregular in shape than those in the other layers.

The textures of three specimens of diopside gneiss from the upper quartzite-gneiss unit are shown on figures 10-12. Figure 10 is a camera lucida drawing 
from a banded diopside gneiss along the East Fork of Potlatch Creek, figure 11 shows a layer of diopside quartzite south of Elk River, and figure 12 is diopsideplagioclase gneiss along the North Fork of the Clearwater River. In all three specimens the texture is granoblastic and the grain size varies within fairly narrow limits. Diopside occurs as small rounded or angular grains or groups of grains between the lightcolored constituents. Along the East Fork of Potlatch Creek and near the North Fork of the Clearwater River most of the quartz grains are small and round; many of them are included in the other minerals. In the layers exceptionally rich in quartz, such as No. 560 south of the town of Elk River, the quartz has recrystallized as irregularly shaped, large grains with slightly sutured borders. Most of the microcline and plagioclase occur as small rounded or irregularly shaped grains (figs. 10 and 12) with quartz, but a few larger grains include one or two, rarely more, of the small round quartz grains. These textures are similar to those of isochemically metamorphosed sediments. Specifically, no replacement textures that would in-

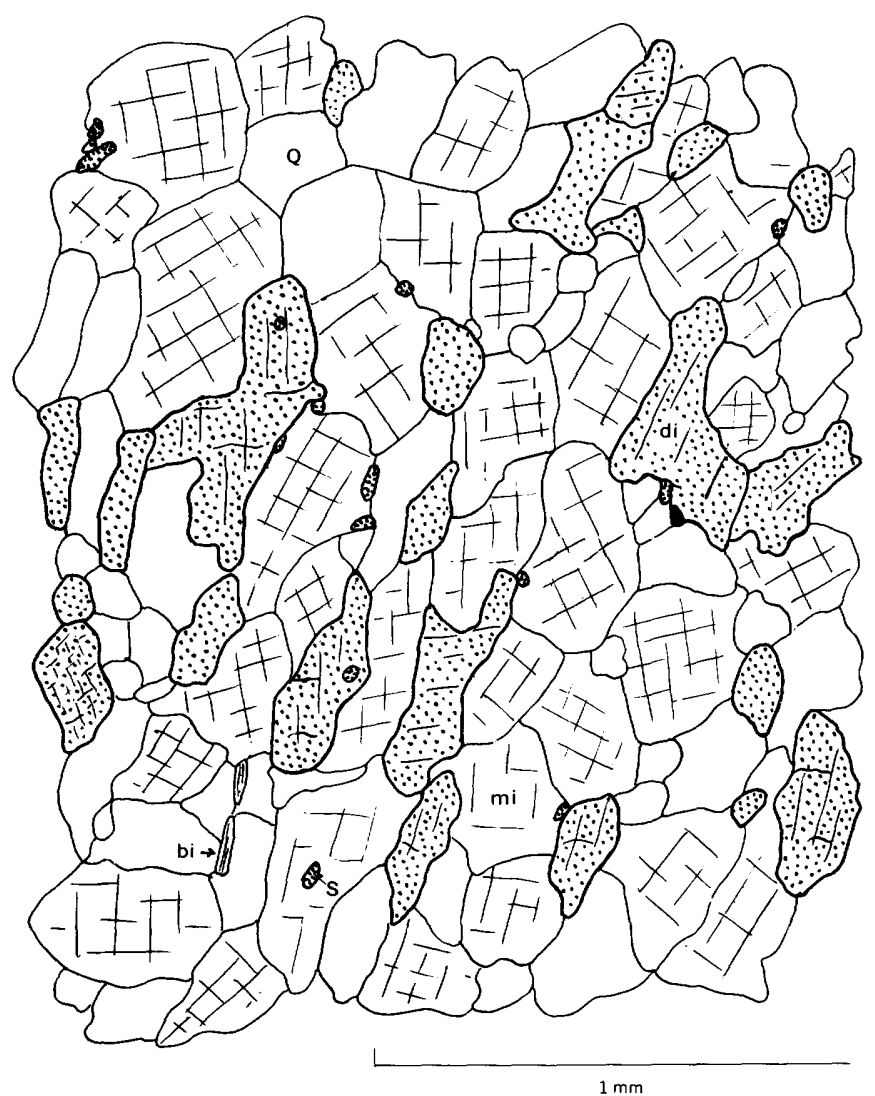

Figdr 10.-Camera lucida drawing of diopside gneiss along the East Fork of Potlatch Creek, 1.7 miles east of the mouth of Mallory Creek (loc. 1248). Diopside (di) occurs as small rounded grains between larger quartz $(Q)$ and microcline (mi) grains. Biotite (bi), sphene (S) Note abundance of microcline.

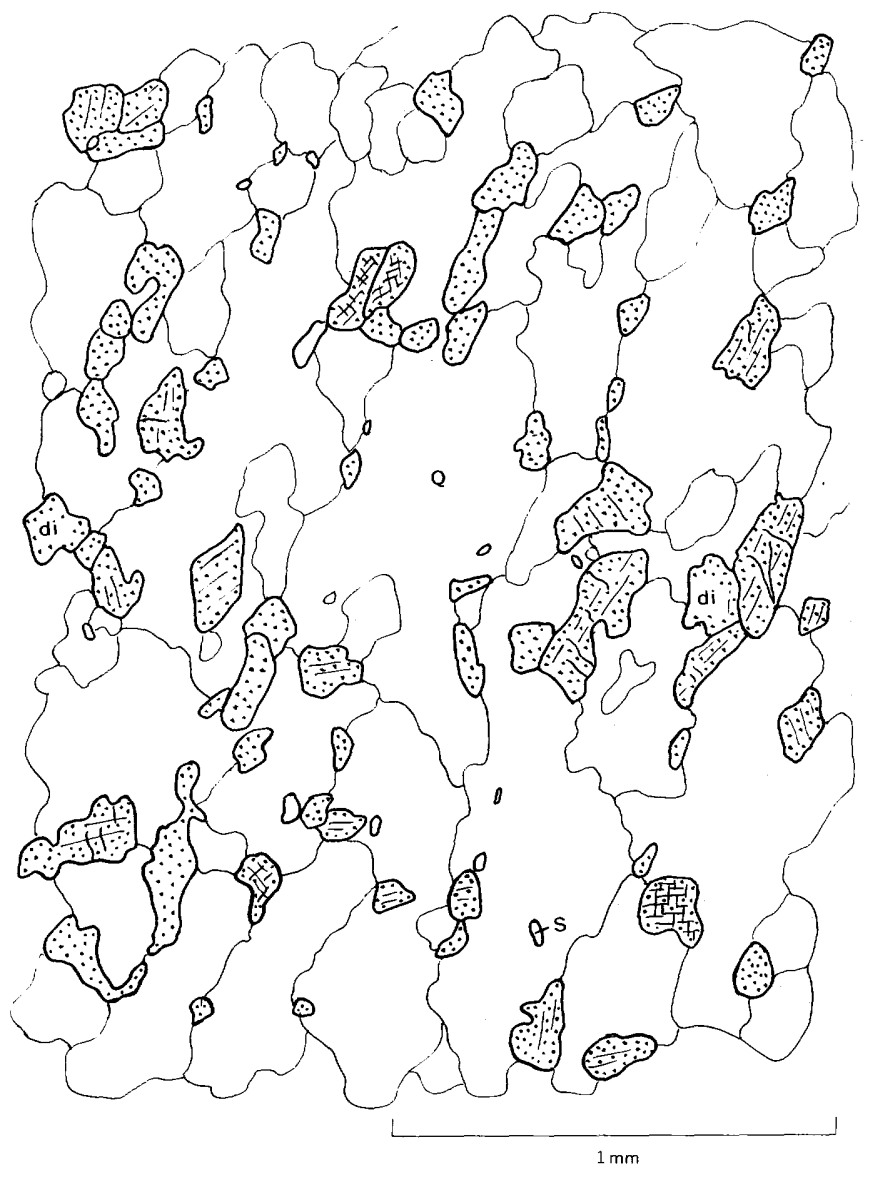

Figdre 11.-Camera lucida drawing of diopside quartzite, 4.7 miles south of Elk River along the county road leading from Dent to Elk River. This rock lacks potassium feldspar: Quartz (Q), diopside (di), sphene (S).

dicate a late introduction of potassium were found near the East Fork of Potlatch Creek.

The diopside-plagioclase gneiss near the North Fork of the Clearwater River has a granoblastic equigranular texture typical of isochemically metamorphosed sedimentary rocks. A part of these diopsideplagioclase gneisses, however, has undergone metasomatic changes that altered the diopside into hornblende and generally increased the amount of plagioclase and decreased that of quartz. These metasomatic changes took place after the major period of recrystallization, as has been earlier described from an area south and southeast of the Elk River-Clarkia area (Hietanen, 1962). Signs of similar metasomatism are rare in the southeastern part of the area.

\section{WHITE GRANULAR QUARTZITE}

The third kind of layer that can easily be identified in the field consists of white granular rocks fairly rich in quartz but locally containing large amounts of feldspars. The individual beds, which range from 2 to 30 
$\mathrm{cm}$ in thickness, are separated by micaceous layers, a few millimeters to several centimeters thick. In some localities in the northern part of the area, light-gray micaceous quartzite layers are interbedded with the white granular quartzite. Near the North Fork of the Clearwater River thin layers of medium-grained biotite-plagioclase gneiss are interbedded with white granular quartzite representing the more highly metamorphosed equivalent of the gray layers.

In the upper quartzite-gneiss unit along the East Fork of Potlatch Creek and its tributaries scattered individual light-green grains of diopside or small groups of grain give a spotted appearance to many layers that are interbedded with white granular quartzite. In some outcrops the small grains of green diopside occur in greater numbers in layers, 1 or $2 \mathrm{~cm}$ thick, that separate the pure quartzite layers, which range from 5 to $15 \mathrm{~cm}$ in thickness.

In several localities light-colored layers of the upper quartzite-gneiss unit have relict crossbedding. This crossbedding becomes visible because the tiny grains of green diopside are in rows that make an angle with the overlying bed and join the underlying layer asymptotically. Crossbedding has been described from the sandy layers of the Wallace formation in the

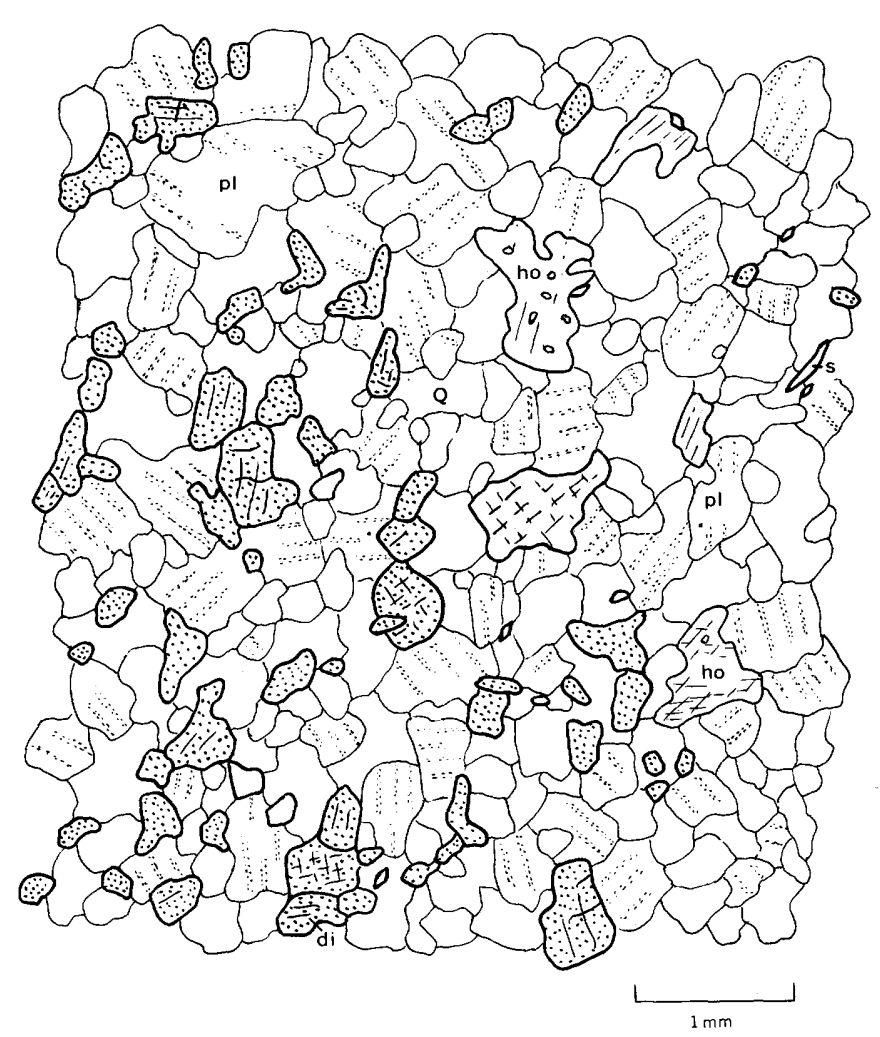

Figdre 12.-Camera lucida drawing of diopside-plagioclase gneiss along the North Fork of the Clearwater River (in lower right corner of pl. 1). Quartz (Q), plagioclase (pl), Diopside (di), hornblende (ho), sphene $(S)$. This rock has no potassium feldspar.
Coeur d'Alene district by Ransome and Calkins (1908, p. 41) as follows:

The weathered surfaces are as a rule pure white $* * *$ upon these surfaces, when they have been long exposed to the etching action of atmospheric water, a beautiful cross-bedded structure appears, of which no trace is visible upon fresh fractures

and the etched material was suggested to be mainly calcite. Near Elk River, crystallization of diopside in the corresponding layers indicates that the carbonate was mainly dolomite. Crossbedding is conspicuous also in fresh surfaces, because of the contrasting color of the white quartz-feldspar rock and the green diopside. Ransome and Calkins described the sandstones with crossbedding to be characteristic of the middle part of the Wallace formation. Near Elk River this structure appears in the middle part of the upper quartzite-gneiss unit above the beds of diopside gneiss. This horizon would thus correspond to the calcareous quartzite of the middle division in the threefold division by Ransome and Calkins (1908, p. 40).

A microscopic study of the white granular quartzite reveals a considerable variation in composition between the individual layers. Most layers are rich in quartz, the percentage of this mineral ranging from 60 to 85 (table 5, No. 1525), but in some layers the amount of albitic plagioclase $\left(\mathrm{An}_{6-15}\right)$ may be considerable (about 25 to 55 percent, fig. $13 A$ ). A small amount ( 3 to 6 percent) of untwinned potassium feldspar is present in these layers. Small grains of brown rutile and zircon occur as accessories.

Muscovite with some biotite or diopside and actinolite are the additional constituents in many layers interbedded with the white granular quartzite; the amount of these minerals ranges from negligible to 20 percent. In contrast to the diopside gneiss, the diopside-bearing layers of the white granular quartzite contain very little potassium feldspar.

In many quartz-rich layers the quartz grains are much larger ( 1 to $2 \mathrm{~mm}$ in diameter) than the albite grains $(0.1$ to $0.2 \mathrm{~mm}$ in diameter) and the mica flakes ( 0.2 to $0.4 \mathrm{~mm}$ in diameter). The quartz grains are strongly deformed (fig. 13B) and have sutured borders, whereas the feldspar grains (albite and microcline) occur either rounded or as elongated grains between the quartz grains. In the layers rich in albite, quartz occurs in small round grains and albite fills the interstices. The mica flakes are included in the quartz grains or occur between them. The diopside occurs either as scattered individual grains with rounded corners or small groups of irregular-shaped grains very similar to those in the diopside gneiss. Microcline occurs either as scattered grains with albite or as large grains in certain 


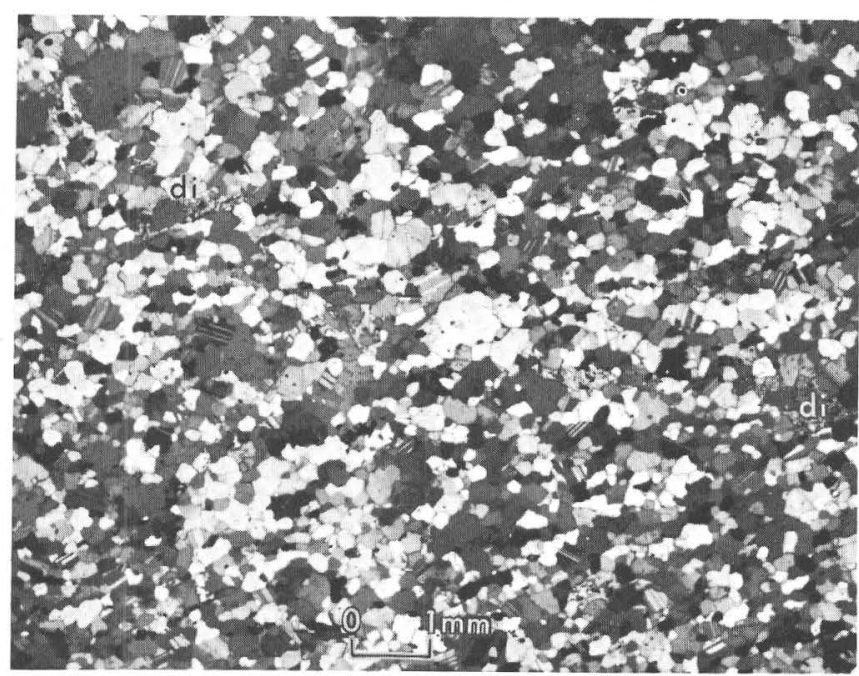

A. White granular quartzite containing albitic plagioclase with albite twinning. A few small grains of diopside (di) occur as additional constituents. Texture is granoblastic. This layer is interbedded with biotite quartzite along the east fork of Potlatch Creek about 0.5 mile north of Bloom Meadows. Crossed nicols.

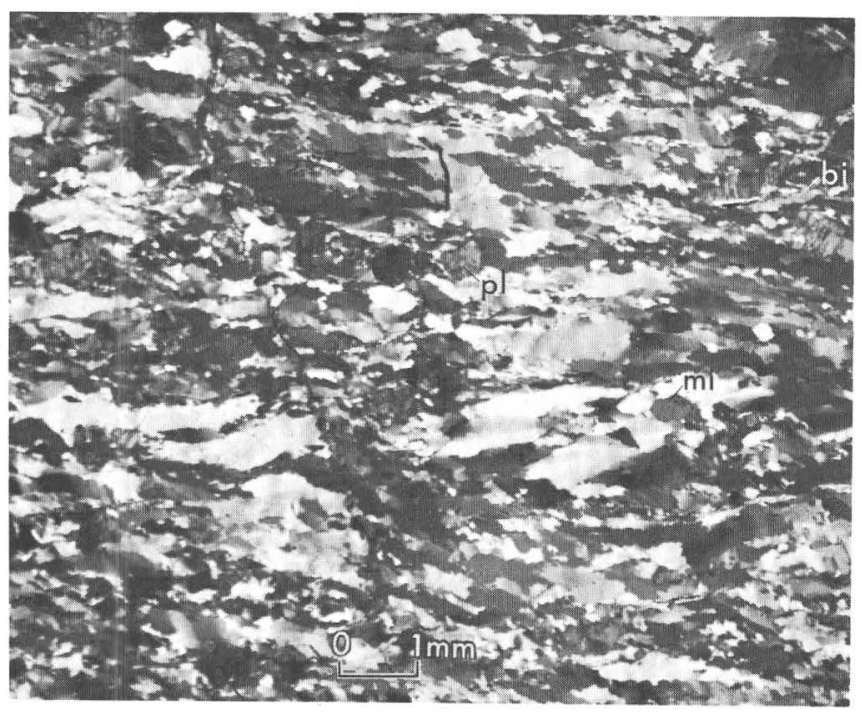

B. A strongly deformed layer in white granular quartzite along the St. Maries River 1.1 miles south of Gold Center (loc. 1525). About 3 percent plagioclase in small round or elongated grains, 1 percent orthoclase in elongated grains, and 1 percent biotite in small flakes occur among the quartz grains. Plagioclase (pl), microcline (mi), biotite (bi). Crossed nicols.

Figdre 13.-PHOTOMICROGRAPHS OF WHITE GRANULAR QUARTZITE IN THE WALLACE FORMATION.

thin layers. These large grains are elongated parallel to the bedding and include round quartz and albite grains.

In its mean composition the white granular quartzite is fairly uniform throughout the mapped area. The plagioclase is albitic also in the southernmost part; in most layers it ranges from $\mathrm{An}_{5}$ to $\mathrm{An}_{12}$ and constitutes from 10 to 50 percent of the rock.

$690-2370-63-4$
THIN-BEDDED BIOTITE QUARTZITE AND GNEISS

Thin-bedded layers of biotite- and plagioclase-bearing light- to medium-gray quartzite and gneiss form a large proportion of the lower quartzite-gneiss unit. The uppermost part of the upper quartzite-gneiss unit consists mainly of beds of white to light-gray plagioclase quartzite 2 to $10 \mathrm{~cm}$ thick separated by thin biotite-bearing layers; layers of thin-bedded gray quartzite rich in biotite, and thus similar to the thinbedded biotite quartzite of the lower unit, are interbedded also in the upper unit.

The amounts of the four major constituents of the biotite gneiss are highly variable: quartz, 20 to 60 percent; plagioclase, 12 to 50 percent; potassium feldspar, 0 to 60 percent; and biotite, 2 to 25 percent. Numbers 1913, 1908, 1906, and 1520 on table 5 and Nos. 1886 and 1889 on table 6 are representative of this rock type. The dark layers are rich in biotite. The light layers are rich either in quartz and plagioclase or in quartz and potassium feldspar (fig. 14A). In some outcrops the plagioclase-rich layers form the major part of the rock and the potassium feldspar occurs only in some thin layers (2 to $3 \mathrm{~mm}$ thick) interbedded with thicker plagioclase-rich layers (5 to $10 \mathrm{~mm}$ thick). In some other outcrops, however, the ratio between the thicknesses of the plagioclase- and the potassium feldsparrich layers is about one to four. Layers that contain both feldspars in about equal amounts are also interbedded. Muscovite occurs with biotite in some paperthin mica-rich laminae that separate the layers (1 to $2 \mathrm{~cm}$ thick), consisting of light-colored quartz-feldspar rock with only a small amount of biotite.

The amount of potassium feldspar decreases toward the south; the composition of the biotite gneiss is in this respect comparable to that of the diopside gneiss. All specimens studied along the East Fork of Potlatch Creek have abundant potassium feldspar. In the vicinity of Elk River, the layers rich in potassium feldspar are few and thin, and near the North Fork of the Clearwater River only one contains potassium feldspar. This specimen is from a fine-grained biotite gneiss layer, $3 \mathrm{~cm}$ thick, interbedded with biotite schist, and contains about 40 percent quartz, 40 percent plagioclase, 30 percent microcline, and very little biotite. Microcline in this rock occurs as large grains that include many small round quartz grains. In the common biotite gneiss near the North Fork of the Clearwater River, plagioclase $\left(\mathrm{An}_{12}\right)$ forms about 65 percent of the rock, the amount of quartz is about 25 percent, and that of biotite, muscovite, and accessories combined, about 10 percent. These compositions suggest that the biotite gneiss is the metamorphosed equivalent of arkosic layers. Some of these layers were inter- 


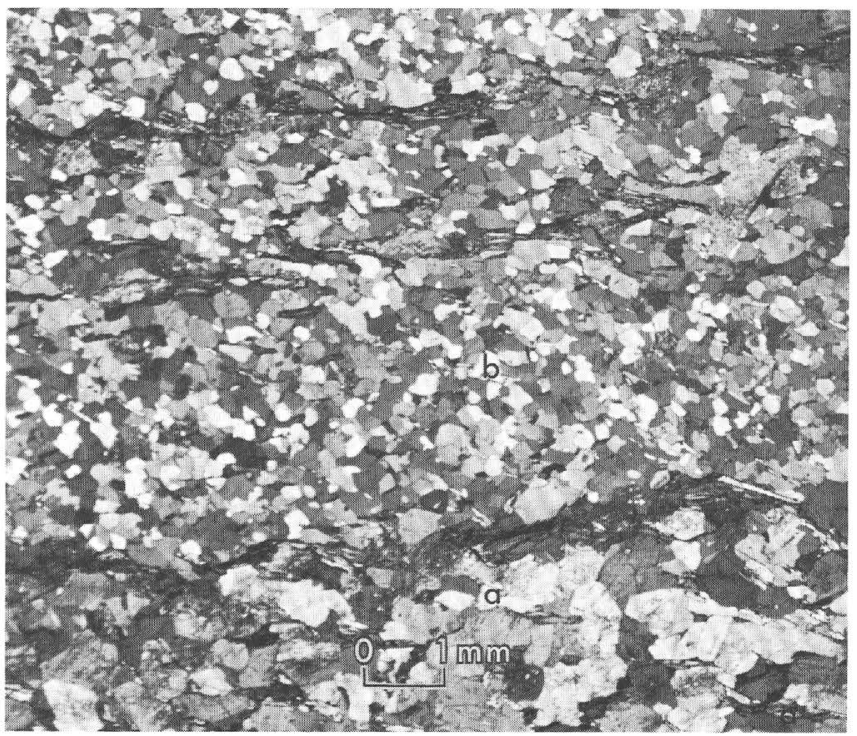

A. Thin-bedded biotite gneiss along Stony Creek, 3 miles east of Hemlock Butte (loc. 1520). Layer a consists of plagioclase with only a few tiny grains of quartz and flakes of biotite; layer $b$ is rich in untwinned potassium feldspar and contains small grains of quartz (white). Most of the biotite occurs in the thin laminae (dark) and is partly altered to chlorite with inclusions of rutile and leucoxene. Crossed nicols.

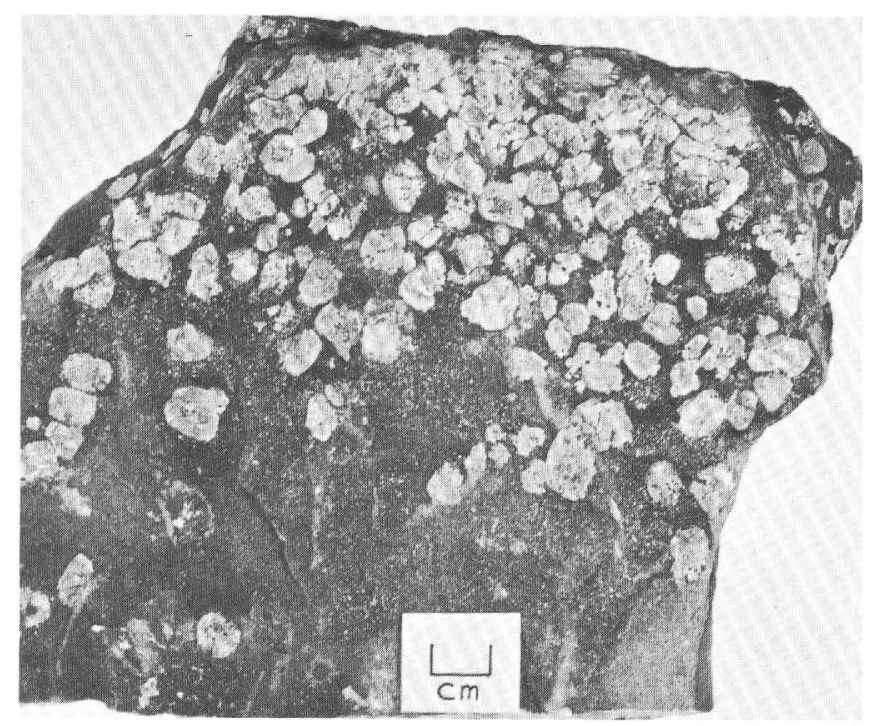

$B$. Light-colored round scapolite crystals in dark fine-grained biotite gneiss at Incline Lookout (just north of the northern boundary of pl. 1).

FIGURE 14.-PHOTOMICROGRAPH OF BIOTITE GNEISS AND PHOTOGRAPH OF ROUND SCAPOLITE GRAINS IN BIOTITE GNEISS IN THE WALLACE FORMATION.

bedded with quartzites and dolomitic sandstones, but most of them represent transitional phases between the argillaceous layers and the quartzites or the dolomitic sandstones.

The texture of the biotite gneiss exposed in the northern part of the area differs from that of the gneiss in the southern part. In the northern part the gneiss is fine grained, the quartz occurs in small ( 0.1 to $0.2 \mathrm{~mm}$ in diameter) rounded grains and the feldspars fill the interstices. The small flakes of biotite are between the other minerals or grow through them; most of the biotite flakes are oriented parallel to the bedding, but a few make an angle of about $20^{\circ}$ with this plane. Toward the south the grain size becomes larger. Near Elk River the quartz and feldspar grains range from 0.5 to $2 \mathrm{~mm}$ in diameter and the mica flakes from 1 to $2 \mathrm{~mm}$ in length. Near the North Fork of the Clearwater River the majority of the quartz and plagioclase grains are 1 to $2 \mathrm{~mm}$ in diameter and the mica flakes may be as much as $3 \mathrm{~mm}$ in diameter. As a rule, the mica flakes in the biotite-rich laminae have a diameter that is two or three times that of the biotite in the light-colored layers.

In some localities the biotite gneiss contains scapolite in large- to medium-size white crystals (for example locs. 1904, 1438). This mineral is more common in the northern part than in the southern part of the area; thick layers very rich in large round scapolite grains occur just north of the northern border (fig. 14B).

The scapolite grains in a layer 1 mile south of Bloom Meadows (fig. 15A) contain numerous small inclusions of quartz and a few grains of epidote (fig. 15A). Indices of refraction of scapolite in specimen 1438 are $\epsilon=1.547 \pm 0.002, \omega=1.575 \pm 0.002$ indicating that this scapolite is mizzonite with 55 percent meionite (Winchell and Winchell, 1951, p. 353). Biotite in this specimen is strongly pleochroic, with $\mathrm{Y}=\mathrm{Z}=$ reddish brown and $\mathbf{X}=$ straw color; it has $\gamma=1.611 \pm 0.002$ and $2 \mathrm{~V}=0^{\circ}$. A considerable amount of plagioclase and potassium feldspar occur in this rock.

Along the north-central boundary of the area the scapolite is dipyre with about 45 percent meionite $(\epsilon=1.546 \pm 0.002, \omega=1.566 \pm 0.002)$. Biotite is strongly pleochroic with $\mathrm{Z}=$ light brown, $\mathbf{X}=$ straw color, $\gamma=$ $1.641 \pm 0.002$, and $-2 \mathrm{~V}=3^{\circ}$. Epidote, calcite, brown rutile, and zircon are the additional constituents in the scapolite-bearing layers.

\section{SOME CONCLUSIONS BASED ON OPTICAL PROPERTIES OF MINERALS IN THUW WALLACE FORMATION}

To find out whether or not the composition of the constituent minerals such as biotite, diopside, and amphiboles varies, the optical properties of these minerals were determined in several specimens from various parts of the area. In many layers of the schist, gneiss, and quartzite, biotite is the only ferromagnesian mineral, and it can therefore give an approximate value for the iron-magnesium ratio in the rock. In the diopside gneiss, the diopside usually 


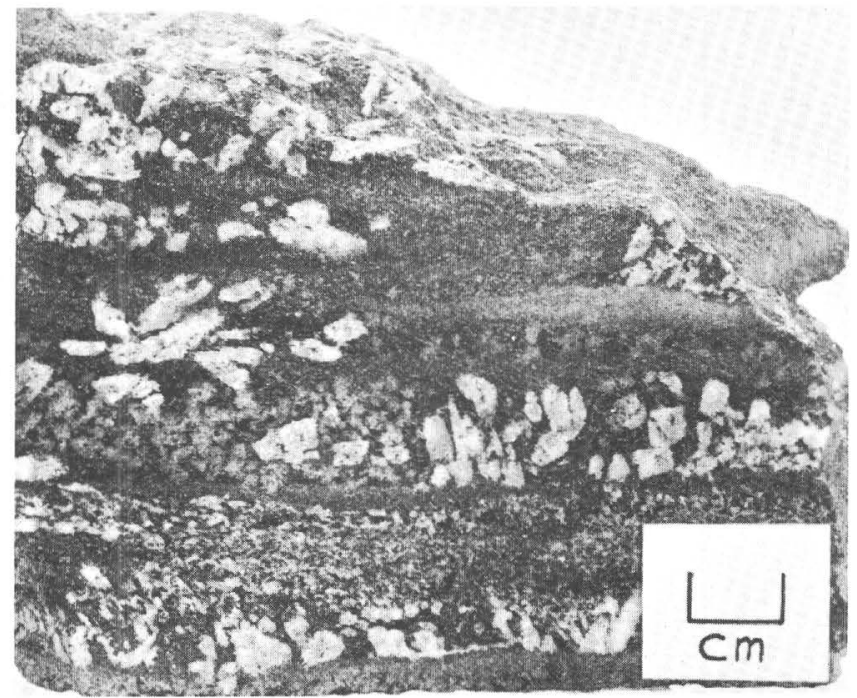

A. A hand specimen of a scapolite-bearing biotite gneiss about one mile south of Bloom Meadows (loc. 1438). The white angular crystals are scapolite.

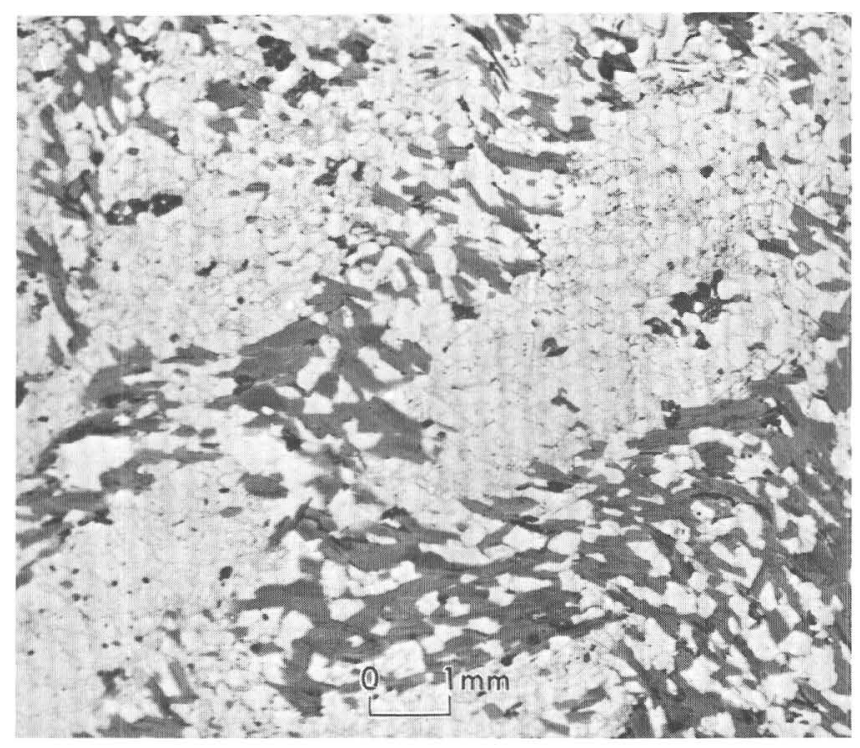

$B$. Photomicrograph of the rock shown in figure $15 \mathrm{~A}$. The scapolite grains are light colored and contain small round inclusions of quartz. The rock between the scapolite grains consists of quartz, plagioclase, orthoclase, and biotite. Crossed nicols.

FIgURE 15.-PHOTOGRAPH AND PHOTOMICROGRAPH OF SCAPOLITE-BEARING LAYER IN BIOTITE GNEISS OF THE WALLACE FORMATION.

includes all the iron and magnesium present and serves as a similar indicator.

The optical properties of biotites taken from different environments vary considerably but the biotites from petrographically similar layers are similar. All biotites are strongly pleochroic with $Z=$ brilliant brown and $\mathrm{X}=$ straw color; the optic angles are close to zero. The $\gamma$ index was measured in several specimens, and the values on table 7 show its variation in the biotites from various layers of the Wallace formation. The index of refraction of the biotite in the schist is slightly higher than that of the biotite in the quartzite and gneiss. This higher index of refraction suggests that the biotite in the schist is richer in iron. The biotite in the diopside and hornblende-bearing gneiss and in some of the scapolite-bearing layers has a considerably lower index of refraction, which suggests that the biotite in these layers is rich in magnesium. In all the biotites $-2 \mathrm{~V}$ is small.

The values of $\gamma$ on table 7 are arranged in geographic order, each column starting from the north and ending in the south. Comparison of the values within each column suggests that there is no regular geographic variation in the composition of biotite, even though in the schist the index tends to be higher in the southern part of the area, suggesting a composition richer in iron.

TABLE 7. Index of refraction of biotite in various layers of the Wallace formation

\begin{tabular}{|c|c|c|c|c|c|c|c|c|c|}
\hline \multicolumn{2}{|c|}{ Schist } & \multicolumn{2}{|c|}{$\begin{array}{l}\text { Biotite-quart- } \\
\text { zite and } \\
\text { gneiss }\end{array}$} & \multicolumn{2}{|c|}{$\begin{array}{l}\text { Scapolite- } \\
\text { bearing } \\
\text { biotite } \\
\text { gneiss }\end{array}$} & \multicolumn{2}{|c|}{$\begin{array}{l}\text { Diopside- } \\
\text { biotite } \\
\text { gneiss }\end{array}$} & \multicolumn{2}{|c|}{$\begin{array}{l}\text { Hornblende } \\
\text { gneiss }\end{array}$} \\
\hline 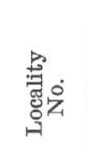 & 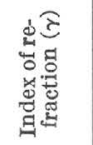 & 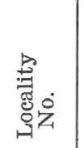 & 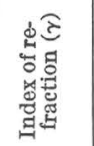 & 急 & 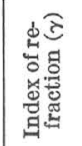 & 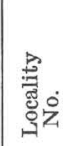 & 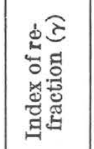 & 局 & 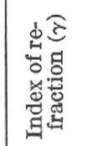 \\
\hline $\begin{array}{r}1851 \\
1429 \\
1441 \\
566\end{array}$ & $\begin{array}{l}\text { 1. } 637 \\
\text { 1. } 643 \\
\text { 1. } 650 \\
1.651\end{array}$ & $\begin{array}{r}1909 \\
1616 \\
1521 \\
1183 \\
255\end{array}$ & $\begin{array}{l}\text { 1. } 633 \\
1.637 \\
1.630 \\
1.643 \\
1.625\end{array}$ & $\begin{array}{l}1789 \\
1438 \\
----\end{array}$ & 1. 641 & $\begin{array}{r}1246 \\
1435 \\
1445 \\
-\end{array}$ & $\begin{array}{l}1.610 \\
1.590 \\
1.587 \\
-\end{array}$ & \begin{tabular}{r}
1885 \\
1886 \\
1527 \\
\hdashline-0 \\
-0
\end{tabular} & \begin{tabular}{l} 
1. 606 \\
1. 607 \\
1.625 \\
\hdashline-
\end{tabular} \\
\hline \multicolumn{2}{|c|}{$\begin{array}{l}50-60 \\
\text { percent } \\
\text { iron } \\
\text { members }\end{array}$} & \multicolumn{2}{|c|}{$\begin{array}{l}40-55 \\
\text { percent } \\
\text { iron } \\
\text { members }\end{array}$} & & & & & & \\
\hline
\end{tabular}

Localities:

18512 miles west of Cedar Butte.

1429 Hemlock Butte.

566 Jackson Mountain.

$\begin{aligned} 566 & \text { Little Green Mountain } \\ 1909 & \text { Along Merry Creek }\end{aligned}$

1909 Along Merry Creek

1521 Along West Stony Creek, 3 miles east of Hemlock Butte.

11832.7 miles east of Jackson Mountain.

255 North Fork of Clearwater River.

1787 Incline Lookout (just north of the mapped area).

14381.9 miles north of Jackson Mountain.

1246 Along East Fork of Potlatch Creek, about 1.6 miles west of Mallory Creek. 1435 Head of Mallory Creek.

1445 About 3 miles northeast of Elk Butte.

1885 West-northwest of Cedar Butte.

1527 Along St. Maries River, south of Gold Center.

The indices of refraction of hornblende, tremolite, actinolite, diopside, biotite, scapolite, and epidote minerals were measured in several specimens and are shown on table 8 in geographic order, the northernmost samples appearing on the top of the list. The estimated volume percentages of minerals for these samples are given on tables 5 and 6 . 
The indices of refraction of hornblende and diopside are fairly uniform suggesting that there is very little variation in the chemical composition of these minerals. The mean values for the hornblende are $a=$ $1.637, \gamma=1.656, \gamma \wedge c=23^{\circ}$. Comparison with the optical properties of a large number of hornblendes given by Winchell (1945, p. 42-43) and Hallimond (1943) suggest that the average hornblende near Clarkia is optically close to the light-green hornblende first described by Beskow $(1929$, p. 73) and later referred to by Kulling (1933, p. 341, No. 14) from Gabbi, N.
Storfjället, Swedish Lappland. Calculation of the formula from the chemical analysis of this hornblende gives the following result:

$\left(\mathrm{Na}_{0,79} \mathrm{~K}_{0,10} \mathrm{Ca}_{1,88}\right)_{\Sigma=2,72}\left(\mathrm{Mg}_{2,89} \mathrm{~F}_{20.22}^{++3} \mathrm{Ti}_{0,11} \mathrm{Fe}_{1.21}^{+2} \mathrm{Al}_{0,54}\right)_{\Sigma=4,97}$ $\left(\mathrm{Al}_{1,22} \mathrm{Si}_{6,78}\right)_{\Sigma=8,0}\left(\mathrm{OH}_{1,76} \mathrm{O}_{22,24}\right)_{\Sigma=24,0}$,

or in the generalized form:

$(\mathrm{O}, \mathrm{OH}, \mathrm{F})_{2} \mathrm{Na}_{0-1}(\mathrm{Ca}, \mathrm{Na})_{2} \mathrm{Mg}_{3}\left(\mathrm{Mg}, \mathrm{Fe}, \mathrm{Ti}^{+4}, \mathrm{Fe}^{+3}, \mathrm{Al}\right)_{2}$ (Al, $\mathrm{Si}) \mathrm{Si}_{7} \mathrm{O}_{22}$

in which $\mathrm{Mg} / \mathrm{Fe}=2.39$.

TABLE 8.-Optical properties of minerals in the amphibole-and diopside-bearing gneiss of the Wallace formation

\begin{tabular}{|c|c|c|c|c|c|c|c|}
\hline Locality No. & Rock type & Hornblende & $\begin{array}{l}\text { Tremolite or } \\
\text { actinolite }\end{array}$ & Diopside & Biotite & Scapolite & $\begin{array}{l}\text { Clinozoisite } \\
\text { or zoisite }\end{array}$ \\
\hline $1910_{-}$ & Diopside-hornblende gneiss ... & $\begin{aligned} \alpha & =1.630 \\
\beta & =1.644 \\
\gamma & =1.652 \\
\gamma \wedge c & =23^{\circ} \\
\alpha & =1.633\end{aligned}$ & & & $\gamma=1.606$ & $\begin{array}{l}\omega=1.564 \\
\epsilon=1.546\end{array}$ & \\
\hline 1917 & $\begin{array}{l}\text { Scapolite- and calcite-bearing } \\
\text { biotite-hornblende gneiss. }\end{array}$ & $\begin{aligned} \gamma \wedge c & =23^{\circ} \\
\alpha & =1.633 \\
\gamma & =1.652\end{aligned}$ & & & $\gamma=1.632$ & $\begin{aligned} \omega & =1.561 \\
\epsilon & =1.542\end{aligned}$ & \\
\hline $1610_{-}$ & Tremolite gneiss.............. & 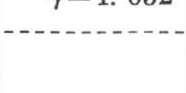 & $\begin{array}{l}\alpha=1.607 \\
\beta=1.618 \\
\gamma=1.631\end{array}$ & & & & \\
\hline 1919 & Diopside gneiss & & $1-1.001$ & $\begin{array}{l}\alpha=1.680 \\
\beta=1.686 \\
\gamma=1.705\end{array}$ & & & $\begin{array}{l}\alpha=1.713 \\
\beta=1.715 \\
\gamma=1.721\end{array}$ \\
\hline 1920 & Diopside-hornblende gneiss _. - & $\begin{aligned} \alpha & =1.640 \\
\gamma & =1.664 \\
\gamma \wedge c & =19^{\circ}\end{aligned}$ & $\ldots$ & $\begin{array}{l}\alpha=1.681 \\
\gamma=1.705\end{array}$ & & & $---1-1$ \\
\hline 1437 & Diopside gneiss_.-- & & & $\begin{array}{l}\alpha=1.682 \\
\beta=1.687 \\
\gamma=1.707\end{array}$ & & & \\
\hline 1527 & $\begin{array}{l}\text { Thin-bedded hornblende } \\
\text { gneiss. }\end{array}$ & $\begin{array}{l}\alpha=1.634 \\
\gamma=1.656\end{array}$ & & 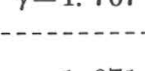 & $\gamma=1.625$ & & $\begin{array}{l}\alpha=1.693 \\
\gamma=1.698\end{array}$ \\
\hline 1445 & Diopside-tremolite gneiss _.... & 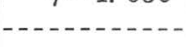 & $\alpha=1.610$ & $\alpha=1.671$ & $\gamma=1.587$ & & 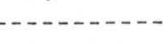 \\
\hline 2012 & Diopside-tremolite gneiss_..- & & $\begin{array}{l}\gamma=1.634 \\
\alpha=1.608 \\
\gamma=1.632\end{array}$ & $\begin{array}{l}\gamma=1.696 \\
\alpha=1.673 \\
\beta=1.681 \\
\gamma=1.701\end{array}$ & & & \\
\hline 1468 & Diopside-actinolite gneiss_. & & $\begin{array}{l}\alpha=1.618 \\
\beta=1.634 \\
\gamma=1.642\end{array}$ & $\begin{array}{l}\alpha=1.674 \\
\gamma=1.700\end{array}$ & & & \\
\hline 2008 & Diopside-actinolite gneiss._._. & 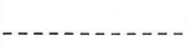 & $\alpha=1.618$ & $\alpha=1.679$ & -- & & \\
\hline 2005 & Hornblende gneiss. & $\begin{array}{l}\alpha=1.631 \\
\gamma=1.651\end{array}$ & $\gamma=1.642$ & $\begin{array}{l}\gamma=1.704 \\
\alpha=1.682 \\
\gamma=1.705\end{array}$ & & & \\
\hline
\end{tabular}

In samples from the northernmost part of the area (for example No. 1910), the indices of refraction of hornblende are somewhat lower than the average values near Clarkia; in samples from the southern part they tend to be higher, which indicates that the magnesium-iron ratio ranges from about 2.4 to 4.0 (Winchell and Winchell, 1951).

The minerals of the tremolite-actinolite series occur in light- to dark-green prisms and show a slight variation in optical properties. The indices of refraction range as follows: $\alpha=1.607$ to 1.618 ; and $\gamma=1.631$ to 1,642 , which indicates that the composition ranges from a very pure tremolite to an actinolite end member containing about 10 percent iron.
The diopside that occurs with tremolite shows slightly lower indices of refraction $(a \approx 1.672)$ than the diopside of the tremolite-free layers $(a \approx 1.690)$. In the actinolite-bearing layers the indices of refraction of diopside also tend to become higher with the increase of the indices of actinolite. This indicates an approximately equal distribution of the increase of iron between the diopside and the amphibole. The optical properties of the diopside show that its composition ranges from a fairly pure magnesium end member to a diopside containing about 15 percent of iron end member (Winchell and Winchell, 1951, p. 413). Thus all diopsides are rich in magnesium, which together with the composition of the other ferromagnesian min- 
erals show that the original sediment was dolomitic with only a minor amount of iron. In the hornblendeand biotite-bearing layers, the iron content of the metasedimentary rock is somewhat higher-as indicated by a higher iron-magnesium ratio in hornblende $(1::)$ and in biotite $(1: 5$ to $1: 2)$.

In most layers of the quartzite-gneiss units the diopside, amphiboles, and biotite are the chief carriers of iron and magnesium and the iron-magnesium ratio of these minerals reflects the iron-magnesium ratio of the original sediment. From the study of the minerals it can be concluded that in the layers of diopside gneiss and hornblende gneiss, which is metamorphosed equivalents of dolomitic sandstones, the molecular ironmagnesium ratio is about $1: 5$ and $1: 3$, respectively. In the biotite-bearing layers (originally quartzitic and shaly layers) the same ratio varies from $1: 4$ to $1: 1$; and in the common mica schist, which contains about 10 percent almandite and 20 percent biotite, the ironmagnesium ratio is about $3: 2$. The schist layers are equivalent to the slates and blue-gray argillites of the Coeur d'Alene district.

The chemical analyses made of the corresponding layers of the Wallace formation in the Headquarters quadrangle (which lies southeast of the area under discussion) show the following iron-magnesium ratios: 1: 3 in diopside-plagioclase gneiss, $1: 1$ in biotite gneiss, $2: 1$ and 5:2 in schist (Hietanen, 1962, table 2, Nos. 289, 248, 246, 247).

Another difference in the chemical composition between the mineralogically different layers of the Wallace formation is the variation in the content of potassium and aluminum as reflected in the distribution of biotite. Many horizons consist of remarkably thin beds of diopside gneiss alternating with biotite quartzite and biotite gneiss (fig. 3) ; this indicates an original rapid and sharp compositional variation. Growth of fairly large crystals of high-grade metamorphic minerals such as diopside, garnet, sillimanite, kyanite, and biotite has made this compositional variation strikingly visible.

\section{METAMORPHIC FACIES OF THE BELT SERIES}

The abundance of pelitic and calcareous material in the Wallace formation near Elk River and Clarkia makes this formation especially useful for the study of variation in the degree of metamorphism. The distribution of index minerals such as muscovite, biotite, garnet, staurolite, kyanite, sillimanite, epidote, hornblende, and diopside provides means of following the changes in the relative temperature-pressure field of the recrystallization. The various units of the Wallace formation extend over the whole area from the northwest corner to the southeast, allowing possible changes in the mineral assemblages of each unit to be followed over a distance of about 25 miles. The metamorphic grade increases slightly from northwest to southeast. The area can be divided into three parts, each with a characteristic metamorphic grade, as indicated by typical mineral assemblages in the schists and gneisses: (1) the northern part, north and northeast of Clarkia ; (2) the central part, between Anthony Peak and Hemlock Butte; and (3) the southern part, south of Hemlock Butte.

The common mineral assemblages in various layers in the schist exposed in the northern part of the area (T. $43 \mathrm{~N}$. across the map, pl. 1) are as follows:

1. (Andalusite) - almandite - biotite - muscovitealbite-zoisite-quartz.

1b. (Andalusite) - almandite - biotite - muscovite quartz.

2. Muscovite - biotite - microcline - albite - clino zoisite-quartz.

2a. Muscovite - biotite - albite - clinozoisite - quartz with or without scapolite.

2b. Muscovite - biotite - microcline - plagioclase $\left(A n_{8}\right)$-quartz.

Quartzo-feldspathic layers have the mineral assemblage:

2c. Biotite - microcline - epidote - plagioclase $\left(A n_{8-10}\right)$-quartz.

Epidote is stable with hornblende and albitic plagioclase in the garnet amphibolite with the following mineral assemblages:

3. Hornblende - almandite - biotite - epidote -pla gioclase $\left(\mathrm{An}_{10}\right)$-quartz.

3a. Hornblende - almandite - epidote - plagioclase $\left(\mathrm{An}_{10}\right)$ - quartz.

Hornblende-biotite gneiss which is common in the area has the following mineral assemblage:

3b. Biotite - hornblende - epidote - plagioclase $\left(A n_{10-15}\right)$ - quartz.

Mineral assemblages in the gneissic layers are as follows:

4a. Hornblende - biotite - microcline - calcite quartz.

5. Hornblende - biotite - microcline - clinozoisite plagioclase $\left(\mathrm{An}_{5-15}\right)$ - quartz.

5a. Hornblende-biotite-microcline-quartz.

6. Hornblende - microcline - calcite - clinozoisite plagioclase $\left(\mathrm{An}_{5-15}\right)$ - quartz.

6a. Hornblende - microcline - (clinozoisite) - plagio clase $\left(\mathrm{An}_{5-15}\right)$ - scapolite - quartz.

7a. Hornblende - biotite - calcite - scapolite - quartz.

7b. Biotite - calcite - epidote - albite - scapolite quartz.

8a. Biotite-microcline-calcite-albite-quartz.

9a. Microcline-biotite-tremolite-(albite)-quartz. 
These mineral assemblages indicate the conditions of the biotite-almandite subfacies of the epidote-amphibolite facies. Occurrence of andalusite would indicate a higher temperature subfacies.

In addition to aluminum- and calcium-rich minerals, abundant microcline, muscovite, and biotite occur in many layers and make it necessary to include potassium in graphic presentation. On the other hand; ferromagnesian minerals form an essential part of the rocks. Iron substitutes only for a small portion of magnesium in diopside, hornblende, and biotite, whereas the garnets are mainly iron-aluminum compounds. In the graphic presentation, iron and magnesium can be considered together and the number of the essential components is reduced to the following four: $A=$ aluminum, $\mathrm{C}=$ calcium, $\mathrm{F}=$ ferrous iron + magnesium + manganese, and $\mathrm{K}=$ potassium. On figures $16-18$, these four components are plotted at the corners of a compositional tetrahedron, within which the compositions of minerals are represented by appropriate atomic ratios. For example, the point for muscovite $(\mathrm{OH})_{2}$ $\mathrm{KAl}_{3} \mathrm{Si}_{3} \mathrm{O}_{10}$ divides the $\mathrm{AK}$ edge of the tetrahedron in the ratio $1: 3$, and that for microline in the ratio $1: 1$. The composition of biotite analyzed from the schist in the nearby Boehls Butte quadrangle (Hietanen, 1963) was used to find the point for the biotite. The points for biotite and phlogopite are on the AKF face and those for hornblende on the ACF face, which is the back face of the tetrahedron.
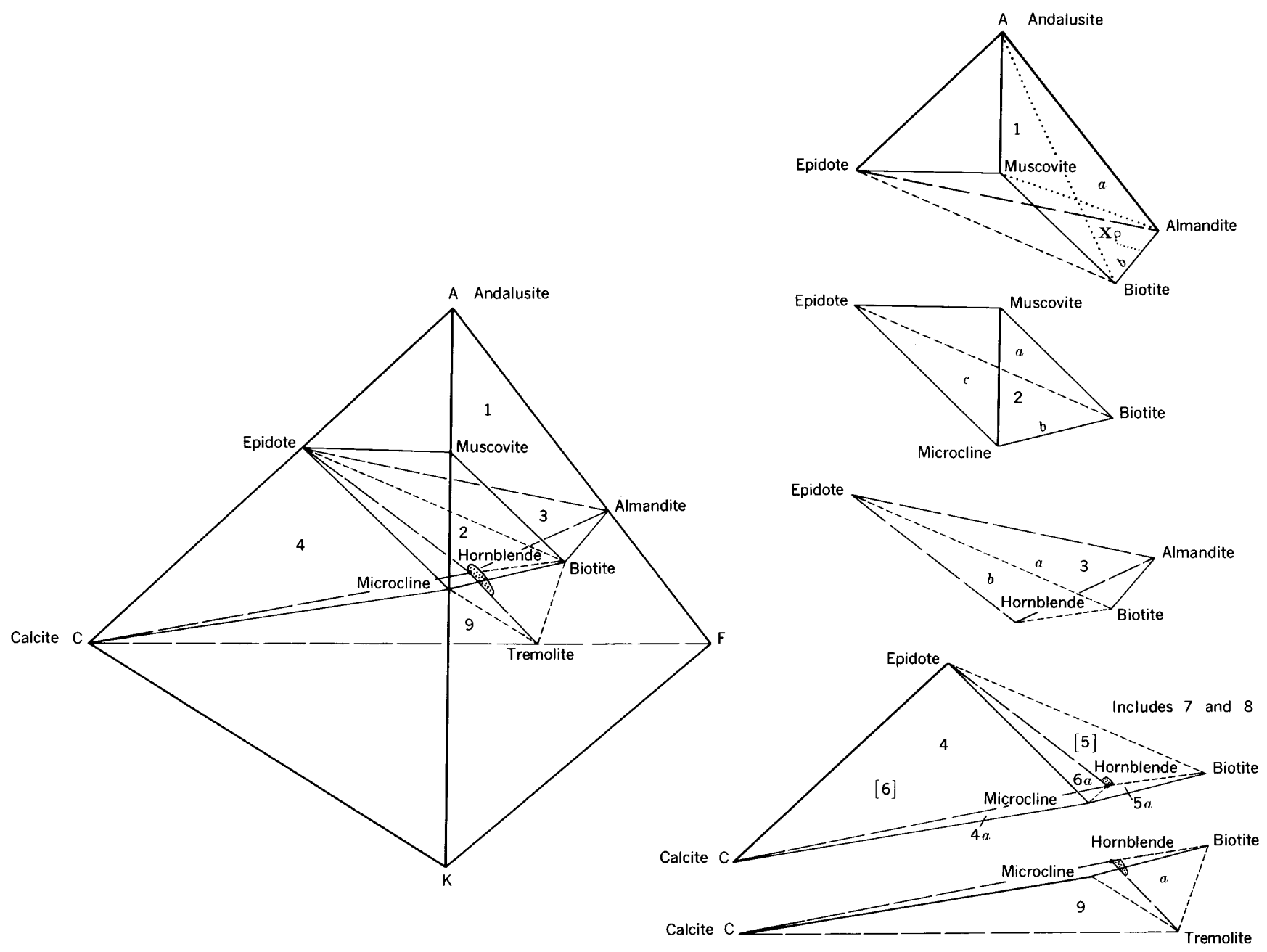

Figdre 16.-ACFK diagram for the rocks of the biotite-almandite subfacies of the epidote-amphibolite facies. Aluminum (A), calcium (C), ferrous iron, magnesium, and manganese combined (F), potassium (K)--all in atomic ratios. The points for muscovite and microcline are on $A K$ edge and the point for biotite on the $A K F$ face of the transparent tetrahedron. The fields of stability for various mineral assemblages are determined by placing planes through points for minerals that can coexist. These planes divide the tetrahedron into pyramidal sections which have a triangular or quadrilateral base and a vertex in the point for epidote. The pyramidal sections are shown separately on the right. The lines on the back face (ACF) of the tetrahedron are broken lines, those going through the tetrahedron are stippled. Each pyramidal field of stability carries the number of the mineral assemblage mentioned in the text that is stable within it. The numbers with a letter $(a, b, c)$ refer to the faces of these pyramidal sections. For instance, the mineral assemblage 3 is stable in all rocks whose composition would fall within the pyramid (3) that has the triangle almandite-biotite-hornblende as base and whose vertex is in the point epidote. The mineral assemblage $3 a$ is stable in all rocks whose composition is on the face : hornblende-almandite-epidote. 


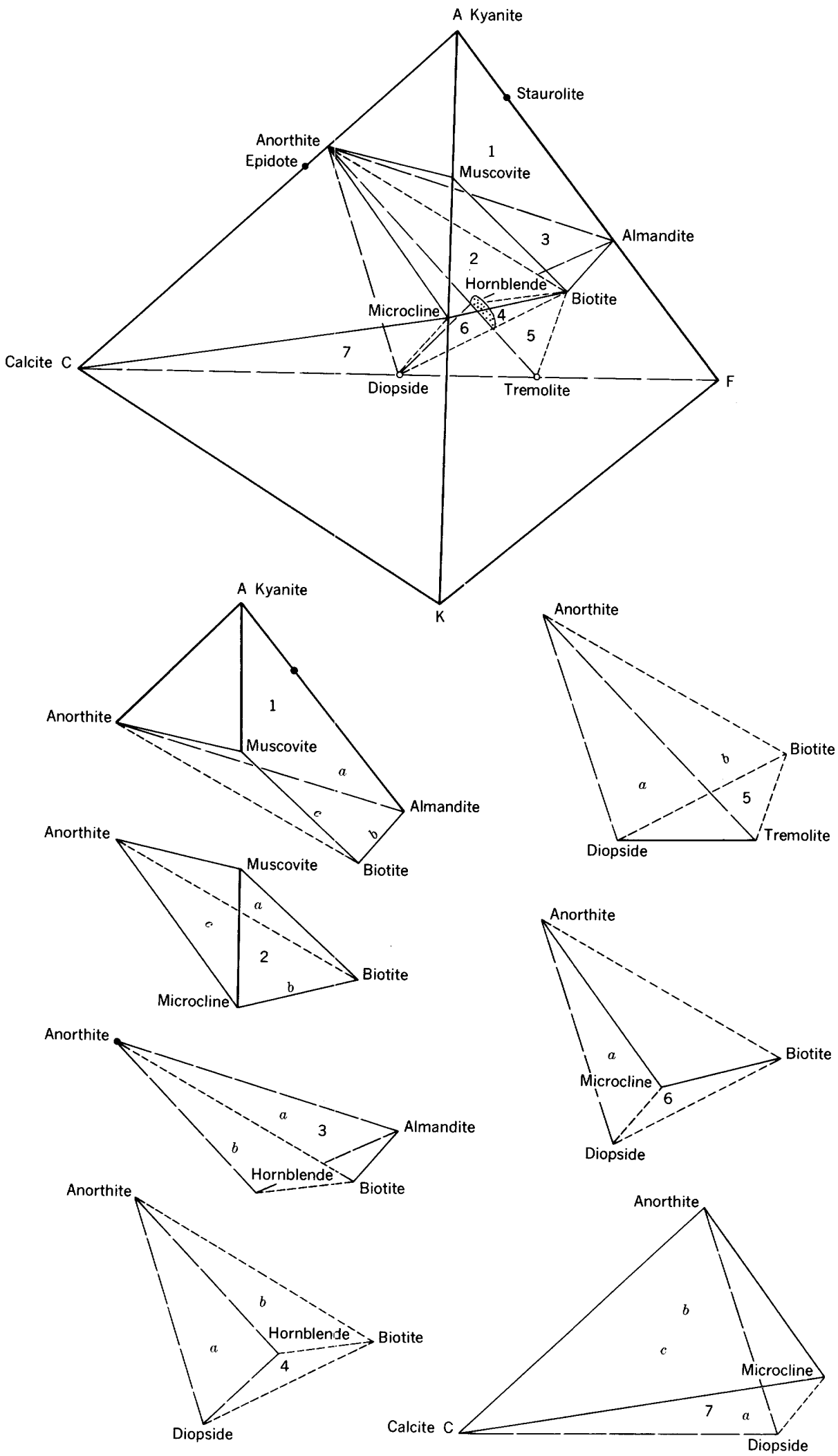

FIGURE 17.-ACFK diagram for the rocks of the staurolite-kyanite subfacies of the epidote-amphibolite facies. Aluminum (A), calcium (C), ferrous iron, magnesium, and manganese combined (F), potassium (K). The fields of stability for the mineral assemblages mentioned in the text (1-7) are constructed in the same way as in figure 16. 


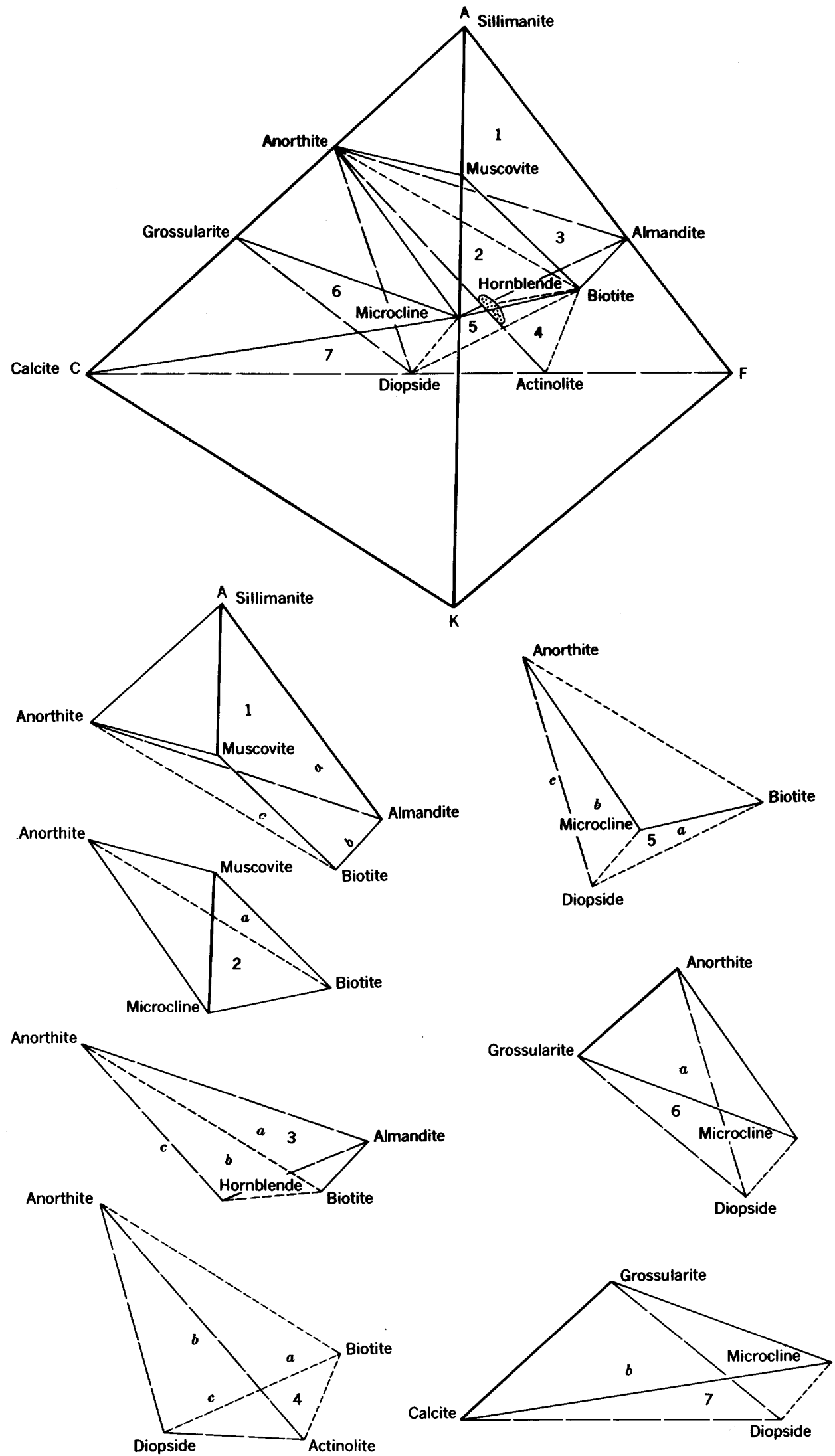

Frgure 18.-ACFK diagram for the rocks of the sillimanite-muscovite subfacies of the amphibolite facies. Aluminum (A), calcium (C), combined ferrous iron, magnesium, and manganese (F), potassium (K). The fields of stability for the mineral assemblages mentioned in the text (1-7) are constructed in the same way as on figure 16. 
If the index minerals of each assemblage are connected by lines, and planes constructed through each three or four points, these planes will intersect along the lines and divide the tetrahedron into pyramidal sections and subtetrahedra. Each of these subtetrahedra will include the bulk compositions of all rocks in which the mineral assemblage defined by the corners of the subtetrahedron is stable. The subtetrahedra and the pyramidal sections are keyed by numbers to the tetrahedron. The numbers with letters $a, b$, and $c$ in the text refer to the triangular and quadrilateral faces of these sections. It is apparent that only a portion of possible mineral assemblages is represented by the thin sections studied. The plots for the bulk compositions of rocks with only three stable index minerals, such as the assemblage biotitemuscovite-epidote-(albite-quartz) would fall on the plane biotite-muscovite-epidote. The plots for the bulk compositions of rocks with only two index minerals will fall along the lines connecting the points for these two minerals.

The principle of this presentation is the same as used by Eskola (1915, 1939) and later by Turner (1948), Barth (1936, 1952), Thompson (1957), Fyfe, Turner and Verhoogen (1958), and many others, and the same theoretical considerations concerning the equilibrium assemblages are valid. The 4-phase assemblages in this tetrahedral projection form from any bulk composition that plots within subtetrahedra determined by the index minerals at the corners. The compositions at the corners respond to variation in $\mathrm{P}, \mathrm{T}$, and $\mu \mathrm{H}_{2} \mathrm{O}$ during the recrystallization, giving different diagrams for various facies and subfacies (compare figs. 16 to $18)$.

The assemblages of more than four minerals are of particular interest. According to the phase rule, the number of minerals cannot exceed that of the components if the assemblage was formed in equilibrium conditions, or then the number of variants $P, T$, $\mu \mathrm{H}_{2} \mathrm{O}$ is reduced to two (bivariant equilibrium) or to one (univariant equilibrium). Such an assemblage would be, for instance, No. 1 on figure 16: andalusitealmandite-biotite-muscovite-epidote-(albite-quartz) the bulk compositions of which would be within a foursided pyramidal section. If the fourth component, calcium, is eliminated, the tetrahedron ACFK would be reduced to the triangle $\mathrm{AKF}$ and in this diagram the assemblage andalusite-muscovite-biotite-almandite has four phases instead of three. Similar cases have been noted by many other authors; Turner and Verhoogen $(1951$, p. 425) consider the common occurrence of the assemblages as a sign that they were formed in equilibrium and suggest that this situation may arise because the components in the graphic presentation are too few. Thompson (1957, p. 856-857) considers that these cases with too many phases include discontinuities in facies, and that these discontinuities represent conditions of either univariant or bivariant equilibrium-the latter when water is gained or lost.

In the Elk River-Clarkia area several assemblages with five phases were noted as shown with the pyramidal sections on figures 16 to 18 . Some of these involve a change either of pressure or of temperature and some probably are combinations of normal trivariant systems. An example of the former type would be the assemblage andalusite-almandite-biotite-muscoviteepidote of the andalusite subfacies (fig. 16 for andalusite) and of the latter type the assemblage hornblendebiotite-microcline-calcite-epidote.

The field of stability for the andalusite-bearing rocks would be the four-sided pyramidal section illustrated on figure 16-1. By joining the opposite corners of the quadrilateral base this section can be divided into subtetrahedra in two ways (dotted lines on fig. 16-1). The assemblages, such as almandite-biotite-muscoviteepidot-(albite-quartz), crystallize in stable equilibrium from the bulk compositions that plot in the subtetrahedron determined by the four critical phases at the corners. In this case no andalusite appears and the almandite corner is joined with the muscovite corner. From some bulk compositions, such as $\mathbf{X}$ on figure 16, the above assemblage as well as the assemblage andalusite-almandite-biotite-epidote-(albitequartz) can crystallize; if no muscovite appears the andalusite corner is joined with the biotite corner. From the bulk compositions that plot along the join between epidote and the intersection of almanditemuscovite and andalusite-biotite joins, all four critical phases at the corners of the quadrilateral base may crystallize with epidote, albite, and quartz. The ratio in the amounts of the two pairs at opposite corners of the quadrilateral base may vary to a certain extent, as determined by substitution of iron by magnesium in almandite and biotite. The reaction involved can be expressed as follows:

\begin{tabular}{|c|c|c|c|}
\hline \multicolumn{4}{|c|}{1 biotite +4 andalusite +2 quartz $\rightleftharpoons$} \\
\hline Sp. gr $\ldots \ldots$ & 3. 15 & 2. 65 & \\
\hline Mol. vol_. $355.42+$ & $4 \times 51.43+$ & $\times 22.66$ & \\
\hline & 606. 46 & & \\
\hline & & 2 almandite +1 & uscovite \\
\hline & & 4. 12 & 2. 90 \\
\hline & & $2 \times 120.79+$ & 274.62 \\
\hline & & 516. 2 & \\
\hline
\end{tabular}

This reaction takes place without gain or loss of water, is thus univariant, and involves a change in the topology of the projection. The right-hand side of 
this equation would have somewhat smaller molecular volume; thus a higher pressure might accelerate the crystallization of garnet and muscovite instead of biotite and andalusite. The pseudomorphs of muscovite after andalusite, west of Cedar Butte, could be a resulti of such a reaction. Alternately, a higher temperature would favor the formation of biotite and andalusite instead of garnet and muscovite. The above equation is valid only if the iron-magnesium ratio in the biotite is the same as that in the almandite. Generally biotite contains more magnesium and the excess of iron crystallizes as magnetite.

To visualize the fields of stability of the hornblende-, biotite-, and microcline-bearing assemblages in three dimensions, the ACFK tetrahedron was constructed from wire and paper. The critical minerals shown on figure 16 were plotted in it and connected with pieces of straight wire. It was apparent that with a slight variation in the aluminum content of hornblende and biotite, the calcite-biotite join can be in the same plane as the hornblende-microcline join, or above or below it. The common occurrence of the mineral assemblages hornblende-biotite-microcline-epidote, hornblende-biotite-microcline-calcite, and hornblende-biotite-calcite-scapolite-all with albite and quartz-in thin adjoining layers indicates that aluminum is distributed between hornblende and biotite in such a manner that the points for hornblende, biotite, microcline, and calcite will fall into the same plane (base of pyramid 4, fig. 16). In some layers these four minerals occur together with scapolite (for example, No. 1917, table $5)$. Theoretically either epidote or tremolite should be stable with these four minerals.

The mineral associations found in the thin sections suggest that, with a slight variation in the composition of the rock, 1 or 2 of the 4 minerals hornblende, biotite, microcline, and calcite can be missing and the rest of the minerals give assemblages which are numbered from 5 to 8 on p. 72. The field of stability for each of these assemblages would be a subtetrahedron within the 4-sided pyramid 4 or any of the faces of the subtetrahedrons and represent normal trivariant systems.

In the schist of the central part of the map area ( $T$. $42 \mathrm{~N}$., across the map) staurolite appears with kyanite. Large prism-shaped groups of small crystals of kyanite and a small amount of staurolite occur on Anthony Peak. In the vicinity of Stony Butte small crystals of kyanite and staurolite occur with large muscovite and biotite flakes. Toward the south the amount of kyanite decreases, staurolite disappears, and sillimanite appears in increasingly large quantities. On Hemlock Butte kyanite is rare, but sillimanite abounds.
None of the thin sections of schist of the Wallace formation in T. $41 \mathrm{~N}$. contain staurolite. Muscovite abounds in some layers, but its total amount definitely decreases toward the south. The common mineral assemblages in the schist in the central part (T. 42 N.) are (fig. 17) :

1. Kyanite-staurolite-almandite-biotite-muscoviteplagioclase-quartz,

1a. kyanite - staurolite-almandite-biotite-muscovitequartz,

1b. almandite-biotite-muscovite-quartz,

1c. almandite-biotite-plagioclase-quartz.

The following mineral assemblages are common in quartzofeldspathic layers:

2. Muscovite - biotite - microcline - plagioclase$\left(\mathrm{An}_{15-20}\right)$-quartz,

2a. muscovite-biotite-plagioclase $\left(\mathrm{An}_{\mathbf{2 0}}\right)$-quartz,

2b. muscovite-biotite-microcline-quartz,

2c. biotite-microcline-plagioclase $\left(\mathrm{An}_{\mathbf{2 0}}\right)$-quartz.

Garnet amphibolite shows the following mineral assemblages:

3. Horneblende - almandite - biotite - plagioclase $\left(A n_{30}\right)$-quartz,

$3 a$. hornblende-almandite-plagioclase $\left(\mathrm{An}_{30}\right)$-quartz, $3 b$. hornblende-biotite-plagioclase $\left(\mathrm{An}_{20-30}\right)$-quartz.

The calcium-rich layers in the quartzite-gneiss units of the Wallace formation in the central part of the area contain abundant diopside, but rarely epidote minerals. Typical mineral assemblages are as follows:

4. Diopside-hornblende-biotite - plagioclase $\left(\mathbf{A n}_{20}\right)$ quartz.

4a: diopside-horneblende-plagioclase $\left(\mathrm{An}_{20}\right)$-quartz,

4b. diopside-biotite-plagioclase $\left(\mathbf{A n}_{\mathbf{2 0}}\right)$-quartz,

5. diopside-tremol ite-biotite-plagioclase $\left(\mathrm{An}_{12-30}\right)$ quartz,

5a. diopside-tremolite-plagioclase $\left(\mathrm{An}_{12-30}\right)$-quartz,

$5 b$. tremolite-biotite-plagioclase $\left(\mathrm{An}_{12-30}\right)$-quartz,

6. diopside - biotite - microline - plagioclase $\left(\mathbf{A n}_{20}\right)$ quartz,

6a. diopside-microcline-plagioclase $\left(\mathrm{An}_{20}\right)$-quartz,

- 7. diopside - calcite - microcline - plagioclase $\left(\mathbf{A n}_{20}\right)$ epidote-quartz,

$7 a$. diopside-calcite-microcline-quartz,

7b. diopside - calcite - plagioclase $\left(\mathrm{An}_{20}\right)$ - epidotequartz,

7c. microcline-calcite-plagioclase-epidote-quartz.

These mineral assemblages are those commonly found in the staurolite-kyanite subfacies of the epidoteamphibolite facies. In the graphic presentation kya- 
nite occurs in the $\mathbf{A}$ corner of the tetrahedron (fig. 17). The point for staurolite $\mathrm{HFe}_{2} \mathrm{Al}_{9} \mathrm{Si}_{4} \mathrm{O}_{24}$ divides the $\mathrm{AF}$ edge in ratio 2:9. Diopside is stable with tremolite and hornblende. Oligoclase instead of albite is common and epidote occurs with it. The mineral assemblages that are stable in the pyramidal sections of the tetrahedron are numbered from 1 to 7 ; those with a letter $a, b, c$ represent mineral assemblages that are stable on the faces of the pyramidal sections.

Light-green hornblende occurs with diopside in some localities, and tremolite coexists with calcite and diopside, suggesting a middle-grade subfacies. The zone in which kyanite occurs with sillimanite is fairly narrow and is considered to represent a transition from the kyanite-almandite subfacies to the sillimanitemuscovite subfacies. Anthophyllite was found only in one locality about a mile west of Freezeout Mountain where it occurs with plagioclase and biotite.

In the southern part of the area (Tps. 39 and $40 \mathrm{~N}$.) only sillimanite, but no kyanite nor staurolite, occurs in the schists, which suggests that the degree of metamorphism there is higher than in the central part. The grain size becomes larger toward the south and in many places pegmatitic veinlets, ranging from 3 to $20 \mathrm{~mm}$ in width, occur in the schist parallel to the bedding. The amount of biotite is larger and muscovite smaller than in the central part. Typical mineral assemblages in the schist are as follows:

1. Sillimanite-almandite-biotite-muscovite-plagioclase $\left(\mathbf{A n}_{\mathbf{2 0 - 3 5}}\right)$-quartz,

1a. sillimanite-almandite-biotite-muscovite-quartz,

1b. almandite - biotite - (muscovite) - plagioclase$\left(\mathrm{An}_{20-35}\right)$-quartz,

2a. biotite-muscovite-plagioclase $\left(\mathrm{An}_{20-35}\right)$-quartz.

Garnet in the amphibolite is mainly almandite with some pyrope. The mineral assemblages are as follows:

3. Hornblende - garnet - biotite - plagioclase $\left(\mathbf{A n}_{36}\right)$ quartz.

3a. hornblende-garnet-plagioclase $\left(\mathrm{An}_{36}\right)$-quartz,

36 . hornblende-garnet-plagioclase $\left(\mathrm{An}_{36}\right)$-quartz,

$3 c$. horneblende-plagioclase $\left(\mathrm{An}_{30-36}\right)$-quartz.

The gneissic layers are somewhat coarser than the corresponding layers in the central part, and in many places the bedding is obscured by intense recrystallization. The most marked change in the mineralogy is the scarcity of potassium feldspar. Typical mineral assemblages are as follows:

4. Diopside-biotite-actinolite-plagioclase $\left(\mathbf{A n}_{30-85}\right)$ quartz,

4a. biotite-actinolite-plagioclase $\left(\mathrm{An}_{35}\right)$-quartz,

4b. diopside-biotite-plagioclase $\left(\mathbf{A n}_{30}\right)$-quartz, 4c. diopsite-actinolite-plagioclase $\left(\mathrm{An}_{12-30}\right)$-quartz,

5. diopside-biotite-microcline-plagioclase $\left(\mathrm{An}_{12-30}\right)$ quartz.

$5 a$. diopside-biotite-microcline-quartz,

$5 b$. diopside-microcline-plagioclase $\left(\mathrm{An}_{12-30}\right)$-quartz,

5c. diopside-plagioclase $\left(\mathrm{An}_{30-85}\right)$-quartz,

$6 a$. diopside-grossularite-plagioclase $\left(\mathrm{An}_{86}\right)$-quartz,

7b. diopside-calcite-grossularite-quartz.

In the graphic presentation sillimanite occurs in the A corner of the tetrahedron (fig. 18). Grossularite is found in some calcium-rich layers, but microcline, though a stable compound in this subfacies, is usually missing. This suggests a compositional limitation of the gneissic layers close to the ACF face. Biotite is common in all other assemblages except in Nos. $5 c$, $6 a$, and $7 b$. Magnesium-rich layers have actinolite instead of tremolite; staurolite is missing. Epidote minerals appear only in hydrothermally altered parts of the rocks next to shear zones and to intrusive bodies. In every subfacies the composition of plagioclase varies to a certain extent according to the amount of calcium present in the original sediment.

Actinolite is present only in a few thin laminae and layer- and lens-shaped bodies in the diopside-plagioclase gneiss; its dark-green color contrasts strongly with the light grayish-green host rock. The mode of occurrence of actinolite indicates that it crystallized in the magnesium-rich portions of the original dolomitic sandstone; its existence reflects the chemical composition of the parent sediment rather than a local lower temperature-pressure field. Diopside crystallized where enough calcium was present, which, together with the mineral assemblages listed above, proves that in the southern part of the area the conditions during the metamorphism were those of the sillimanite-muscovite subfacies of the amphibolite facies.

As described above staurolite is always accompanied by kyanite, whereas staurolite-almandite rocks are well developed in the schist of the Wallace formation about 30 miles east of Clarkia, where they are interbedded with layers that contain kyanite in addition to staurolite and almandite. Only almandine, biotite, and muscovite occur in the specimens from the schist of the Prichard formation north of the kyanite-bearing rock, north of Freezeout Mountain and of White Rock. The lack of staurolite in this schist is probably due to an unsuitable chemical composition rather than to differences in temperature and pressure since staurolite appears again in schists east of Freezeout 
Mountain. Dark prisms which may have been staurolite but are completely altered to sericite, biotite, and magnetite are present in the garnet-biotite-muscovite schist $4 \frac{1}{2}$ miles west of Clarkia, about 1 mile west of the map area.

Staurolite disappears with crystallization of sillimanite, but the stability range of kyanite overlaps that of sillimanite between White Rock and Hemlock Butte. These stability relations are shown on table 9 by arrows extending over the lines separating the fields of various subfacies.

Almandite, biotite, and muscovite are stable over the whole area, but their amount and grain size varies as indicated on table 9. Plagioclase becomes more calcic toward the south. Clinozoisite is the major epidote mineral in the northern part, but zoisite and epidote also occur. In the southern part, epidote is confined to hydrothermally altered portions of the gneisses.

Potassium feldspar appears in notable quantities only in two specimens from the southern part. One of these specimens, No. 1992, table 5, is from a layer interbedded with the white granular quartzite between Weitas and Falls Creeks; the other one (No. 266) is from a layer of migmatized biotite gneiss on the North Fork of the Clearwater River. Microcline occurs in both samples as large grains that include small round quartz grains. The abundance of microcline in the rocks of the epidote-amphibolite facies and its scarcity in the rocks of the amphibolite facies, is contrary to the normal distribution of this mineral in regionally metamorphosed areas. This abnormal distribution may be due either to a lateral variation in the composition of the original sediment or to a later metasomatic rearrangement of elements near intrusive bodies, as will be discussed on page $\mathrm{C} 43$.

\section{STRUCTURE OF THE BELT SERIES}

The structure on a regional scale is discussed in another report (Hietanen, 1961a). Attention here is called only to some local features.

\section{BEDDING}

In most rocks the bedding is distinct because of sharp differences in the mineral content of adjacent layers. This structural element is especially striking in the thin-bedded gneisses (fig. 3) where darkgray biotite-bearing layers alternate with either light-green diopside-bearing or light-gray to white plagioclase-bearing layers. In the quartzites the variation in the amount of micaceous minerals and feldspars makes the bedding recognizable, but it is not nearly as striking as it is in the gneisses. The thickness of individual beds in the gneisses and quartzites has been given in connection with the stratigraphic and petrographic descriptions.

In the schists, the bedding is not as pronounced as in the gneisses; it is however, recognizable in most outcrops. The thickness of the individual beds ranges from a few centimeters to a meter; thicknesses between 10 and $30 \mathrm{~cm}$ are most common. Bedding is distinct in the localities where layers of biotite gneiss or quartzite are interbedded with the schist. The thickness of these beds is, as a rule, less than that of the micaceous layers, and ranges from 1 to $10 \mathrm{~cm}$. However, thicker layers consisting of laminated biotite gneiss are interbedded with the schist. The laminae in these layers consist of large muscovite flakes.

\section{FOLDING, AXIS OF FOLDING, AND LINEATION}

In the northern part of the area the rocks of the Belt series are generally gently folded; the amplitudes of the folds are smaller than their wave length of 1 to 2 miles. Some folds, however, are strongly overturned, especially near fault zones. The flanks of folds are usually straight, as shown in the topography by many dip slopes east of Clarkia, and the crests are rather sharply bent. Toward the south the folding becomes more intense, and along the North Fork of the Clearwater River steeply dipping flanks of isoclinal folds are exposed. In the eastern part of the area the axes of most large folds plunge to southeast, and in the western part to the west-northwest; but there are many local deviations.

In addition to large folds there are folds of outcrop size or smaller, the axes of which coincide with the direction of lineation as discussed below. The small folds are more common in the southern part, and some migmatized parts of the strata are intricately folded. Migmatitic veins, formed by segregation of quartzofeldspathic material, parallel the bedding.

Lineation is well developed in schist and in micaceous layers in gneiss and quartzite. It is a minor wrinkling of bedding surfaces around an axis which makes an angle from $45^{\circ}$ to $90^{\circ}$ with the axes of major folds. In many localities tight folds of considerable size were developed around the axis of wrinkling, and these folds were folded a second time around the major axis.

An example of this type of folding is well exposed in an area 3 miles southeast of Elk River, where the axes of small overturned folds plunge $10^{\circ} \mathrm{SW}$. (fig. $19)$, and the axes of large gentle folds are horizontal, striking eastward. The folding on this east-west axis is later, and a still later movement on the axis that plunges $10^{\circ}$ southeasterly caused a doming of previously folded strata. Large folds on axes that strike 
TABLE 9.-Stability ranges of critical minerals in schists and calcareous gneisses, northwest of the Idaho batholith

\begin{tabular}{|c|c|c|c|c|c|c|c|c|c|c|c|c|}
\hline \multirow{2}{*}{ 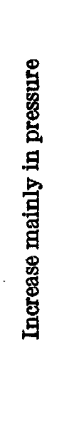 } & $\begin{array}{l}\text { Biotite-almandite subfacies } \\
\text { of the epidote-amphibolite } \\
\text { facies in T. } 43 \mathrm{~N} \text {., R. } 1 \text { to } \\
3 \mathrm{E} \text {. }\left(T=380^{\circ} \text { to } 400^{\circ} \mathrm{C}, P\right. \\
\text { about } 5,000 \text { bars }) .\end{array}$ & (Andalusite) & Alma & ndite & Muscovite & Biotite & Quartz & $\begin{array}{l}\text { Light-green } \\
\text { hornblende }\end{array}$ & Tremolite & Clinozoisite & \multicolumn{2}{|c|}{ Plagioclase Microcline } \\
\hline & $\begin{array}{l}\text { Staurolite-kyanite subfacies } \\
\text { of the epidote amphibolite } \\
\text { facies in T. } 42 \mathrm{~N} \text {., } \mathrm{R} .1 \text { to } \\
3 \mathrm{E} \text {. }\left(T=400^{\circ} \text { to } 470^{\circ} \mathrm{C}, P\right. \\
\text { about } 5,500 \text { bars }) .\end{array}$ & Kyanite, staurolite & 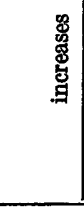 & 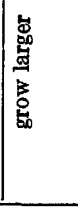 & 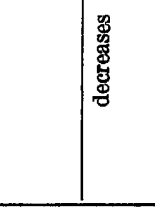 & 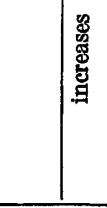 & 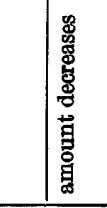 & Diopside & & & $A n_{10-20}$ & \\
\hline 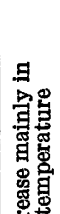 & $\begin{array}{l}\text { Sillimanite-muscovite sub- } \\
\text { facies of the amphibolite } \\
\text { facies in T. } 39 \text { to } 40 \text { N., } \\
\mathrm{R} .1 \text { to } 3 \mathrm{E} .\left(T=470^{\circ} \text { to }\right. \\
580^{\circ} \mathrm{C}, P \text { about } 5,500 \text { bars). }\end{array}$ & Sillimanit & & & & & & 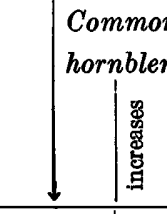 & de & $\mid$ & 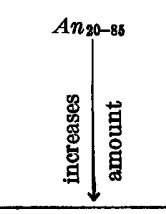 & \\
\hline 皃 & Quartz diorite melting point. & & & & & 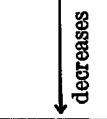 & & & . & & $A n_{35-38}$ & \\
\hline
\end{tabular}




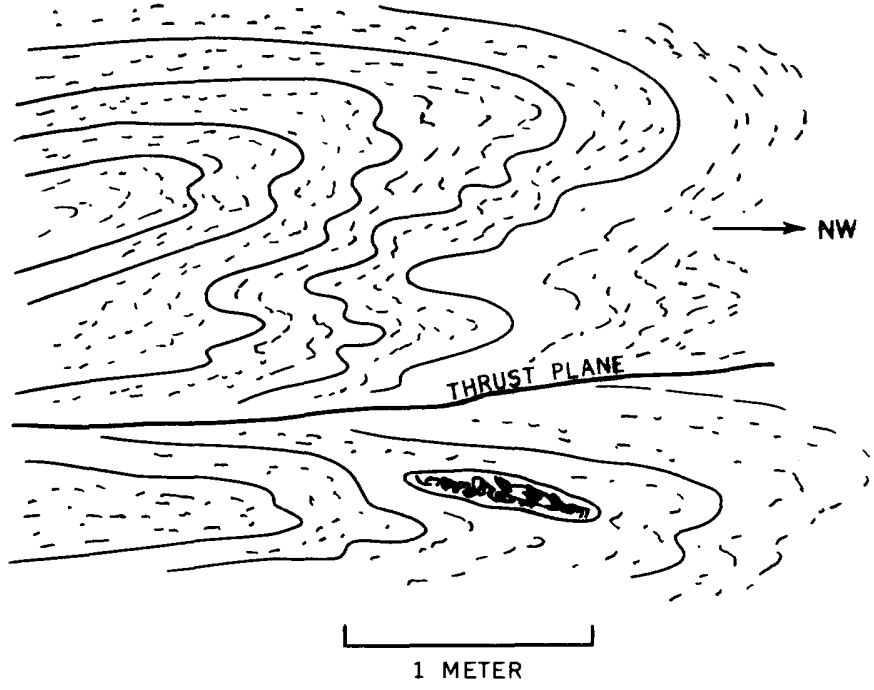

Figure 19.- Small folds overturned to the northwest in thin-bedded biotite-diopside-plagioclase gneiss just east of logging camp 43,3 miles southeast of Elk River, a vertical road cut facing to northeast. Thrust plane dips gently to the southeast.

in the same direction as the lineation in nearby outcrops are seen 2 miles southeast of Anthony Peak in the north-central part of the area, around the mouth of Glover Creek, and just south of Breakfast Creek along the eastern edge of the map area.

In schist of the Prichard formation in the northeastern part of the area, lineation plunges either $15^{\circ} \mathrm{W}$. or $20^{\circ}$ E. because of gentle folding around the axis that plunges $10^{\circ}$ S.E. (see for instance pl. 1, sec. 23, T. 43 N., R. 3 E.). Folds around the lineation are common, but here it is not clear whether they are earlier or later than the major folding on the southeasterly axis.

In most outcrops the direction of lineation deviates $50^{\circ}$ to $85^{\circ}$ from the direction of the fold axis. This relation, together with the development of fairly large folds around the lineation, suggests that the lineation represents an independent structural element, a second folding, which in some localities (fig. 19) is earlier and in some others later than the major folding.

The general direction of the major fold axes coincides with the regional trends of the south end of an arcuate segment of Nevadan folding that strikes southward in British Columbia and southeast north of the Idaho batholith (Eardley, 1951). The wrinkling and second folding around the northeast- or southwestplunging axes is analogous to a similar structure south of the Elk River-Clarkia area (Hietanen, 1962). This structure parallels the regional trend of the north end of an arcuate segment of Nevadan folding that strikes north in the Klamath Mountains in California, northeast across Oregon and joins the northern segment just north of the Idaho batholith. The area under in- vestigation lies within the junction of these two arcuate segments. Both segments were formed over the same period of time, but in any locality within the junction the folds on the axis of the northern arc may have been formed either earlier or later than those on the axis of the southern arc.

Small folds on both sets of axes are locally overturned, those on the westerly set to the north (fig. 20) and those on the southeasterly set to the southwest.

A structure resembling overturning but occurring only in certain beds of diopside gneiss is interpreted to be due to sliding of the original sediments under water before their consolidation (fig. $7 B$ ) because the beds just above and below the disturbed strata are not folded synchronously.

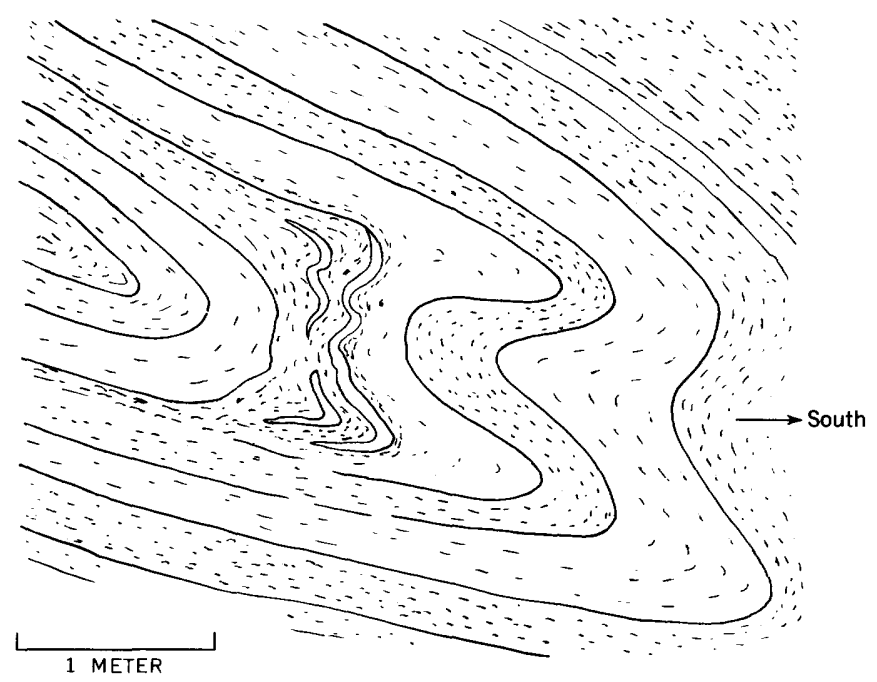

Frgorw 20.-A small syncline in a fine-grained gneissic layer in the schist of the Prichard fcrmation along West Stony Creek at the mouth of Glover Creek. Road cut faces to the west. Overturning is to the north; the axial plane dips gently to the south.

\section{FOLIATION}

Foliation is well developed in all micaceous layers but is not discernible in layers consisting of diopsideplagioclase gneiss and quartzite. The direction of foliation and its relation to the bedding varies. Where the, folding is gentle and the bedding is strongly developed as, for instance, in most of the thin-bedded biotite and diopside gneiss, the foliation is parallel to bedding. A transecting cleavage is developed in strongly folded parts of the strata and near many fault zones. It is pronounced in micaceous layers of the gneisses and in fine- to medium-grained layers of the schist, especially along the crests of folds. In general the transecting cleavage is more common in the northern and in the central part of the area than in the southernmost part, where the folding is more intense. This seems contradictory, but can be explained 
to be due to a different type of folding and to the difference in the plasticity of the material folded. On the flanks of the isoclinal folds along the North Fork of the Clearwater River, the foliation either parallels the bedding or deviates only $5^{\circ}$ to $20^{\circ}$ from it. In the intricately folded migmatized parts of the schist and gneiss there, the foliation as well as the quartzofeldspathic veins parallel the bedding. Segregation of the quartzofeldspathic material accentuated the bedding and encouraged bedding-plane slippage during folding.

\section{FAULTS}

A major north-trending zone of near vertical faults extends across the north-central part of the area and turns to a northwesterly trend in the central and eastcentral part. Movement along this fault zone has raised the rocks of the Prichard formation on the northeast with respect to those of the Revett, St. Regis, and Wallace formations on the west and southwest; the maximum displacement is about $400 \mathrm{~m}$. The fault zone consists of a number of smaller faults, some of which are steep normal, the others vertical; most of them strike northerly but are connected by others that strike northwesterly. Together they form a zone that parallels the major structural trend.

Local faults and dikes parallel to this same direction occur in the central part of the area near Elk River and northwest of Clarkia. The other faults in the area strike either $5^{\circ} \mathrm{N}$. to $10^{\circ} \mathrm{E}$., or east to eastnortheast. These faults have displaced various layers of the Wallace formation, and the vertical movement along them is far less than that along the major fault zone. The east-northeast-striking faults are perpendicular to the major structural trend, which forms an arch in the central part of the area. These faults are thus transverse faults formed perpendicular to the major direction of tension.

Small faults are very common in and next to the Revett quartzite. Some of these faults are parallel to the major fault directions, but others exhibit a rather irregular breakage. Most of them dip almost vertically (see plate 1 , cross section $A-A^{\prime}$ ).

A small overthrust fault cuts diopside-biotite gneiss of the Wallace formation northwest of Elk River (fig. 21). Thrusting at right angles to the bedding has brought thin-bedded biotite-diopside gneiss on top of thick-bedded diopside gneiss.

\section{PLUTONIC ROCKS}

Two large and several small intrusive bodies invade the rocks of the Belt series. The two larger bodies are stocks of quartz diorite and quartz monzonite; the small bodies are granite, quartz diorite, tonalite, or various gabbroic rocks. At least part of the amphibolite is igneous, but some small bodies may be metamorphic and metasomatic. Because it is impossible to distinguish the various types with adequate certainty, all amphibolite is discussed under the same heading.

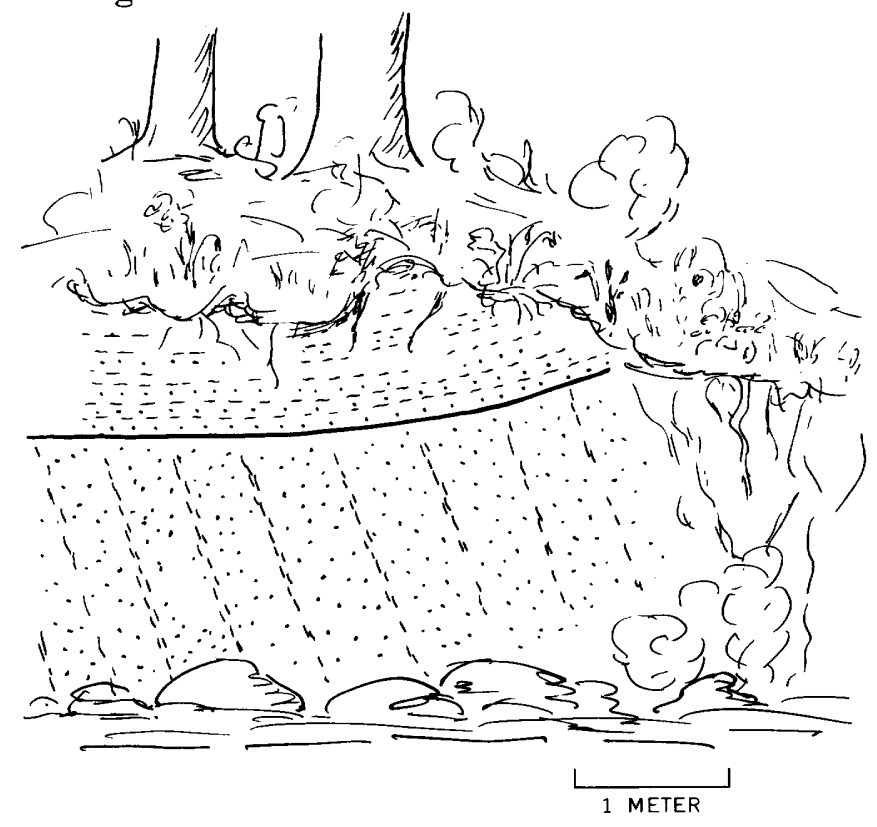

Froure 21.-A small overthrust to the south in diopside gneiss of the Wallace formation along the head of Shattuck Creek, 2 miles east of Jackson Mountain. Road cut faces to the west.

\section{HORNBLENDE GABBRO, AMPHIBOLITE, AND GARNET AMPHIBOLITE}

Only a few small bodies of hornblende gabbro were found in the area. One of them occurs in the quartzite of the Wallace formation in the northernmost part; another body is exposed between the diopside quartzite of the Wallace formation and the underlying schist 2 miles southeast of Green Mountain; and a third tiny body is about 11/4 miles southeast of Gold Butte. The gabbro is coarse to medium grained, massive or slightly gneissic and consists of plagioclase, hornblende, and some quartz. Biotite, sphene, and apatite are additional constituents.

Small sill-like bodies of coarse- to medium-grained well-foliated amphibolite are common in the northeastern part of the area and occur sparsely elsewhere. Most of these bodies are included in the Prichard formation or occur along the major fault zone between the Prichard and the Wallace formations. Most of the amphibolites are fine-grained intrusive gabbroic rocks which became schistose during deformations; some of the small bodies may represent dolomitic lenses in the sandy layers of the schist, and some others, especially those containing abundant garnet; were probably 
formed by metasomatic addition of iron and magnesium to garnet-mica schist. No amphibolite seems to have been derived from tuff. The distinction between the amphibolites of various origins is not clear because there seems to be a complete gradation from one group to another. It is assumed, however, that all dikelike bodies of amphibolite belong to the igneous group. Many of these bodies occur along fault zones, are strongly foliated, and rarely contain garnet. The major constituents are hornblende and plagioclase. Quartz is a common minor constituent; biotite is rare. Contacts between schist and amphibolite of intrusive origin are usually fairly sharp, but some amphibolites grade through gneissic gabbro to gneissic diorite (for example, at Gold Creek).

Some of the garnetiferous amphibolites contain abundant quartz, biotite, and garnet, and through a decrease in the content of hornblende and plagioclase grade into garnet-mica schist. Some coarse-grained amphibolites have large garnets ( 3 to $10 \mathrm{~cm}$ in diameter) enveloped by hornblende or anthophyllite and biotite. The exceptionally large grain size, high content of aluminum-bearing minerals and quartz, and the gradational contacts suggest that these amphibolites may have been formed by introduction of iron, magnesium, and calcium into garnet-mica schist. This type of amphibolite is common along the eastern border of the mapped area and is comparable in its mineralogy and texture to similar rocks in the Boehls Butte quadrangle (Hietanen, 1963).

\section{QUARTZ DIORITE}

A stock of quartz diorite 6 to 8 miles north of Elk River (south of Hemlock Butte) has a surface area of about 7 square miles. Two small masses of similar quartz diorite occur 0.3 to 1.7 miles west of the main body. The stock is poorly exposed, but on the basis of the distribution of residual boulders it is elongate parallel to the major structural trend. In the few outcrops there are no linear or planar structures other than joints. Most of the mineral grains are oriented at random even at the contacts.

A discordant intrusive contact between the quartz diorite and diopside gneiss is exposed at the northwest end of the stock. The quartz diorite cuts sharply across the beds of the diopside gneiss and includes fragments of the gneiss (fig. 22). Large quantities of contact minerals such as epidote occur in the gneiss next to the contact. The quartz diorite next to the contact is coarse to medium grained.

The quartz diorite is petrographically similar to the same rock type in the Headquarters quadrangle (Hietanen, 1962). The major constituents-plagioclase, quartz, hornblende, and biotite-are easily seen. The grain size ranges from 1 to $5 \mathrm{~mm}$. The dark constituents tend to occur in small clusters which give a black and white spotted appearance to the rock.

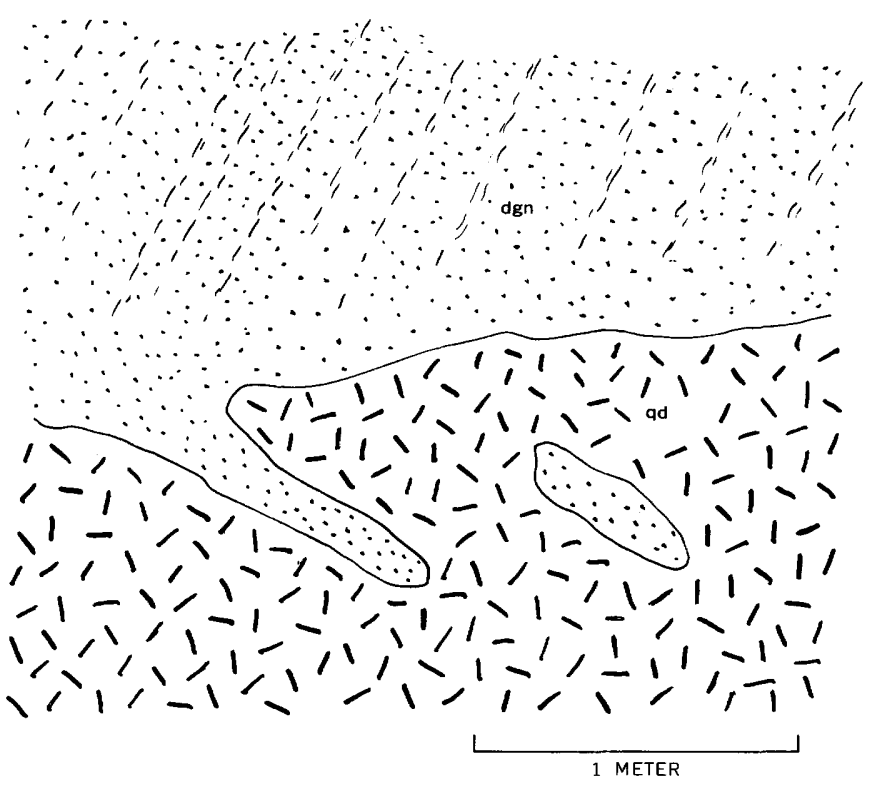

FIGURE 22.-A contact of quartz diorite and the diopside gneiss of the Wallace formation, along a small road on the west side of Elk Creek, $3 \frac{1 / 2}{2}$ miles north of Elk River. Diopside gneiss (dgn). Quartz diorite (qd).

In addition to the major constituents, the rock has small amounts of sphene, epidote, magnetite, pyrite, apatite, zircon, and chlorite. Plagioclase crystals are anhedral (fig. 23A) and show albite, Carlsbad, and complex twinnings. Biotite is partly altered to chlorite with tiny inclusions of rutile. Epidote occurs as irregular-shaped grains next to hornblende and biotite. The crystals of sphene are subhedral and range from 0.01 to $1 \mathrm{~mm}$ in diameter. Tiny apatite prisms have rounded corners.

A small mass of quartz diorite 1.5 miles southeast of Grandmother Mountain and another mass at Gold Center Creek are gneissic. Some potassium feldspar and myrmekite occur with quartz and plagioclase in this rock. Small grains of epidote, apatite, and sphene occur in clusters of hornblende and biotite. The gneissic quartz diorite grades locally to an orthoclasebearing, more silicic variety (fig. 23-B) in which the dark constituents are hornblende and biotite or biotite alone.

\section{QUARTZ MONZONITE}

A stock of quartz monzonite, about 11 square miles in area, is exposed just north of Elk River. It is elongate parallel to the regional trend and seems to butt 


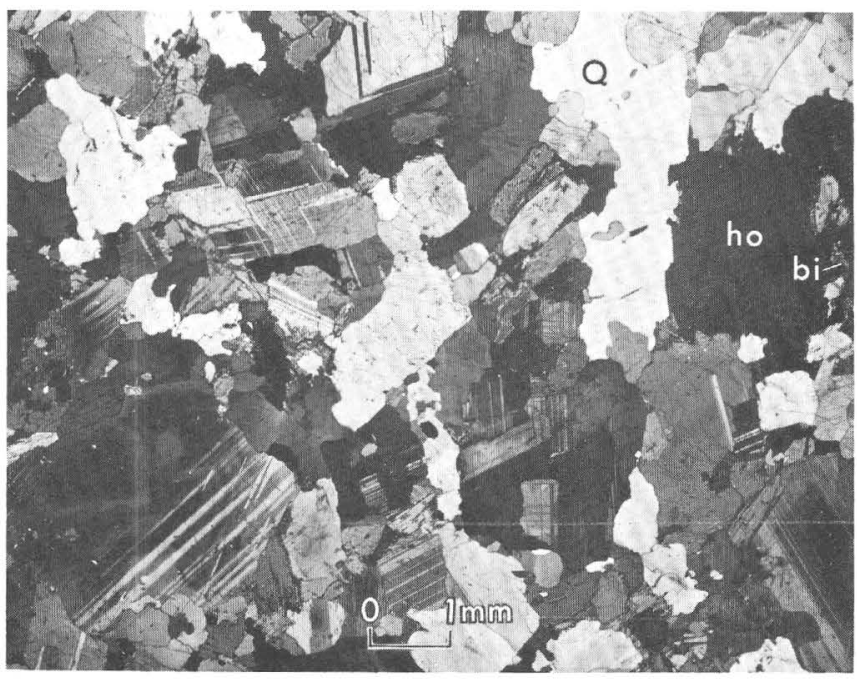

A. Quartz diorite, 1.7 miles south of Hemlock Butte (loc. 1428). Plagioclase is anhedral to subhedral and shows albite, Carlsbad, and complex twinnings. Quartz (Q), hornblende (ho), and biotite (bi) are the other major constituents. Crossed nicols.

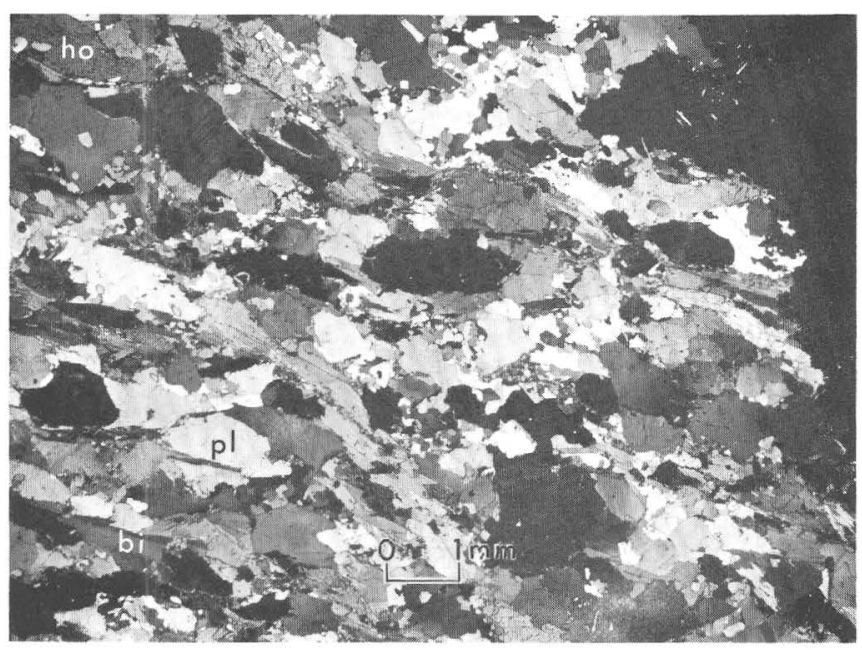

B. Granodioritic gneiss along Gold Center Creek at the mouth of Placer Creek (loc. 1678). Plagioclase $\left(\mathrm{An}_{20}\right)$ is the major light-colored constituent (pla); quartz and orthoclase occur as small grains between the large plagioclase grains. Hornblende (ho) and biotite (bi) are the dark minerals. Crossed.nicols.

FIGURE 23.-PHOTOMICROGRAPHS OF QUARTZ DIORITE AND GRANODIORITE GNEISS.

against faults and porphyritic dikes on either end, but this is uncertain because neither end is exposed. Good outcrops occur along a small road leading from Elk Creek westward to the East Fork of Potlatch Creek and along another road going from Elk Creek about a mile eastward, toward Elk Butte. The rock in these outcrops is coarse grained and light gray, and has a distinct joint system (see pl. 1, 4 miles north of Elk River). In some outcrops the dark minerals are slightly oriented, but in the major part of the stock the minerals are unoriented. The dark constituents occur as small evenly distributed crystals.
This rock has a texture and mineralogy typical of quartz monzonite (fig. 24A). Large anhedral orthoclase

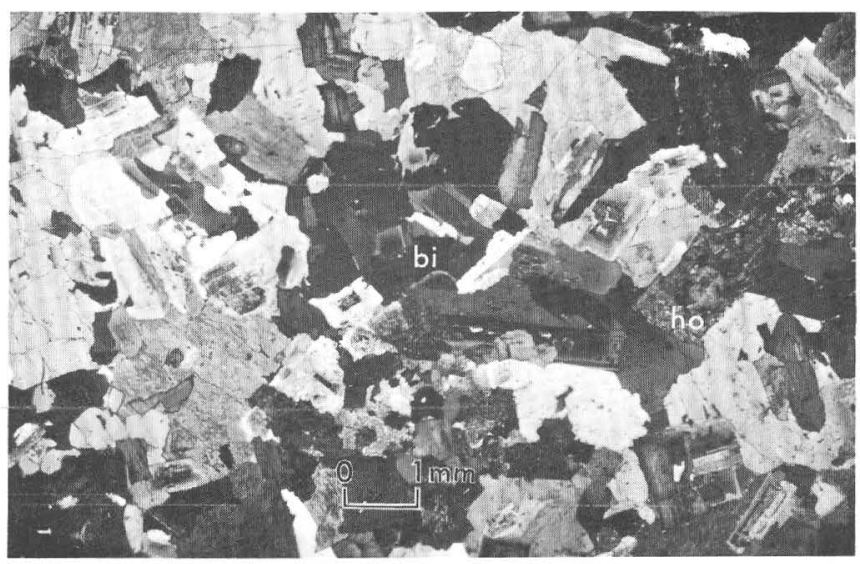

A. Quartz monzonite from the west side of Elk Creek, $41 \frac{1}{2}$ miles north of Elk River. Euhedral plagioclase crystals of medium size are included in large anhedral orthoclase and quartz grains. The dark constituents are hornblende (ho) and biotite (bi). Crossed nicols.

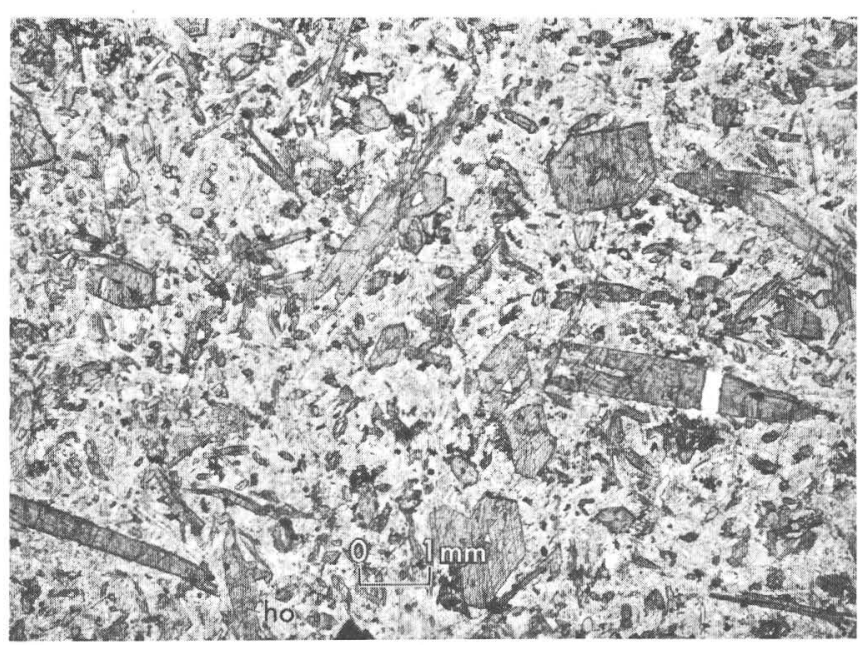

B. Porphyritic hornblende gabbro (lamprophyre) dike along Merry Creek, 2 miles northeast of Clarkia (loc. 1628). Euhedral hornblende (ho) prisms occur as phenocrysts and the groundmass consists mainly of plagioclase and quartz. Plane polarized light.

FIGURE 24.-PHOTOMICROGRAPHS OF QUARTZ MONZONITE AND PORPHYRITIC HORNBLENDE GABBRO.

grains include many small subhedral to euhedral strongly zoned and twinned plagioclase $\left(\mathrm{An}_{25-40}\right)$ crystals. Orthoclase is perthitic and many grains include numerous tiny sericite flakes as an alteration product. The stocky plagioclase laths outside the orthoclase grains are larger than those included in the orthoclase, and their composition ranges from $\mathrm{An}_{40}$ to $\mathrm{An}_{28}$ from the centers of the crystals to their borders. Many small subhedral quartz grains are included in the orthoclase; one the other hand, large quartz grains include plagioclase. Hornblende and biotite fill the interstices between the stocky plagioclase laths that 
are not included in the orthoclase, but some subhedral grains are included in the orthoclase and quartz. Biotite is strongly pleochroic $-\mathrm{Z}=$ dark brown and $\mathbf{X}=$ light brown - and it is partly altered to light-green chlorite. Sphene, epidote, magnetite, and zircon occur as accessories.

A contact between the quartz monzonite and the biotite gneiss of the Wallace formation is exposed along an old logging road on the west side of Elk Creek about 3 miles north of Elk River. The biotite gneiss is brecciated and, instead of biotite, sericite and hematite occur as additional constituents next to the contact. A little farther south pegmatite and granite appear along the contact between the quartz monzonite and sillimanite-biotite-muscovite schist (fig. $25 A$ ). The granite cuts the schist discordantly and sends veins into the schist parallel to its foliation. Because of the lack of exposures it could not be ascertained whether the granite in figure $25 \mathrm{~A}$ is a marginal phase of quartz monzonite or a separate intrusion.

A very light pinkish-gray granite occurs as a marginal facies between the quartz monzonite and the schist along the contact exposed about a mile northnorthwest of Elk River (fig. 25B).
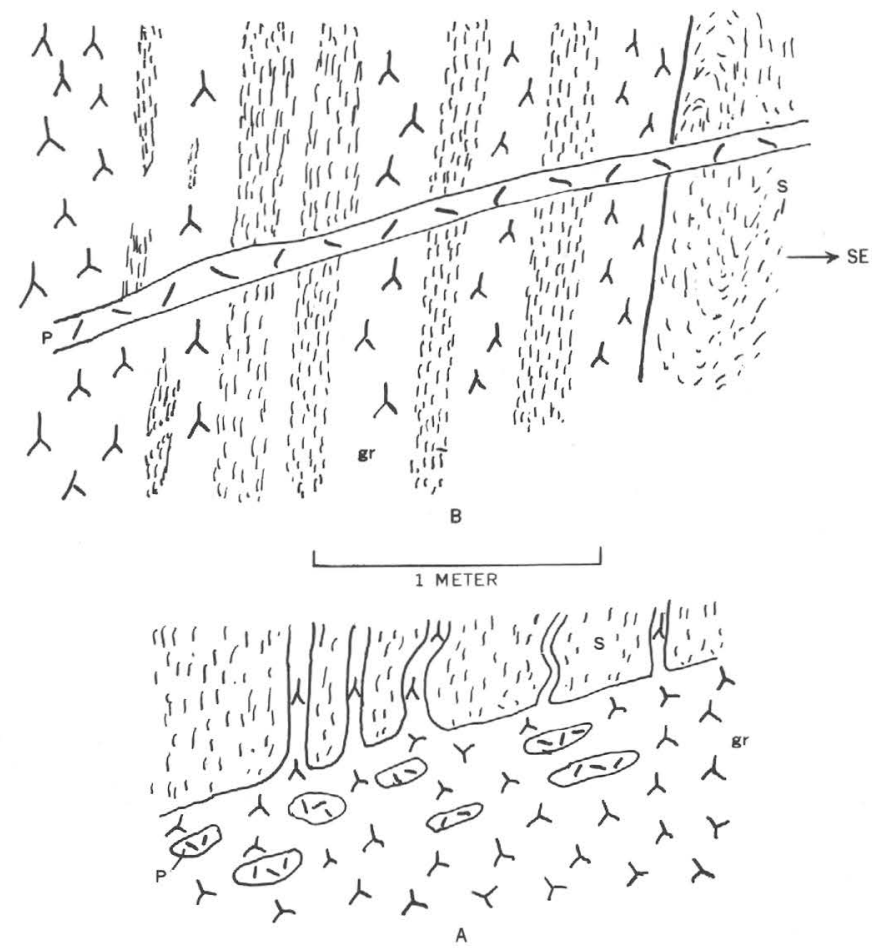

FIgURe 25.-A, A contact zone between schists (S) and a granite (gr) just outside of the large quartz monzonite stock. Granite includes pegmatitic portions ( $P$ ). Along a small dirt road on the west side of Elk Creek about 3 miles north of Elk River. B, A contact between schist (S) and granite (gr) along a logging road a mile north-northwest of Elk River. This granite is a marginal facies of quartz monzonite. Pegmatite $(P)$ cuts the schist and the granitic veins discordantly and is thus the youngest rock type.

\section{GRANITE AND TONALITE}

Several rather small masses of granite, all strongly elongate parallel to the regional trend of the metasedimentary rocks, are shown on the geologic map (pl. 1). Two types of granites, pink and light gray, have been distinguished. Both types are equigranular, coarse to medium grained, and locally gneissic. Gradation from quartz diorite to light-gray granite is common in the northeastern part of the area and locally along the southern margin of the largest quartz diorite stock.

The pink granite has a texture similar to that of the quartz monzonite; euhedral to subhedral, zoned and twinned plagioclase $\left(\mathrm{An}_{17-19}\right)$ crystals are included in quartz and orthoclase. The amounts of quartz and plagioclase each range from 30 to 40 percent and that of orthoclase from 15 to 30 percent. Biotite, partly altered to chlorite, is the only dark constituent, and its amount is 2 to 4 percent. Muscovite and epidote are the common minor constituents. Some of the feldspar grains contain tiny sericite inclusions, and biotite that is slightly altered to chlorite contains rutile needles.

In the light-gray granite the constituent minerals are the same as in the pink variety, but the texture is different. The plagioclase is subhedral. Myrmekite, which occurs in round grains next to the potassium feldspar, is common. Biotite and muscovite flakes show locally a crude parallel orientation.

The sill-like bodies of granite in the Prichard formation in the northeastern part of the area are more gneissic than those in the Wallace formation. There is every gradation from the gneissic quartz diorite to tonalite and to a gneissic granite in which the amount of potassium feldspar is much less than in the normal granite (about 5 percent). The tonalite is more silicic than the quartz diorite, its plagioclase $\left(\mathrm{An}_{20-26}\right)$ is more sodic and it lacks hornblende.

The tonalite in the two small bodies exposed along the eastern border of plate 1 resembles megascopically the gneissic granite and tonalite in the northeastern part. The amount of potassium feldspar in these bodies is 1 to 5 percent, and plagioclase $\left(\mathrm{An}_{20-26}\right)$ constitutes about 50 percent of the rock. The amount of quartz (about 35 percent) is larger than that in the quartz diorite, and biotite is the only dark constituent.

No direct evidence of the age relations between the pink and gray granite was found. If these rocks are correctly correlated with corresponding varieties in the Boehls Butte quadrangle, the pink granite is younger and is a differentiation product of the quartz monzonitic magma. The gradation of the quartz diorite to tonalite and gray granite indicates a common origin for these rocks. Thus, the same twofold division into potassium-rich and potassium-poor series 
that exists along the border zone of the Idaho batholith (Hietanen 1962) is carried over to these satellitic intrusions.

\section{PEGMATITES}

Two types of pegmatites occur in the area, older veins and dikes poor in potassium and younger ones rich in potassium feldspar and in muscovite. The older pegmatitic veins and dikes are cut discordantly by pink granite (fig. 26). On the other hand, younger

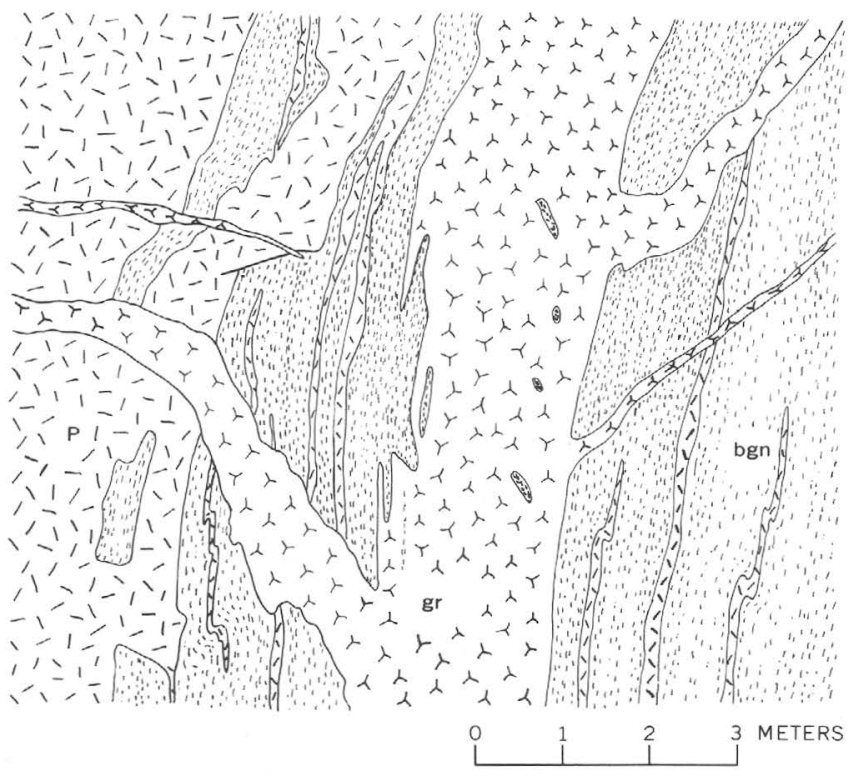

FIGURE 26.-Velns of medium-grained pinkish-gray granite $(g r)$ and older pegmatite $(P)$ in fine-grained biotite gneiss (bgn) of the Wallace formation along Elk Creek, $5 \frac{1}{2}$ miles north of Elk River.

pegmatites cut pink granite that occurs as separate small masses and as a marginal facies (fig. 25B).

The major constituents of the older pegmatites are quartz and plagioclase. Orthoclase, biotite, and muscovite occur in minor quantities.

The younger potassium-rich pegmatites occuras fairly thick dikes, are very coarse grained, and contain-in addition to quartz, orthoclase, and sodic plagioclase-muscovite plates as much as $5 \mathrm{~cm}$ in diameter. Some of the muscovite may be of commercial quality (Stoll, 1950, p. 14).

\section{HYPABYSSAL ROCKS}

Most dikes and sills occur along fault zones in the rocks of the Belt series and follow their major structural trends. The composition of the dike rocks ranges from diabase, pyroxene gabbro, and hornblende gabbro through tonalite to porphyritic granite. Only a few dikes are sheared, showing that they were emplaced before the faulting; most are post faulting and later than the intrusion of Cretaceous quartz monzonite.
DIABASE

Two long dikes of dark fine-grained diabase occur in the northwest corner of the mapped areas. These dikes resemble the nearby Columbia River basalt except that their grains are larger and they have no glass. The long lath-shaped plagioclase $\left(\mathrm{An}_{48}\right)$ crystals show albite, Carlsbad, and complex twinnings and a weak zoning. The pyroxene is greenish-gray augite in groups of subhedral grains. Quartz and granophyric intergrowth of quartz and feldspar fill the interstices between plagioclase laths. Irregular shaped grains of magnetite rimmed by bluish-green hornblende and some grains of green hornblende occur with the augite. Small prisms of apatite and a few scales of ilmenite are the accessories.

A very strongly brecciated diabase dike is exposed in a rock quarry about half a mile northeast of Clarkia on the north side of the St. Maries River. This locality is along the structural continuation of the dikes described above. The diabase breaks along the fracture surfaces that are covered by dark shiny serpentine minerals and white calcite. Included in this diabase are several lens-shaped pockets, layers, and stringers of medium-grained very light gray rock in which the constituent minerals are albite, quartz, calcite, epidote, and some biotite. Between these leucocratic portions and the dark diabase is a layer of medium-grained diabase, a few centimeters thick, in which the amount of light-colored constituents is larger than in the normal diabase. It is clear that the leucocratic portions represent segregations of salic material.

The diabase is very similar to that in the northwest corner, except that the augite crystals include a few grains of orthorhombic pyroxene with low interference colors and are surrounded by blue-green hornblende. Irregular fractures in the othorhombic pyroxene are filled with green alteration products, probably serpentine minerals.

Albite $\left(\mathrm{An}_{5}\right)$, the major constituent (about 70 percent) in the leucocratic portions, occurs in irregularshaped or elongate grains, most of which show twinning. In some grains the twinning lamellae are discontinuous and the grains look checkered under crossed nicols. Calcite fills the interstices between the albite and quartz grains and also traverses the rock in thin stringers. Only a few grains of hornblende occur with biotite. Apatite, sphene, magnetite, and zircon are the accessories.

\section{PYROXENE GABBRO}

A sill-like body, $10 \mathrm{~m}$ thick and consisting of pyroxene-bearing gabbro, occurs along the East Fork of Potlatch Creek 1.5 miles east of the mouth of Mallory 
Creek. This gabbro is dark gray and coarse grained; the white lath-shaped plagioclase crystals are unoriented and contrast strongly with the mesh of dark constituents.

Subhedral augite, brown hornblende, and alteration products - chlorite and epidote-fill most of the interstices between the plagioclase laths. A few of the interstices are filled by quartz. Ilmenite, magnetite, apatite, and allanite occur as minor constituents.

The plagioclase crystals range from 3 to $6 \mathrm{~mm}$ in length, are strongly zoned, and show complex twinnings. Many are filled by alteration products-epidote, sericite, and chlorite - to the extent that the twinning is obscured. Augite occurs next to brown hornblende or is surrounded by hornblende and chlorite. Some of the brown hornblende and augite are altered to bluish-green hornblende, but a greater part, about half, is altered to aggregates of chlorite and epidote. Small elongate grains of epidote and leucoxene are included in the chlorite and contain the calcium and titanium that were originally in augite and hornblende. Allanite occurs in rounded light-brown pleochroic zoned grains. Leucoxene containing magnetite lamellae, and euhedral to subhedral crystals of magnetite occur with the dark constituents. The leucoxene is an alteration product of ilmenite, which has lamellar intergrowths with magnetite. Small prisms of apatite are sparsely scattered throughout the rock.

A sill of similar pyroxene gabbro is exposed along the East Fork of Potlatch Creek, about 1.7 miles west of the area mapped (pl. 1). In this gabbro, granophyric intergrowth of quartz and feldspars fill some of the interstices.

\section{PORPHYRITIC HORNBLENDE GABBRO}

Medium-gray medium-grained dikes of porphyritic hornblende gabbro are common in the north-central part of the area. These dikes traverse the metamorphic rocks parallel to the major fault directions and are more common across the major structural trend than parallel to it.

The hornblende prisms are euhedral (fig. $24 B$ and strongly pleochroic, with $Z=$ brown and green spotted, $\mathrm{Y}=$ green, $\mathrm{X}=$ straw color. The centers of many prisms are chlorite. Some rutile and epidote occur with the chlorite.

The light-colored constituents are plagioclase and some quartz. In the fine-grained dikes plagioclase occurs as slender laths, whereas in the mediumgrained rock plagioclase crystals are stocky (for example, loc. 1841). Epidote is abundant as an alteration product of plagioclase. Magnetite, sphene, and apatite are the accessories.
A sill-like body near the northern border of plate 1 (loc. 1912) consists of coarse-grained hornblende gabbro, in which euhedral to subhedral prisms $(1 / 2-11 / 2 \mathrm{~cm}$ long) of hornblende are oriented at random and plagioclase fills the interstices. The hornblende is a brown basaltic variety, and some chlorite and epidote occur next to and within the hornblende. Outlines of a few chlorite-epidote clusters suggest that they may be alteration products of augite. Lath-shaped albite crystals are twinned according to albite, Carlsbad, and complex laws. Many albite crystals have abundant epidote in their centers and additional epidote fills some of the interstices. Other interstices are filled by granophyric intergrowth of quartz and albite, or by quartz and orthoclase. Apatite forms slender prisms that traverse the grains. Skeletal grains of ilmenite accompanied by leucoxene are common. This gabbro resembles the pyroxene gabbro described earlier except that hornblende tends to be better formed and augite is lacking.

\section{PLAGIOCLASE PORPHYRY}

Plagioclase porphyry dikes with euhedral plagioclase and quartz phenocrysts in a dark-gray fine-grained groundmass are widespread (fig. 27A). The composition of these dikes is tonalitic. Plagioclase and quartz phenocrysts constitute about 10 percent of the rock; the groundmass consists mainly of small brown euhedral hornblende prisms and plagioclase laths. Orthoclase, chlorite, magnetite, sphene, and apatite are additional constituents. Small grains of epidote occur as an alteration product in plagioclase. The groundmass is mineralogically and texturally close to that of the porphyritic hornblende gabbro dikes.

Aphanitic dikes of tonalitic composition occur, for example in locality 567. These dikes are dark gray and contain only a few small phenocrysts of quartz and plagioclase. The groundmass consists of tiny lath-shaped plagioclase crystals and interstitial quartz, biotite, and hornblende. Magnetite, calcite, and a few tiny grains of epidote occur with the dark constituents.

\section{GRANITE PORPHYRY}

Classed as granite porphyry are all light-colored silicic dikes in which the major constituents are quartz, plagioclase, and orthoclase. The amount of orthoclase in many is less than in common granite. The composition of these dikes is close to that of quartz monzonite except that the amount of orthoclase is less.

The common granite porphyry is a light-brown or light- to medium-gray rock with phenocrysts of quartz and plagioclase. The phenocrysts constitute from 10 


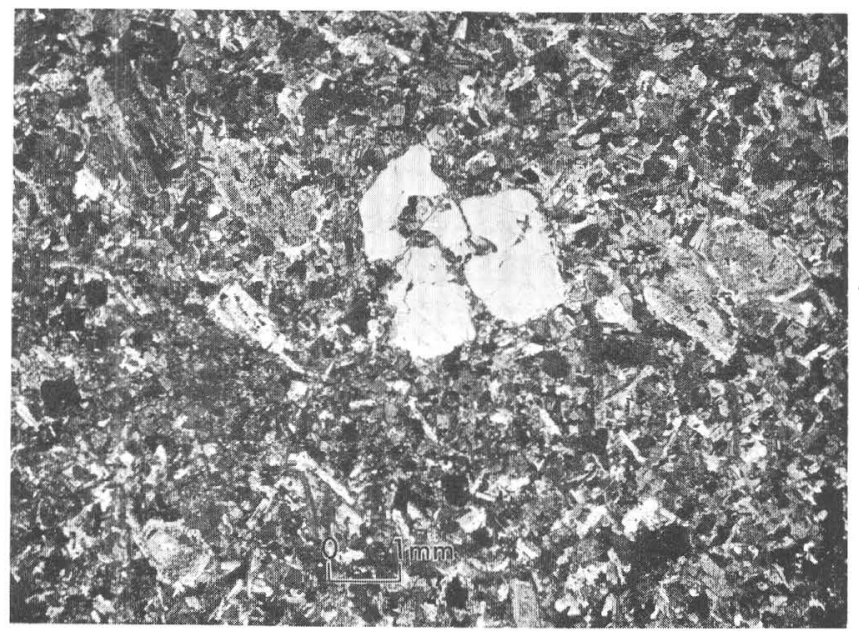

A. Quartz and plagioclase phenocrysts in a dioritic dike along Merry Creek, 4 miles northeast of Clarkia (loc. 1630). The groundmass consists mainly of tiny euhedral hornblende prisms and plagioclase laths. Crossed nicols.

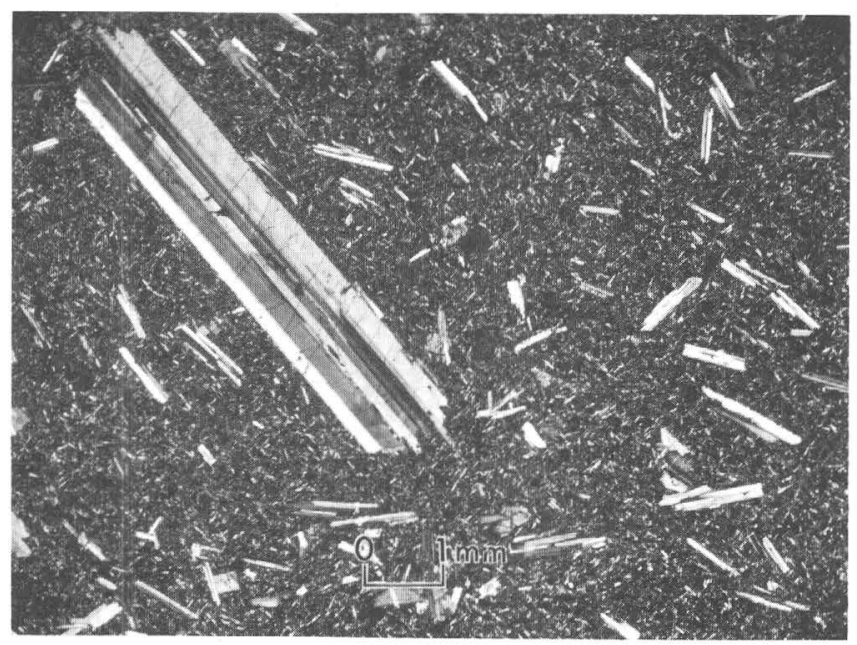

$B$. Columbia River basalt along Merry Creek, 1 mile northeast of Clarkia (loc. 1623). A few larger phenocrysts of labradorite occur in the porphyritic basalt; small phenocrysts of labradorite abound. Crossed nicols.

FIGURE 27.-PHOTOMICROGRAPHS OF PLAGIOCLASE PORPHYRY AND COLUMBIA RIVER BASALT.

to 50 percent of the rock; the individual grains range from 3 to $10 \mathrm{~mm}$ in diameter. In some outcrops phenocrysts of quartz are euhedral, with pyramidal faces; but in the other outcrops, both the quartz and the plagioclase phenocrysts are subhedral. In most dikes the amount of plagioclase phenocrysts exceeds that of quartz phenocrysts. Phenocrysts of hornblende and biotite, or only biotite, occur also, but always in subordinate amounts.

The fine grained groundmass consists of quartz, plagioclase, orthoclase, biotite, hornblende and some sphene, apatite, and zircon. In some dikes, chlorite, sericite, calcite, and epidote occur as alteration prod- ucts. In the very light colored dikes, biotite is the only dark constituent. Alteration of biotite into chlorite with inclusions of epidote, sphene, and rutile is common.

A gray porphyritic dike that is exposed along Stony Creek about 2 miles west of the mouth of Glover Creek differs in many respects from the common type described above. This dike contains numerous phenocrysts of perthitic orthoclase but none of quartz. Groups of three or four anhedral pinkish-white orthoclase crystals and elongated groups and shreds of small dark hornblende and biotite grains contrast with the fine-grained steel-gray groundmass. All larger phenocrysts are orthoclase and only a few small phenocrysts are albitic plagioclase. The groundmass is sheared and consists of quartz, plagioclase, orthoclase, hornblende, and biotite.

Granite porphyry dikes, which are extremely common along the fault zones, were probably emplaced over a considerable time interval; some of the dikes are brecciated and the fractures are filled with pegmatite (fig. 28).

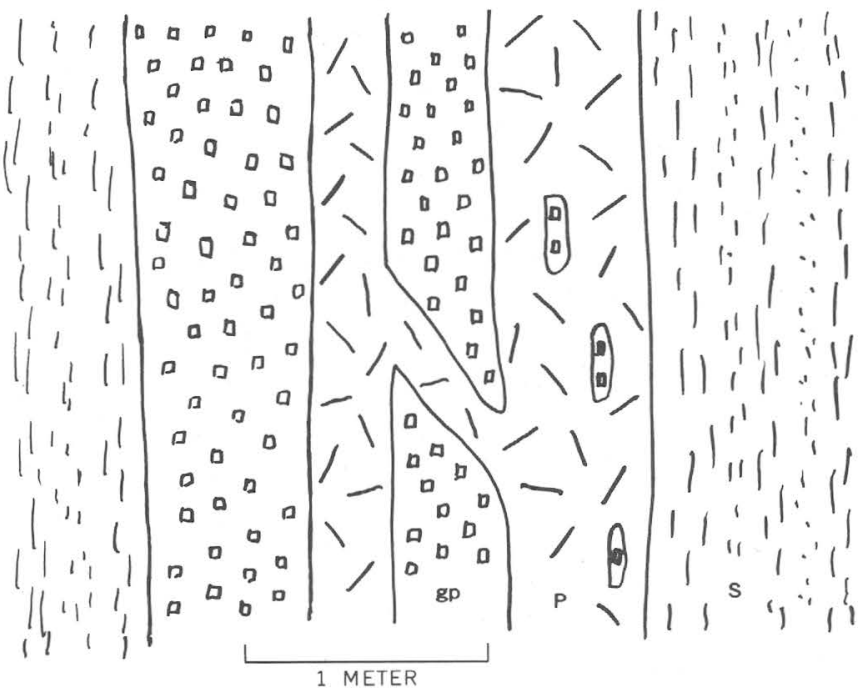

FIGURE 28.-Granite porphyry (gp) dike cut by pegmatite $(P)$ in a schist (S) along a small dirt road leading from Elk Creek to the East Fork of Potlatch Creek, about 5 miles north of Elk River (loc. 1190, 1 mile west of Elk Creek)

\section{COLUMBIA RIVER BASALT}

The basalt in the southern part of the mapped area belongs to the eastern margin of the Columbia River plateau. The basalt in the northwestern part is the southernmost remnant of the basalt cover that extends along the St. Maries River valley from Coeur d'Alene Lake (28 miles to the northwest of the northwest corner of pl. 1) to Clarkia. Only one flow with columnar jointing is exposed in the river valley near Clarkia, whereas several flows, each ranging about 8 
to 20 meters in thickness, occur along the canyons of Elk Creek and its tributaries in the southwest. The total thickness of the basalt in these canyons is as much as 300 meters.

The basalt is an aphanitic or fine-grained dark rock with abundant vesicles in the upper and lower parts of the flows. Columnar jointing is prominent in many flows, but some others break into irregular-shaped polygonal blocks.

Numerous slender laths of plagioclase oriented at random are visible in most outcrops. Thin sections show that the major constituents are labradorite and augite with interstitial brown glass and abundant magnetite and ilmenite. In the very fine grained basalt plagioclase phenocrysts are fewer (fig. $27 B$ ) and the groundmass in fine grained and porphyritic, consisting of augite and tiny plagioclase laths. In the coarser grained variety, plagioclase phenocrysts constitute 35 to 45 percent of the rock, 40 to 45 percent being augite and the rest interstitial brown glass, green celadonite, magnetite, ilmenite, and olivine.

\section{GRANITIZATION AND MIGMATIZATION}

Only a minor part of the schist and biotite gneiss next to the granitic bodies and to the largest quartz diorite stock has been transformed to gneissic rocks in which the amount of plagioclase and orthoclase is increased enough to give the contact zone a granitic or migmatitic appearance and composition. Most of the granite next to the quartz diorite stock north of Elk River (pl. 1) is gneissic, has gradational contacts with the schist, and was probably formed by granitization. Elsewhere the grantitized parts of the schist and biotite gneiss range only from a few meters to about $10 \mathrm{~m}$ in thickness and extend from $1 / 4$ to 2 miles in length.

Pegmatitic and granitic veins and dikes abound in metasedimentary rocks near some plutonic rocks, giving rise to rocks that in their general appearance resemble contact migmatites (for example, figs. 25 and 26). These veins are especially abundant in the biotite gneiss between the two largest intrusive bodies. There are at least two generations of pegmatitic veins and dikes: one earlier than the granite and one later. The granitic veins and dikes contain inclusions of schist and dark fine-grained dioritic rock. Minerals in the granite are oriented at random and the texture is hypidiomorphic. Thus these veins and dikes have textures and structures typical of igneous rocks and probably represent offshoots of the same magna from which pink granite belonging to the quartz monzonite series crystallized.

Granitized sillimanite-mica schist in the vicinity of the quartz diorite stock crops out along a dirt road leading from Hemlock Butte to the East Fork of Potlatch Creek, about 1 mile west of Hemlock Butte (loc. 1431). The granite is fine grained and pink, similar to that in dikes and veins (fig. 26). Small inclusions of kyanite-biotite schist in every stage of digestion are distributed throughout the small occurrence of this granite (fig. 29).

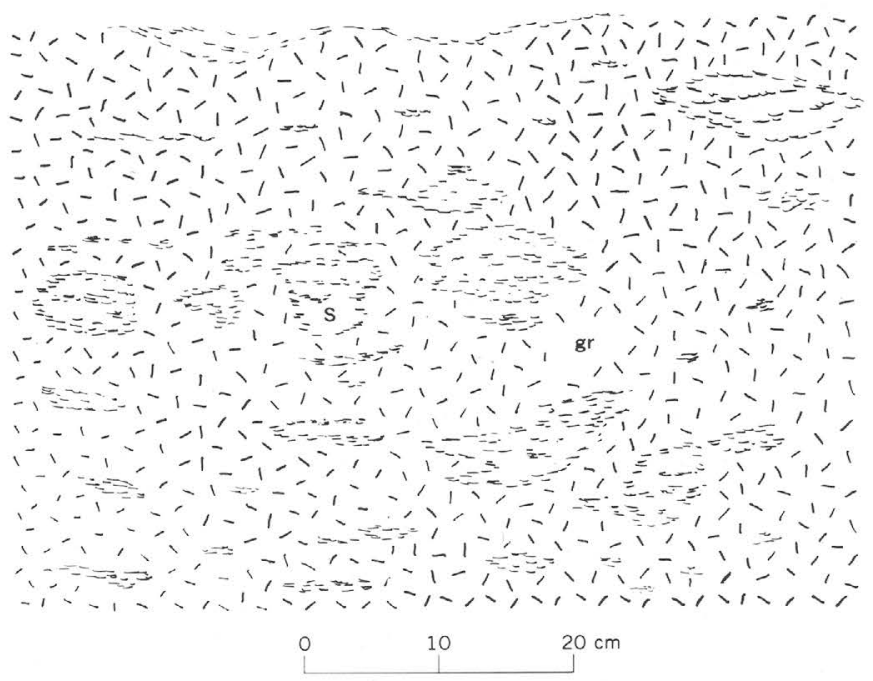

FIGURE 29,-Remnants of kyanite-sillimanite-biotite-muscovite schist (S) in fine-grained gray granite (gr), along a road leading from Hemlock Butte to the East Fork of Potlatch Creek, about 1 mile west from Hemlock Butte.

The granite along the southern contact of the quartz diorite stock is coarse grained, has a distinctly foliated texture, and contains biotite-rich schlieren and ghostlike remnants of biotite-muscovite schist, giving an impression that it was formed by granitization of the schist.

Much of the coarse-grained granodioritic gneiss in the northeastern part of the area is a result of secondary crystallization of plagioclase $\left(\mathrm{An}_{20}\right)$ and hornblende in the schist, in which the amount of quartz is therefore less than in the normal schist. These gneissic rocks abound in the southern part of T. $43 \mathrm{~N}$., R. 3 E., south of Gold Center Creek, and in the northern part of T. 42 N., R. 3 E., north of Glover Creek, where small bodies of gray granite and quartz diorite occur. The granodioritic gneiss is a light-gray medium- to coarse-grained rock, made mainly of easily recognized plagioclase $\left(\mathrm{An}_{20}\right)$, quartz, hornblende, and biotite. In addition to these major constituents, there are interstitial orthoclase, anhedral grains of epidote, euhedral to subhedral crystals of sphene, and small prisms of apatite. A few small crystals of zircon are included in biotite and in hornblende. Hornblende occurs in small anhedral elongated grains that have 
their longest dimensions ( $c$ or $b$ axis) parallel to the plane of foliation and show pleochroism $Z=$ green, $Y=$ light green, $\mathrm{X}=$ yellowish green. Biotite flakes are of the same size as the hornblende crystals (1-3 mm long) and oriented with their cleavage subparallel to the plane of foliation (fig. $23 B$ ). Tiny grains of hornblende and biotite occur next to the larger grains of these minerals and along the plane of foliation between the larger grains. The texture and mode of occurrence of these gneisses resemble those of the metasomatic tonalites described from the Orofino area (Hietanen, 1962); and most likely also these bodies are a result of introduction of the elements (sodium, calcium, iron, magnesium) that together with the silicon and aluminum of the metamorphic rocks formed feldspars and hornblende.

In some of the gneissic rocks, biotite is the only dark-colored constituent, and the composition is close to that of the granite. However, the amount of potassium feldspar is less than in the normal granite. These rocks grade to garnet-biotite-muscovite schist and were formed by development of abundant oligoclase and some orthoclase in the schist near the granitic and dioritic bodies.

\section{DISTRIBUTION OF METAMORPHIC FACIES IN SPACE AND TIME}

The sequence of crystallization of the three aluminum silicates-andalusite, kyanite, and sillimanitein the schists around Clarkia yield some information about the distribution of the pressure and temperature fields during the recrystallization. The square cross sections of crystal aggregates of muscovite that are seen on the bedding planes of the schist in some localities west of Clarkia are most likely pseudomorphs after andalusite. Their occurrence would suggest that andalusite crystallized early, but became unstable. Also the nodules of kyanite and muscovite in the schists east and southeast of Clarkia and those of kyanite and sillimanite near Hemlock Butte could be pseudomorphs after andalusite. Because andalusite is stable at fairly high temperatures, but only at low pressures, it is likely that an increase in pressure was the major reason for its disappearance and change to kyanite.

West of Clarkia, sillimanite is found as a pseudomorph after kyanite, as for instance, on Bechtel Mountain. This change suggests a local rise in the temperature after the crystallization of kyanite. The local rise in temperature may be due to an intrusive body not exposed in the area of plate 1 . Toward the south the sillimanite becomes prevalent around Hemlock Butte. During the metamorphism, the tempera- ture and pressure near Clarkia moved from the stability field of andalusite, first to the stability field of kyanite then to the border line that separates the stability fields of kyanite and sillimanite (Hietanen, 1956, fig. 5 and $1961 b$, fig. 3). These inversions between the three aluminum silicates indicate that the gradual increase in the degree of metamorphism toward the south is not simple contact metamorphism along the border zone of the huge Idaho batholith, but is complicated by factors other than regular and gradual change in temperature. The order of recrystallization near Clarkia and the pseudomorphs after andalusite and kyanite suggest that there was first an increase in pressure and later an increase in temperature. The orientation of the micaceous minerals and the hornblende parallel to the planes that served as glide planes during the deformation suggests that the crystallization of these minerals took place in a field of stress, most likely during the deformation and under moderate pressure. The occurrence of kyanite crystals along the most prominent $s$ plane (the bedding) suggests that the kyanite crystallized during this same phase under high pressure and approximately at the same temperature. Andalusite crystallized earlier at a somewhat lower pressure but probably at about the same (moderate) temperature. On the other hand, the crystallization of sillimanite at the expense of kyanite indicates a rise in temperature. Thus three major steps can be separated in the sequence of events near Clarkia:

1. Folding and recrystallization at moderate temperature and pressure. Crystallization of andalusite, muscovite, biotite, and almandite in the schists, and of hornblende, epidote, and plagioclase $\left(\mathrm{An}_{5-20}\right)$ in the calcareous layers, suggesting conditions of the epidote-amphibolite facies.

2. Increase in pressure and probably slight increase also in temperature to correspond to the conditions of the higher part of the epidote-amphibolite facies. Crystallization of kyanite at the expense of andalusite, formation of staurolite in the schists, and crystallization of diopside and plagioclase $\left(\mathrm{An}_{10-25}\right)$ instead of (or with) hornblende and epidote in the calcareous layers.

3. Increase in temperature to correspond to the lower part of the amphibolite facies. Crystallization of sillimanite at the expense of kyanite. Increase in size of minerals such as garnet, biotite, muscovite, diopside, plagioclase, and quartz.

These three phases of recrystallization can be correlated with the major geologic events in the area as follows: 
In phase 1 , the rocks of the Belt series were folded and metamorphosed during the Nevadan orogeny. Small intrusive bodies of gabbro and quartz diorite were emplaced during the folding. These bodies are more common in a zone closer to the Idaho batholith (Hietanen, 1962) than in the present area, which indicates that the place now occupied by the Idaho batholith was a center of heat and intrusive activity during Nevadan time.

The region around Clarkia lies about 30 miles northwest of the border of the Idaho batholith, and it would take some time (probably millions of years) for the heat to travel this distance in rocks 15 to $20 \mathrm{~km}$ below the surface, whereas the pressure would be transmitted practically instantaneously. It would, therefore, be only logical to assume that some high temperature (and antistress) minerals would crystallize after the main dynamic phase in the course of regional metamorphism. Near Clarkia andalusite was one of the early high-temperature (but antistress) minerals.

Phases 2 and 3 are most likely connected with the intrusion of the border zone of the Idaho batholith. Phase 3 represents the heat wave that lagged behind

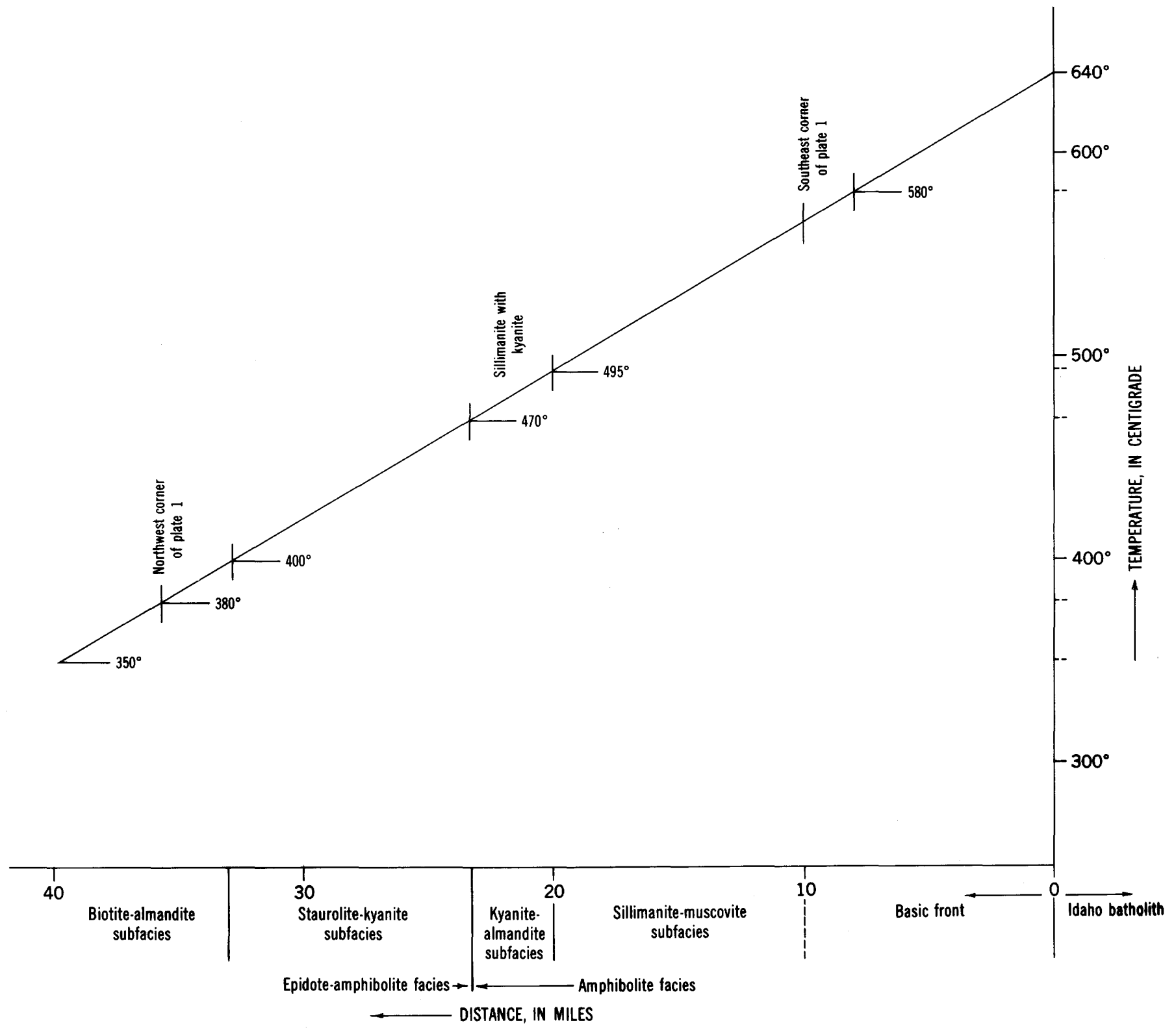

Figurn 30.-Hypothetical curve for the temperature of recrystallization in various metamorphic facies. Abscissa is the horizontal distance in miles from the border of the Idaho batholith. The end temperatures are those assumed for the green schist facies and for the beginning of the melting of granite. See further explanation in the text. 
the accelerated pressure. Again the interval between the times when the maximum pressure and the maximum temperature were reached near Clarkia may have been of the order of millions of years, long enough for the crystallization of kyanite before the temperature field of sillimanite was reached. In the course of recrystallization, the temperature and pressure approached the triple point of the three aluminum silicates but never reached it as they did in the neighboring Boehls Butte quadrangle (Hietanen, 1956). As long as the temperature and pressure of this triple point in the map area is not known, other mineral associations must be used in estimating the temperature and pressure of recrystallization.

In the high-temperature zones of the regionally metamorphosed pelitic schist, muscovite (+quartz) normally yields microcline and sillimanite; this reaction, together with the disappearance of kyanite, theoretically marks the lower limit of the sillimanite subfacies. In the Elk River-Clarkia area, the occurrence of muscovite persists into the sillimanite subfacies, and farther southward up to the border zone of the batholith. Its quantity, however, is greatly reduced in the zone next to the batholith.

The association of muscovite with sillimanite shows that the metamorphic temperatures in the southernmost part were lower than $650^{\circ} \mathrm{C}$ (Yoder and Eugster, 1955). Furthermore, the melting point of granite, which according to Tuttle and Bowen $(1958$, p. 122$)$ is $640^{\circ} \mathrm{C}$ at depth of about $20 \mathrm{~km}$, was not reached closer than 8 miles southeast of the southeastern corner of the Elk River-Clarkia area, perhaps still farther because the border zone of the batholith was emplaced by intrusion and the zone of remelting would have been either under the level exposed or farther toward the center of the batholith. The grade of metamorphism decreases northward, and the southern border of the green schist facies is about 10 miles north of Clarkia. If the temperature of this limit is assumed to be about $350^{\circ} \mathrm{C}$, temperature at the contact of the batholith $640^{\circ} \mathrm{C}$, and the increase of temperature toward the batholith more or less linear, the graph in figure 30 gives a rough estimate of the temperatures in each facies. The temperature would increase from $380^{\circ}$ to $580^{\circ} \mathrm{C}$ from the northern border to the southern border. Staurolite would be stable with $\mathrm{ky}$ anite between $400^{\circ}$ and $470^{\circ} \mathrm{C}$. Sillimanite would start to crystallize at about $470^{\circ} \mathrm{C}$ but become the only stable form of $\mathrm{Al}_{2} \mathrm{SiO}_{5}$ at about $500^{\circ} \mathrm{C}$. The actual temperature interval was most likely less and the curve should be flatter in this central part, or the zone where sillimanite and kyanite occur together should be narrower.

\section{DISTRIBUTION OF POTASSIUM FELDSPAR}

The abundance of the potassium feldspar in the gneissic layers in the northern and central part of the area and its scarcity in the corresponding layers in the southern part has three possible explanations: (1) distribution of potassium is due to original deposition, (2) the abundance of microcline in the northern part is due to metasomatic introduction of potassium, (3) the scarcity of microcline in the southern part is a result of removal of potassium during metasomatic metamorphism.

No evidence decisively favoring one of these possibilities has been found in the field or under the microscope. Moreover, an acceptable explanation has to agree not only with the facts in the present area, but also with facts and conclusions reached in neighboring areas. In the following discussion, the three possibilities are therefore weighed in the light of local and regional evidence.

1. Lateral variation in the composition of individual units is fairly common in the Belt series. For example, in the Boehls Butte quadrangle abundant calcareous material occurs in the Prichard formation in the stratum which, just north of this quadrangle, consists of fairly pure quartzite (Hietanen, 1963). This facies change takes place by gradual increase of the number and the thickness of the calcareous layers, and by decrease of quartzitic material. In the Elk River-Clarkia area, the change from gneisses rich in potassium feldspar to those in which this mineral is scarce or lacking takes place in a similar way; the number and thickness of the potassium-rich layers decrease from the vicinity of Elk Butte toward the south over a distance of about 10 miles. Most of the potassium-rich layers contain, in addition to microcline, abundant biotite or biotite and muscovite. In many outcrops of diopside or biotite gneiss the potassiumrich layers (1 to $3 \mathrm{~mm}$ thick) are well defined and persist over tens of meters. Microcline in these layers occurs as small irregular-shaped or rounded grains in association with quartz and micas. This mode of occurrence suggests that microcline crystallized from the clastic grains of the original sedimentary material. Abundance of micas in the microcline-rich layers indicates that these layers were originally clays rich in potassium. It is well known that clays are capable of absorbing potassium and that potassium-bearing authigenic clay minerals, such as illite, are formed early during weathering and sedimentation (Grim, 1953).

2. Extensive metasomatism is known in the area adjoining the Elk River-Clarkia area to the south and southeast (Hietanen, 1962). It involves introduction 
of sodium, calcium, aluminum, iron, and magnesium and removal of potassium and silicon. The hypothesis that the potassium removed from the zone next to the Idaho batholith might have been deposited in the outer contact zone of the batholith is very entertaining, but the potassium-rich gneisses have many features that speak against such an interpretation. First; the textures and structures of the microcline-bearing gneisses indicate that all minerals in them crystallized more or less contemporaneously from the material present in each layer. There are none of the textures typical of the metasomatic minerals in the Boehls Butte quadrangle, in the Headquarters quadrangle, or near Dent. In these areas, the metasomatic minerals occur as large, round, or more rarely euhedral grains, include other minerals, and have a rather irregular distibution that cuts in many places acoss the bedding. In contrast, the potassium feldspar in the gneisses near Elk River and Clarkia is confined to certain thin beds and laminae, where it occurs in small irregularly-shaped grains in association with quartz, biotite, diopside, and plagioclase. The bedding is extremely well preserved and the thin (1-3 $\mathrm{mm}$ ) potassium-rich beds persist over several tens or even hundreds of meters just as do the paper-thin micaceous laminae. Therefore it does not seem likely that potassium was introduced metasomatically; rather the occurrence of potassium feldspar is comparable to that of the other potassium-bearing minerals, biotite and muscovite, which crystallized within thin welldefined potassium-rich clayey layers interbedded with calcareous sandstone.

3. The third explanation is postulated upon the following concept: during sedimentation potassium was equally distributed over the whole area but that later, during metasomatic metamorphism, it was removed from the southern part of the area. This southern part is next to the inner contact zone of the Idaho batholith from which, as described in an earlier paper (Hietanen, 1962) potassium and silicon were removed and sodium, calcium, aluminum, iron, and magnesium were introduced. The textures and structures suggest that more intensive recrystallization took place in this southern part than in the northern part. In the southern part, grain size is larger and the beds are not as well defined. However, typical metasomatic textures and structures as defined under explanation 2 are rare. Large albitic plagioclase grains that contain numerous small round quartz inclusions and that could be secondary were found only in one specimen. This specimen was collected along the North Fork of Clearwater River in the extreme southeast corner of the mapped area, thus close to the metasomatized inner contact zone of the Idaho batholith. Elsewhere the lightcolored constituents occur as irregularly-shaped grains of about equal size and the micas are well alined parallel to the bedding or parallel partly to the bedding and partly to the transecting cleavage. In a few localities, secondary hornblende occurs in diopside gneisses, indicating addition mainly of hydrous molecule. The number and thickness of quartz-rich layers in the diopside-plagioclase gneiss is larger than that in the corresponding gneisses next to the batholith. This change, too, can be either original or due to the removal of silicon from the zone next to the batholith. In many localities, bedding has been obscured by recrystallization; but there are no distinct signs of largescale removal of potassium, and it must be concluded that if such removal occurred, it must have been during an early phase of recrystallization.

All diopside gneiss exposed in the southern part of the Elk River-Clarkia area belongs to the lower quartzite-gneiss unit of the Wallace formation. In the northern part, the white granular quartzite, which rarely contains potassium feldspar, is the major rock type of this unit. The biotite and hornblende gneisses bearing potassium feldspar are a minor portion of the rock unit. Southward, the amount of tremolite-actinolite and diopside increases, but fairly pure white granular beds crop out again along the North Fork of Clearwater River. It seems, therefore, that the diopside-plagioclase gneisses between Elk Butte and Little Green Mountain include beds that are dolomitic equivalents of the white granular quartzite. In this part of the area, layers rich in potassium feldspar probably are rare because the original sediment was poor in potassium. It is more difficult to understand why the biotite gneiss layers of the southern part are poor in potassium feldspar whereas the corresponding layers in the northern part contain a considerable amount of microcline.

In summary, the following facts support a sedimentary explanation for the distribution of potassium: (a) Potassium feldspar is more abundant in the upper than in the lower quartzite-gneiss unit. (b) Potassium feldspar occurs only in the biotite gneisses and biotite-bearing diopside gneisses. (c) Potassium minerals are confined to thin layers that persist over long distances, in a distribution comparable with that of the biotite laminae, which crystallized from sedimentary material. (d) Potassium feldspar occurs as irregular-shaped or rounded grains that are of the same size as quartz and plagioclase and lack replacement textures.

Because the textures and structures of the gneisses in the northern part of the Elk River-Clarkia area 
fail to indicate any metasomatic addition of potassium, it is concluded that microcline crystallized there at the expense of sedimentary material. It remains to decide whether or not potassium-rich layers were equally deposited in the southern part; if they were, the lack of potassium feldspar is presumably due to metasomatic removal of potassium.

The fact that potassium feldspar is rare in all rocks near the Idaho batholith, whereas layers rich in this mineral occur in increasing numbers in the corresponding layers outside the contact zone, supports the possibility of metasomatic removal and deserves careful consideration.

The changes in grade of metamorphism and in the distribution of potassium are regular over the whole area and are not related to the small intrusive bodies exposed in the central part. Because the grade of metamorphism increases fairly regularly toward the southeast, it was concluded that the metamorphism is connected with the intrusive activity of the main mass of the Idaho batholith, the nearest outcrops of which are exposed about 10 miles southeast of the North Fork of the Clearwater River. Irregularly shaped parts of all rocks within this 10-mile-wide inner contact zone show metasomatic alteration in which silicon and potassium were removed and sodium, calcium, aluminum, iron, and magnesium introduced (Hietanen, 1962).

The unaltered parts of the strata in this inner contact zone are mineralogically very similar to the corresponding layers in the southern part of the Elk River-Clarkia area. Also, potassium feldspar is scarce or lacking. The removal of potassium from the inner contact zone is connected with the late replacement of biotite by hornblende. Such a replacement is rare in the southern part of the Elk RiverClarkia area, which represents the outer contact zone of the Idaho batholith. It is possible, however, that a part of the potassium was removed from this outer contact zone during an early phase of metamorphism.

\section{ELK RIVER-CLARKIA AREA AS A PART OF THE OUTER CONTACT ZONE OF THE IDAHO BATHOLITH}

The rocks exposed in the northern part of the Elk River-Clarkia area represent isochemically metamorphosed equivalents of the Belt series in the Coeur d'Alene district. Changes in composition and local changes in texture occur from north to south. The major compositional difference between the rocks of the Belt series in the northern and southern parts is the lack of potassium feldspar in the southern part. The mineral assemblages of the metasedimentary rocks indicate a steady increase in metamorphic temperatures and pressures toward the south. In the northernmost part, recrystallization took place under conditions of the biotite-almandite subfacies of the epidote-amphibolite facies. In the central part, the mineral assemblages are those common in the staurolite-kyanite subfacies of the epidote-amphibolite facies; in the southern part, those of the sillimanitemuscovite subfacies of the amphibolite facies.

The structural continuation of the Belt series toward the south and the east from the Elk River-Clarkia area have been studied earlier (Hietanen, 1962, and 1963). Comparison of the mineral content and the texture of the schist and gneiss in the Elk RiverClarkia area with those of the corresponding layers in the Wallace and the Prichard formations south and east of this area indicates that the grade of metamorphism continues to increase toward the south and the east of the area shown in plate 1. A greater change, however, is caused by extensive metasomatic introduction of sodium, calcium, aluminum, iron, and magnesium in a zone next to the Idaho batholith (Hietanen, 1962) and by introduction of sodium and possibly aluminum into the schist in the Boehls Butte quadrangle and vicinity (Hietanen, 1963). Traces of similar metasomatic action appear in only a few localities in the southern and eastern parts of the Elk River-Clarkia area, where the rocks of the Belt series have suffered the same grade of metamorphism as those next to the batholith.

Granitization connected with the intrusive stocks has affected small local parts of the strata (about 1 percent), whereas most of the rocks of sedimentary origin were recrystallized without any determinable addition of material from outside sources (isochemical metamorphism). Most of the igneous stocks were emplaced by mechanical intrusion and the rocks that resulted from reaction between the igneous and the metasedimentary material form only a small proportion of the total amount of plutonic rocks.

The regional metamorphism is clearly connected with the history of the formation of the Idaho batholith as pointed out in the preceding chapter. The major rock types in the batholith are quartz diorite, granite, and quartz monzonite. The marginal zone consists of quartz diorite devoid of potassium feldspar. The center consists mainly of quartz monzonite rocks rich in orthoclase. The composition of the quartz diorite is similar to the mean composition of the surrounding metasedimentary rocks; but the central part is considerably richer in alkalies, especially in potassium.

If it is assumed that the granitoid rocks of the batholith are a result of granitization and partial remelting of the metasedimentary rocks which in composition 
were similar to those around the batholith, considerable amounts of iron (about 3 percent), magnesium ( 2 percent), and calcium ( 3 percent) should have been removed and mainly silicon (5 percent), sodium (2 percent), and potassium ( 3 percent) introduced into the place now occupied by the granitoid rocks (Hietanen, 1962, table 31). If the granitized metasedimentary rocks contained more potassium-resembling the strata that are exposed in the northern part of the Elk River-Clarkia area-the amount of silicon and potassium needed to transform the strata into granite would be somewhat less, perhaps only 3 and 2 percent respectively, but still qualitatively the same.

A part of the potassium and silicon needed for the formation of the quartz monzonitic batholith was most likely derived from the surrounding metasedimentary rocks, which were consequently impoverished in these elements and relatively enriched in calcium, iron, and magnesium. Later, during the intrusion of quartz diorite more potassium and silicon may have joined the magmas; cafemic constituents migrated in an opposite direction and became fixed in the marginal zone of the botholith and in the metasedimentary rocks along the contact as decribed earlier (Hietanen, 1962). As a result of this migration, a zone of enrichment of basic components, 10 to 20 miles wide, was formed northwest of the batholith. The southern part of the Elk River-Clarkia area adjoins this basified zone in the south. There was no large-scale addition of calcium, iron, or magnesium in this outer contact zone, but the lack of potassium feldspar is conspicuous. Considering the higher mobility of potassium in comparison with calcium, iron, and magnesium, it seems very likely that the potassium could have been mobilized and removed within a wider zone than the other elements. The direction of its migration would have been the same as in the inner contact zone - that is, toward the growing batholith. The general increase in the amount of plagioclase toward the batholith suggests that sodium replaced potassium along the outer contact zone.

\section{REFERENCES CITED}

Anderson, A. L., 1930, The geology and mineral resources of the region about Orofino, Idaho: Idaho Bur. Mines and Geology Pamph. 34, 63 p.

Barth, T. F. W., 1936, Structural and petrologic studies in Dutchess County, New York; pt. 2-Petrology and metamorphism of the Palezoic rocks: Geol. Soc. America Bull., v. 47, p. 775-850.

1952, Theoretical petrology: New York, John Wiley and Sons, $387 \mathrm{p}$.
Beskow, Gunnar, 1929, Södra Storfjället im südlichen Lappland: Sveriges Geol. Undersökning, Ser. C, No. 350, 334 p.

Eardley, A. J., 1951, Structural geology of North America: New York, Harper and Bros., 624 p.

Eskola, Pentti, 1015, Om sambandet mellan kemisk och mineralogisk sammansättning hos Orijärvitraktens metamorfa bergarter: Comm. Geol. Finlande, Bull. 44, $145 \mathrm{p}$.

1939, Die metamorphen Gesteine, p. 263-407 in Barth, T. F. W., Correns, C. W., and Eskola, P., Die Entstehung der Gesteine: Berlin, Springer, $422 \mathrm{p}$.

Fyfe, W. S., Turner, F. J., and Verhoogen, J., 1958, Metamorphic reactions and metamorphic facies: Geol. Soc. America Mem. 73, 259 p.

Grim, R. E., 1953, Clay mineralogy: New York, MeGrawHill Book Co., 384 p.

Hallimond, A. F., 1943, On the graphical representation of the calciferous amphiboles: Am. Mineralogist, v. 28, p. 65-89.

Hietanen, Anna, 1956, Kyanite, andalusite, and sillimanite in the schist in Boehls Butte quadrangle, Idaho: Am. Mineralogist, v. 41, p. 1-27.

- 1961a, Superposed deformations northwest of the Idaho batholith, Internat. Geol. Cong., 21st, Copenhagen 1960, Proc. Pt. 26, p. 87-102.

$-1961 \mathrm{~b}$, Metamorphic facies and style of folding in the Belt Series northwest of the Idaho batholith : Bull. Comm. Geol. Finlande, v. 196, p. 73-103.

- 1962, Metasomatic metamorphism in western Clearwater County, Idaho: U.S. Geol. Survey Prof. Paper 344-A, p. 1-116.

1963, Anorthosite and associated rocks in Boehls Butte quadrangle and vicinity, Idaho: U.S. Geol. Survey Prof. Paper 344-B. (In press.)

Kulling, Oskar, 1933, Bergbyggnaden inom BjörkvattnetVirisen området i Västerblottensfjällens centrala del : Geol. Fören, Stockholm Förh., No. 393, v. 55, H. 2, p. 167-422.

Pardee, J. T., 1911, Geology and mineralization of the upper St. Joe River basin, Idaho: U.S. Geol. Survey Bull. 470, p. 39-61.

Rabbitt, J. C., 1948, A new study of the anthophyllite series: Am. Mineralogist, v. 33, p. 263-323.

Ransome, F. L., and Calkins, F. C., 1908, The geology and ore deposits of the Coeur d'Alene district, Idaho: U.S. Geol. Survey Prof. Paper 62, 203 p.

Ross, C. P., 1956, The Belt series in relation to the problems of the base of the Cambrian system, in Rodgers, J., ed., El Sistema Cambrico, su paleogeografia $y$ el problema de su base-symposium. Internat. Geol. Cong., 20th, Mexico City, 1956, Pt. 2, p. 683-699.

Shenon, P. J., and McConnel, R. H., 1939, The silver belt of the Coeur d'Alene district, Idaho: Idaho Bur. Mines and Geology Pamph. 50, 9 p.

Sriramadas, A., 1957, Diagrams for the correlation of unit cell edges and refractive indices with the chemical composition of garnets : Am. Mineralogist, v. 42, p. 294-298.

Stoll, W. C., 1950, Mica and beryl pegmatites in Idaho and Montana : U.S. Geol. Survey Prof. Paper 229, 64 p.

Thompson, J. B., Jr., 1957, The graphical anaylsis of mineral assemblages in pelitic schist: Am. Mineralogist, v. $42, \mathrm{p}$. $842-858$. 
Turner, F. J., 1948, Mineralogical and structural evolution of the metamorphic rocks: Geol. Soc. America Mem. 30, $342 \mathrm{p}$.

Turner, F. J., and Verhoogen, J., 1951, Igneous and metamorphic petrology: New York, McGraw-Hill Book Co. $602 \mathrm{p}$.

Tuttle, O. F., and Bowen, N. L., 1958, Origin of granite in the light of experimental studies in system $\mathrm{NaAlSi}_{3} \mathrm{O}_{8}-\mathrm{KAlSi}_{3}$ $\mathrm{O}_{8}-\mathrm{SiO}_{2}-\mathrm{H}_{2} \mathrm{O}$ : Geol. Soc. America Mem. 74, $153 \mathrm{p}$.

Umpleby, J. B., and Jones, E. L., 1923, Geology and ore deposits of Shoshone County, Idaho: U.S. Geol. Survey Bull. 732, $156 \mathrm{p}$.
Wagner, W. R., 1949, The geology of part of the south slope of the St. Joe Mountains, Shoshone County, Idaho: Idaho Bur. Mines and Geology Pamph. 82, p. 1-48.

Winchell, A. N., 1945, Variations in composition and properties of the calciferous amphiboles: Am. Mineralogist, v. 30, p. $27-50$.

Winchell, A. N., and Winchell, Horace, 1951, Elements of optical mineralogy-an introduction to microscopic petrography, 4th ed., Pt. 2, Description of the minerals: New York, John Wiley and Sons, $551 \mathrm{p}$.

Yoder, H. S., and Eugster, H., 1955, Synthetic and natural muscovites: Geochim. et Cosmochim. Acta, v. 8, p. 225-280. 



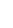


